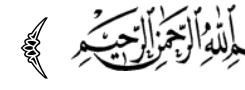

Pי

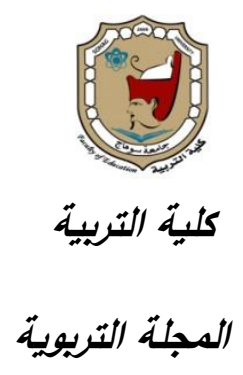

***

تصور هقترح لسد الفجوة الرقمية لدى الباحثين التربويين كمدخل لتطوير المعرفة التربوية

\title{
إعداد
}

د خديجة عبد العزيز على إبراهيه

الأستاذ المساعد بقسم أصول التربية

كلية التربية - جامعة سوهاج

المجلة التربوية ـ العلد التاسع والخمسوز ـ مارس 19.rم

Print:(ISSN 1687-2649) Online:(ISSN 2536-9091) 


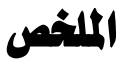

\section{أهداق الداراسة}

هافت الدراسة الحالية إلى التعرف على أهم انعكاسات العصر الرقمي على المعرفة التريوية و دواعي تطوير المعرفة التريوية في العصر الرقمي، وأهم العوامل المؤثرة على حال الباحثين التربويين ودورهم في تطوير المعرفة التريوية ، وأهم كفايات الباحثين التريويين اللازمة لتطوير المعرفة التريوية في العصر الرقمي، ومفهوم الفجوة الرقمية وأسبابها لدى ولى

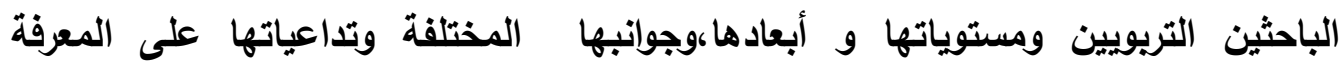
التريوية، ثم التعرف على واقع الفجوة الرقمية لاى الباحثين التريويين بمرحلة الماجستير

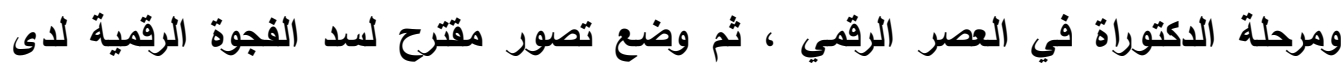
الباحثين التريويين كمدخل لتطوير المعرفة التريوية في مصر ف

\section{حلدود الثلباسة2:}

اقتصرت الدراسة على دراسة انعكاسات العصر الرقمي على المعرفة التريوية ودواعي تطويرها في العصر الرقمي، وأسباب الفجوة الرقمية لايهم ومدى وجودها لايهم ،وتم التطبيق

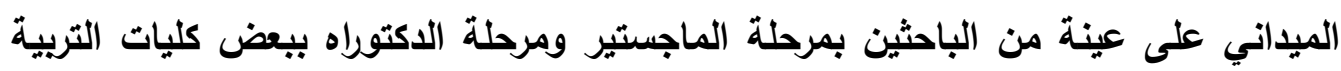

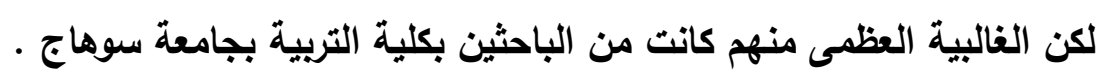

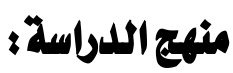
استخدمت الباحثة في هذه الاراسة المنهج الوصفي التحليلي.

\section{تثائج الداراسلة الميلداذية}

توصلت الدراسة إلى وجود فجوة رقمية لاى الباحثين التريويين ، وأن بعض جوانبها يوجد لايهم بلرجة متوسطة والبعض الآخر يوجد به ضعف شديد لكن بصفة عامة وجيه وجود فجوة البها رقمية لاى الباحثين تحتاج للعمل على القضاء عليها.

التصور المثتزح? وتم في نهاية الاراسة وضع تصوراً مقترحًا لسد الفجوة الرقمية لاى الباحثين التربويين من أجل تطوير المعرفة التريوية في مصر. 


\section{تصور مقترح لسد الفجوة الرقمية لدى الباحثين التربويين كمدخل لتطوير المعرفة التربوية.}

\section{Abstract}

\section{Objectives:}

The present study aims to highlight the most significant implications of the digital era on educational knowledge, the reasons for its development, the most significant factors affecting the situation and role of the educational researchers in developing educational knowledge, as well as their most significant competencies required for developing the educational knowledge in the digital era. It also investigates the concept, reasons, levels, dimensions, aspects, and implications of the digital divide among educational researchers and its reality among the MA. and Ph.D. candidates. The study makes a proposal to bridge the digital divide among educational researchers as an approach to developing educational knowledge.

\section{Limitations}

The study was limited to the implications of the digital era on educational knowledge and reasons for its development, extent and reasons for the digital divide, and a sample of MA. and Ph.D. candidates mostly at the Faculty of Education, Sohag University.

\section{Method}

The study utilized the descriptive and analytical approach.

\section{Results}

The study concluded that there is a digital divide among educational researchers that shall be addressed. While some of its aspects were moderate, others were very poor.

\section{Proposal}

The study makes a proposal to bridge the digital divide among educational researchers to develop educational knowledge in Egypt. 


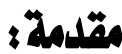

أصبح المجتمع يعيش حاليًا في عصر تسيطر عليه تكنولوجيا المطومـات والاتصالات

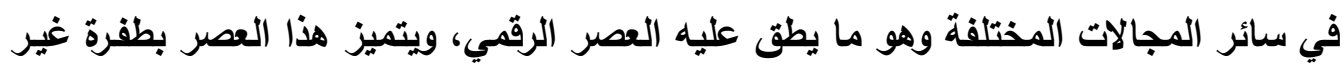

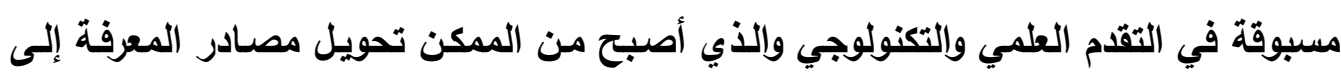
الصورة الرقمية وإتاحتها بثكل كبير مما أدى إلى التراكم المعرفي الكبير وأدى ذلك إلى تطور المعرفة في العالم المحيط بشكل كبير لم يسبق له مثيل في العصور السابقة.

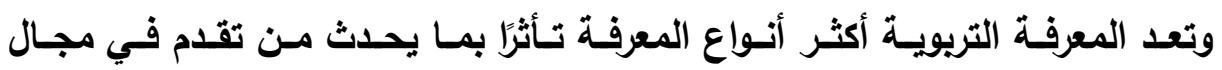

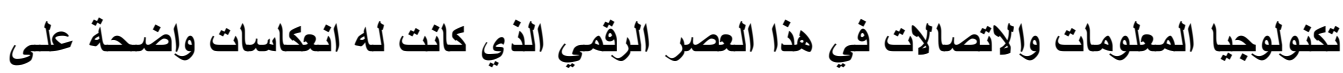

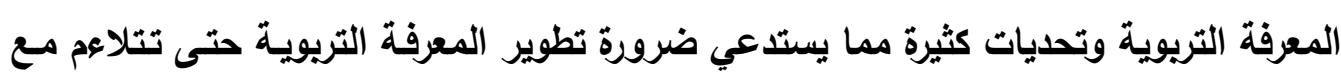
معطيات العصر الرقمي الدايث وتسهم في تنمية المجتمع وتطويره تريويًا. لأن إصلاح التربية

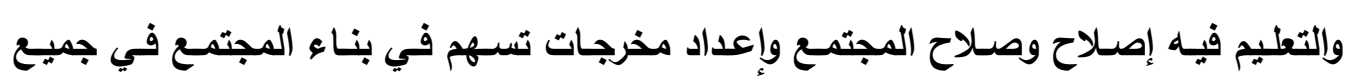

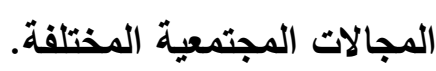

وترى دراسة (مهني غنايم، 1 ـ ـ ب)، أن الواقع التربوي في العصر الحالي أو العصر

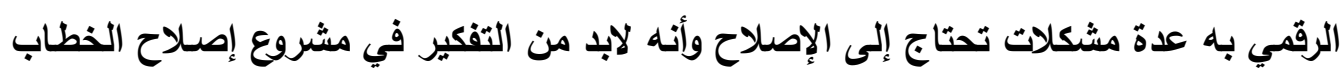

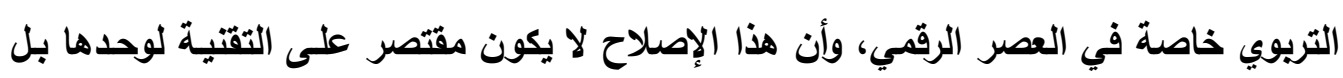
لابد من التخطيط الاستراتيجي له المنطلق من رؤية واضحة.

ويقع على كاهل الباحثين التربويين جُل الجها المطلوب لتطوير المعرفة التريوية،

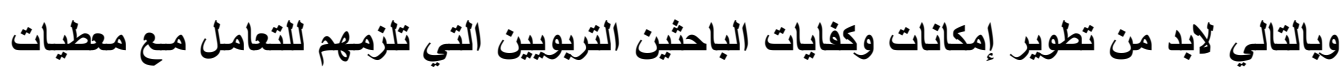
هذا العصر الرقمي وتؤدي في النهاية إلى تطوير المعرفة التريوية وذلك يستلزم الإعداد العلمي والتكنولوجي للباحثين والتـدريب المستمر على تكنولوجيا المعلومـات والاتصـالات وتوظيفها واستخداماتها في البحث التربوي حتى يستطيع الباحثون الاستفادة من معطيات العصر الرقمي 
ومما يتيحه من معرفة تريويـة عالمية ويؤدي ذلك بالباحثين إلى إنتاج معرفة تريويـة متميزة وملائمة لاحتياجات المجتمع التريوية الحقيقية ويستطيعوا كذلك نشرها وإتاحتها عبر الإنترنت وشبكاته المختلفة.

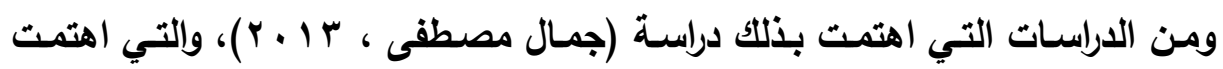

بارراسة كفايات البحث في العلوم الاجتماعية في العصر الرقمي ومن تلك الكفايات التي ترى أنها مهمة للباحث في العلوم الاجتماعية الكفايات المعرفية وإلكفايات الأدائية. و دراسة (قاطمة النجار، ه 1 ـ r)، والتي وضعت استراتيجية مقترحة لتنمية كفايات البحث العلمي لاى طلاب الدراسات العليا بصفة عامة بالجامعات المصرية في ضوء متطلبات اقتصـاد المعرفة، واهتمـت بدراسـة (مجدي المهدي، 1 ـ ب م) بالأخلاقيـات البحثيـة في زمـن الرقمية (دراسة تحليلية) حيث ترى أن المجتمع في حاجة ماسة لأخلاقيات يلتزم بها الباحثون تنظم كل ما يجري من عمليات بحثية. ويالتـالي فـإن اســطاع البـاحثون الوصـول وإلنفـاذ للمعرفـة التربويـة واســتخدامها وتوظيفها في البحث التربوي وأنتجوا معرفة تريويـة متميزة وتم نشرها وتداولها عبر الإنترنت فإنهم يصبحوا مواكبين للعصر الرقمي ومطورين للمعرفة التريوية، ولكن في حالة عدم حدوث ذلك فإنه يعني وجود فجوة رقمية لايهم.

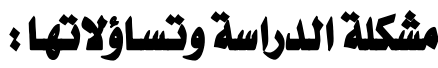

ويعد الباحثون التريويون هم عماد تطوير المعرفة التريوية في العصر الرقمي ولابد من الاهتمام بإعدادهم للألك ، " لقد أكدت تتائج عدة دراسـات تريويـة تلدي مخرجات البحث التربوي على كافة الأصعدة والتخصصات ، ونقص مهارات التعامل السليم مـع معطيات الثورة الرقميـة ممـا أدى إلى زيـادة الفجوة بين البحوث التريويـة والممارسـة الإجرائيسة لها بمختلف المستويات ، وأدركت عنهـا معظم مؤسســات البحث التريـوي أهميـة صـقل مهارات وقدرات الباحثين في التربية بطبيعة الثورة الرقمية والمعرفية والمعلوماتية "( مجدي المهدي ، 10 • ب 
إن قضية عدم مواكبة العصر الرقمي وعدم الإلمام بتكنولوجيا المعلومـات والاتصالات والاستفادة منها في الوصول للمعرفة وفي توظيفها وإنتاج معرفة تريويـة حديثة ونشرها يطلق عليـه الفجـوة الرقميـة والتـي تعد قضية كبيـرة سـعت الــول والمجتمعـات المحليـة والقوميـة والعالميـة إلى قياسـها والتعرف على حجمها و السـعى على سـدها والقضــاء عليهـا لـدى

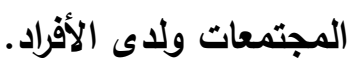
ومن أوائل الكتابات عن الفجوة الرقمية ما كتبه (نبيل على ، نادية حجازي، ه . . ب) عن الفجوة الرقميـة في الوطن العريـي في مجتمـع المعرفة بروئية عربيـة، وأوضحت مفاهيم الفجوة الرقميـة ، وأسبابها ، وأضرارها على الوطن العريـي وضرورة القضـاء عليها ويصفة خاصـة فجـوة المحتـوى العريـي الضـعيف على شبكة الإنترنت، ومـن الدراسـات التـي اهتمـت بدراسة الفجوة الرقمية بالمؤسسات التعليمية دراسة (هيام يوسف، ؛ l ب ب) وقد قامت بدراسة اللامساواة الرقمية في مدارس التعليم الأساسي في مصر وعلاقتها بالتعلم مدى الحياة وقدمت توصيات لسد الفجوة الرقمية بتلك المدارس، ودراسـة (منـي الغانم ، ع ا ب ب)، ودرست طرق ومعوقـات الاتصـال بالمعلومـات الرقميـة ومهـارات الاسـتخدام لــى طـلاب وطالبـات مرحلـة البكالوريوس بجامعة الإمام محمد بن سعود الإسـلامية ، ودراسـة (حنان بيزان، 1 ـ ب التي التي اجريت بليبيا عن تنمية الرأسمال الفكري لتجسير الفجوة الرقمية من وجهة نظر تحليلية ،

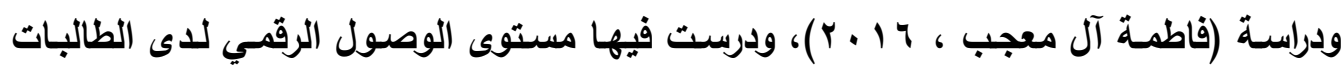
وأغراض الاستخدام ومهارات استخدام تكنولوجيـا المعلومـات والاتصـالات لـى طالبـات كلية التربية بجامعة "ثقراء" وانعكاساتها التريوية، لايهن. (Berrio - مين الدراسـات التي درست الفجوة الرقمية بالتعليم الجامعي دراسـة Zapata , C. \& Rojas, 2014) بكولومبيا وأسباب تلكك الفجوة الرقمية ومعوقات قياسها في التعليم الجامعي. أما دراسة (Pena - Lopez, I. , 2010) فقد قامت بدراسـة جوانب الفجوة الرقمية بالتعليم وآلية سدها ، وأوضحت ضرورة العمل على سدها من خـلال توفير البنية التحتية 
بالمؤسسـة التعليميـة وإكسـاب الطـلاب والمعلمين المهارات الرقميـة اللازمـة وتـوفير المحتوى التعليمي التلازم لذلك.

ودراسة (Tien , F. F. , \& Fu, T.- T. , 2008) التي أُجريث على طلاب التعليم

الجـامعي في" تايوان" وهدفت إلى معرفة أثر الفجوة الرقميـة على الأداء الأكـاديمي للطلاب الجامعين ، وتوصلت إلى أن لها تأثيراً سلبياً على الأداء الأكاديمي للطلاب وأنها نوع من هن أشكال اللامساواة الاجتماعية بين الطلاب.

وتوصلت دراسـة (Naidoo, S. \& Raju, J., 2012) إلى أن من أسباب الفجوة الرقية لاى طلاب الجامعات في جنوب أفريقيا ترجع لأنها تضم مجموعات غير متجانسـة من الطلاب حسب العزّق والخلفيـة الاقتصـادية والخلفيـة الرقميـة، وترجـع إلى عدم توافر البنية التحتية والموارد الكافية لهؤلاء الطلاب في المدارس الثانوية مما أضعف من خبرتهم في مجال تكنولوجيا المعلومـات والاتصـالات وتسبب في فجوة رقميـة لليهز بالجامعة ، وجاءت دراسـة فقامت بدراسـة أسباب الفجوة الرقمية (Khalid , Md. S \& Pedersen, M. J., 2016) بالتعليم الجامعي وتوصلت إلى أن أسبابها فردية ومؤسسية ووطنية وأوضحت فوائد استخدام تكنولوجيا المعلومات بالتعليم الجامعي اللا محدودة. ويلاحظ أن تلك الدراسات أجريت بدول أجنبية او دول عربية شقيقة مـا عدا دراسـة اللامساواة الرقمية بمدارس التعليم الأساسي فقد أجريت في مصر ، لكن لـ يتم دراسـة الفجوة الرقمية وإنعكاساتها التريوية على الأفراد الارسين بالمراحل التعليمية المختلفة في مصر. ومن ثم تأتي الاراسة الحالية لبحث مدى وجود فجوة رقمية لاى الباحثين التربويين لأن وجود فجوة رقمية لاى الباحثين التريويين تعد مشكلة كبيرة لها آثار سلبية على البحث التريوي ويالتالي على المعرفة التريوية لكن في حالة العمل على سدها والقضاء عليها سيؤدي ذلك إلى تطوير المعرفة التريوية بثكل كبير في المجتمع ممـا يؤدي إلى تطوره وتتميته، لأن المعرفة التريويـة سواء الظاهرة أو الكامنـة لها آثار على تطور جميع مخرجات المؤسسـات المختلفة مما يؤدي في النهاية إلى تطور وتنمية المجتمع بأكمله. 


\section{تصور مقترح لسد الفجوة الرقمية لدى الباحثين التربويين كمدخل لتطوير المعرفة التربوية.}

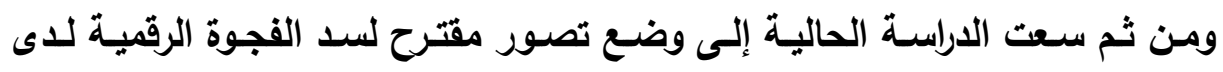

الباحثين التريويين من أجل تطوير المعرفة التريوية ويالتالي تتحدد مشكلة الدراسـة الحالية في

الإجابة عن التساؤلات التالية:

ا - ما انعكاسات العصر الرقمي على المعرفة التريوية، ما دواعي تطوير المعرفة التربوية في

$$
\text { العصر الرقمي؟ - (المي }
$$

r - ما العوامل المؤثرة على حال الباحثين التربويين ودورهم في تطوير المعرفة التريوية؟ ب- ما كفايات الباحثين التريويين اللازمة لتطوير المعرفة التريوية في العصر الرقمي؟

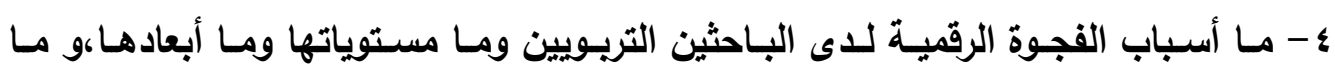

$$
\text { جواتبها وما تداعياتها على المعرفة التريوية؟ }
$$

ه - ما واقع الفجوة الرقمية لدى الباحثين التريويين بمرحلة الماجستير ومرحلة الدكتوراة في

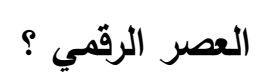

צ- ما التصور المقترح لسد الفجوة الرقمية لدى الباحثين التربويين كمدخل لتطوير المعرفة

$$
\text { التريوية في مصر؟ }
$$

\section{أهمية اثلدراسةحأ}

للاراسة الحالية أهمية ترجع إلى أنها تتناول موضوع الفجوة الرقمية التي توجد للى البـاحثين التربويين والتـي لابـ مـن العمل على سـها لتطوير المعرفـة التربويـة نظرًا لوجهود انعكاسـات للعصر الرقــي على المعرفـة التريويـة ولابــ للبـاحثين التربـويين مـن مواكبـة هذا العصر الرقمي بكل معطياته وضرورة امتلاكهم للكفايات التي تلزمهم للتعامل معه بشكل يؤدي إلى تطوير المعرفة التريوية وتنحصر أهمية الدراسة فيما يلي: ا - تفيد الدراسة الحالية في التعريف بالفجوة الرقمية وأهم انعكاسـاتها على المعرفة التريويـة وأهم دواعي تظوير المعرفة التريوية في العصر الرقمي خاصة في مصر. r - تفيد في تعريف الباحثين بأهم الكفايات التي يجب أن يمتلكوها من أجل مواكبة العصر الرقمي ومن أجل تطوير البحث التريوي والمعرفة التريوية. 
ب- تسـهم في تعريـف المسئولين بكليـات التربيـة بخطورة وجـود خلل في إعداد البـاحثين التربويين ووجود فجوة رقمية لديهم بما يؤثز سلبيًا على الإنتاج العلمي التربوي. ع - تعريف الباحثين وكذلك المسئولين بأسباب الفجوة الرقمية لدى الباحثين التربويين حتى

يستطيعوا تلافيها والقضاء عليها. ه- تسـهم في تعريف المسئولين بكليـات التربيـة ومراكز البحوث التريويـة والجامعات بمدى أهميـة سـد الفجوة الرقمية لـد البـاحثين التريويين وتعريفهز بآليات سـدها تدعيماً للمعرفة التريوية. צ- تسهم الاراسـة في وضـع تصور مقترح لسد الفجوة الرقية لاى الباحثين التربويين من أجل تطوير المعرفة التريوية ، وهذا التصور قابل للتطبيق على أرض الواقع العملي. V- يمكن أن تسهم الدراسة الحالية في العمل على تطوير وتحسين البحث التربوي ومن ثم

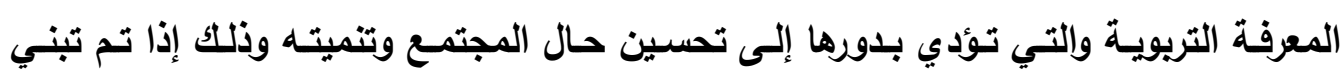
الجهات المسئولة للتصور المقترح وتنفيذه على أرض الواقع بكليات التربية ومراكز البحوث التريويـة في مصر وخاصـة في حالـة توفيرهم للمتطلبـات اللازمـة لسـ الفجوة الرقميـة لـى الباحثين التريويين في المستقبل.

\section{حدود الداساسة}

اقتصرت حدود الاراسـة على دراسـة انعكاسـات العصر الرقمي على المعرفة التريويـة ودواعي تطويرها وأهم الكفايات المطلويسة في الباحثين التربويين في العصر الرقمي، وأسباب الفجوة الرقمية لايهم ومدى وجودها لديهم وأهم معوقات القضاء عليها، وتم التطبيق الميداني لأداة الداسة التي هدفت للتعرف على واقع الفجوة الرقمية لدى الباحثين التريويين وذلك على عينة من الباحثين بمرحلة الماجستير ومرحلة الدكتوراه بكلية التربية بجامعة سوهاج ويعض

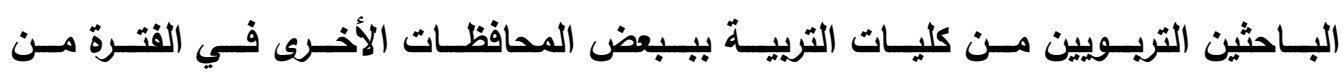

$$
\text { 19/r/11 }
$$

مثرج الداساسة 
تصور مقترح لسد الفجوة الرقمية لدى الباحثين التربويين كمدخل لتطوير المعرفة التربوية.

اعتمدت الباحثة في هذه الدراسـة على المنهج الوصفي وذلك لملاعمته لموضـوع

الاراسة الحالية وتم استخدامه وفقًا للخطوات التالية:

جمع الدراسـات السـابقة والأدبيات المتصلة بموضـوع الدراسـة وقراعتها وتحليلها وتحديـ

مشكلة الاراسة.

إعداد الإطار النظري للاراسة بحيث يغطي جميع النقاط المراد دراستها والتأصيل النظري

إعداد أدوات الدراسة الميدانية ثم تقنينها وتعديلها حتى أصبحت قابلة للتطبيق الميداني. • طبيق أدوات الدراسة الميدانية ثم تفريغ الاستبانات واستخراج النتائج ووصفها وتحليلها. وضـع التصـور المقترح لســ الفجـوة الرقميـة لـى البـاحثين التريـويين في ضـوء نتائج

الاراسة النظرية والدراسة الميدانية.

أدوات الدراسةحُ

استخدمت الباحثة الأدوات التالية:

- استبانة مـن إعداد الباحثة للتعرف على واقع الفجوة الرقميـة لـى الباحثين التربويين وكذلك للتعرف على أهم أسباب الفجوة الرقمية لايهم.

r- المقابلـة الثخصية غيـر المقتــة مـع البـاحثين والباحثـات بمرحلـة الماجستير ومرحلـة الاكتوراة للتعرف منهم على تفاصيل واقع الفجوة الرقمية لديهم وأسبابها وجوانبها ومعوقات القضاء عليها وأهم مقترحاتهم للقضاء عليها لايهم وذلك أثناء إعداد وتطبيق الاستبانة.

مينة الدراسة

تم تطبيق أداة الاراسـة وهي الاستبانة على عينة من الباحثين والباحثات بمرحلة الماجستير و مرحلـة الـدكتوراه بالأقسـام التريويـة المختلفـة بكليـة التربيـة بجامعـة سـوهاج ويعض الباحثين ببعض كليات التربية الأخرى ويلغ عدد الاستبانات الصحيحة وإلمكتملة التي

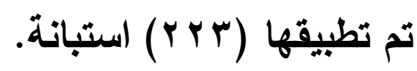


مصطاتحات الدراسلة:

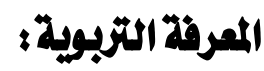

تعرف الدراسة الحالية المعرفة التريوية إجرائيًا "بأنها هي نتاج مجموع جهود العلماء والمفكرين والباحثين التربويين ومـا توصلوا إليه من إنتاجية علمية ومعرفية تفيد في تطوير عملية تربية وتعليم ويناء الإنسان وتحسين الممارسات التعليمية والتربوية في المجتمع".

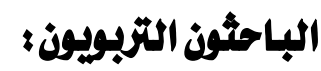

تعرف الدراسة الحالية الباحثين التربويين بأنهم هم عمال المعرفة التربوية الساعين

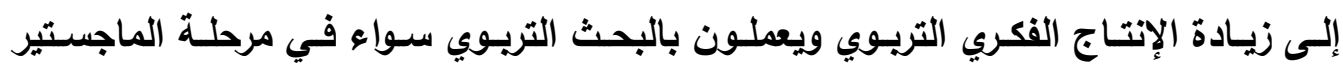

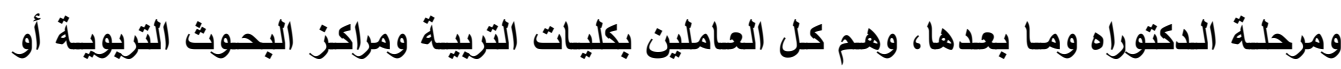
المنضمين لفئة البحث التريوي من الخارج".

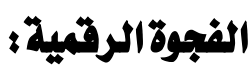

تعرف الاراسة الحالية الفجوة الرقمية إجرائيًا بأنها "هي عدم المساواة الرقمية بين

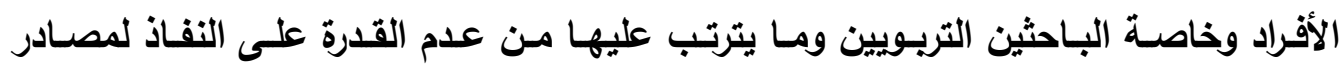

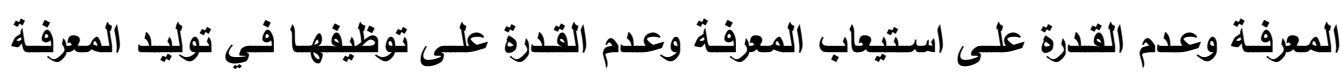

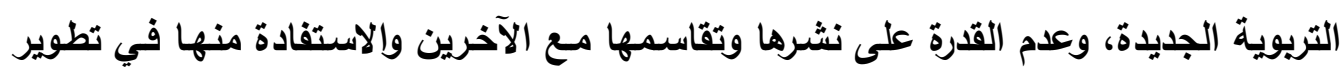

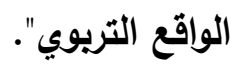

وسوف يتم توضيح تلك المصطحات بثكل تفصيلي في الإطار النظري للاراسة.

\section{خطال السير في الدراسلة:}

بعد اطلاع الباحثة على الدراسـات السـابقة والأدبيات التربويـة ذات الصلة بموضوع

الاراسة الحالية ، تم تحديد مشكلة الاراسة وتم السبير في الاراسة وفقًا للذطوات التالية: 1 - الإطار العام للدراسلة: وجاء بهذا الجزء تحديد لمشكلة الدراسة وأهميتها وحدود الدراسة ومنهج الاراسة ومصطعاتها وخطة السير في الداسة. 
r - الإطارالنظري للدراسة: وجاء الإطار النظري مكونًا من ثلاثة أجزاء وهي:

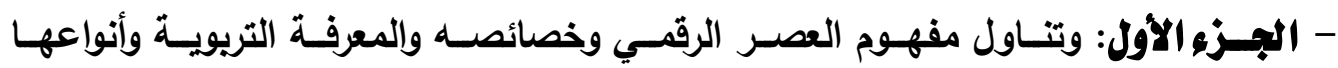
وانعكاسات العصر الرقمي على المعرفة التريويـة ، ودواعي تطويرهـا في العصر الرقمي وجاء هذا الجزء ليجيب عن التساؤل الأول من تساؤلات الاراسة. - الجـزيه الثهاني: وهـو عن العوامـل الموئثرة على حال الباحثين التريويين ومنها اختيـارهم وإعدادهم وترقيـاتهم، وأهـم الكفايـات اللازمـة للبـاحثين في العصـر الرقمسي لتطوير المعرفة التريوية وجاء هذا الجزء ليجيب عن التساؤل الثاني والتساؤل الثالث من تساؤلات الدراسة. - الجزء الثاله: وجاء به توضيح لمفهوم الفجوة الرقمية لدى الباحثين التربويين ومستوياتها وأبعادها وأسبابها وجوانبها وأهم تداعياتها على المعرفة التريويـة وجاء هذا الجزء ليجيب عن التساؤل الرابع من تساؤلات الدراسة.

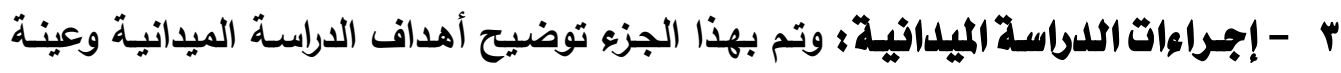
الدراسـة وأسـلوب اختيارهـا وأدوات الدراسـة وتقتينهـا وتطبيقهـا وأسـلوب المعالجـة الإحصـائية لتتائج الدراسة الميدانية. ع - نتائج الدراسلة الميلدانية؛ وجاء بها نتائج الدراسـة الميدانية حول واقع جوانب الفجوة الرقمية للى الباحثين التربويين وجاء هذا الجزء ليجيب عن التسـاؤل الخامس من تساؤلات الدراسة.

0 - التصورالمقتزح: وتم بـه وضع مجموعة من الآليات لسد الفجوة الرقمية لدى الباحثين التريويين من أجل تطوير المعرفة التريويـة وجاء هذا الجزء من الدراسـة ليجيب عن التسـاؤل السادس والأخير من تساؤلات الدراسة الحالية. 
الإطارالنثريج

\section{أولا : المعرفة التزبوية وضرورة تطويرها في المصر الرقيمي:}

\section{(أ) مفهوم العصر الرقهي، وأهم خصائصه :}

أصبح المجتمع يعيش حاليًا في ما يسمى بالعصر الرقمي ”Digital Age" وهو

العصر الذي سبطرته عليه تكنولوجيا المعلومات والاتصالات بثكل كبير على جميع مناشط ونسواحي الحيـاة المختلفـة الاقتصـادية والاجتماعيـة والثثقافيـة، و"تمثل تكنولوجيـا المعلومـات والاتصالات - لو أحسن استغلالها - فرصة ثمينة للإسراع بجهود التنمية المجتمعية الثاملة

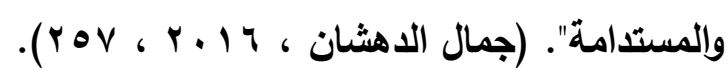

ويعرف العصر الرقـي بأنه هو ببساطة "العصر الذي توجد بـه القدرة على تحويل

المعلومات والمعارف والبيانات والأثكال والصور وكل ما يتطلق بذلك من الصورة التقليدية إلى لـى لتصني الرقمية التي يتم نقلها خلال شبكة الإنترنت إلى تقتيـة إلكترونيـة مثل الهاتف والكمبيوتر

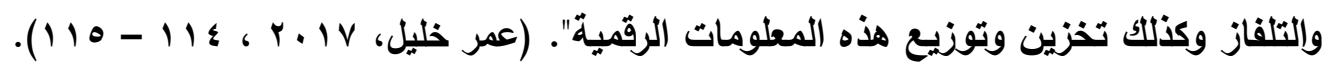
ويعرف العصر الرقمي بأنه "يعني أن كل أثنكال المعلومـات يمكن أن تصبح رقمية: النصوص والرسومات والصور الساكنة والمتحركة والصوت، وتتلك المعلومات يتم انتقالها خلال شبكة المطلومات الدولية بواسطة أجهزة إلكترونية وسيطة (الحاسب الآلي - الهاتف)". (ندى

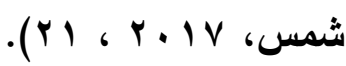

ومن ذلك يمكن القول أن العصر الرقمي هو العصر الذي سيطرت عليه تكنولوجيا

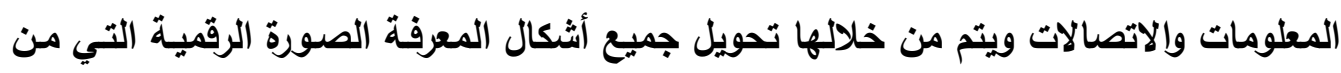
السهل تنقلها وتبادلها عن طريق شبكة الإنترنت باستخدام الحاسب الآلي والهواتف الذكية

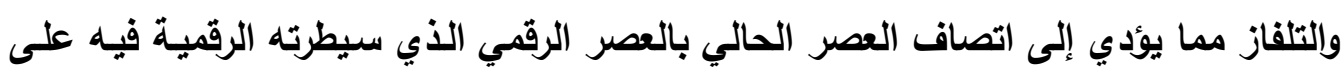
جميع مناشط الحياة.

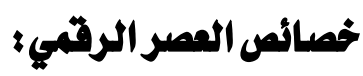


يتميز العصر الرقمي برقمنة المعلومـات بجميع صورها وسرعة تبادلها وتتاقلها ممـا يسـاعد على انتثـارها في وقت وجيز وسـاعد ذلك على تضـاعف إنتاج المعرفة في الآونـة الأخيرة أضعاف مضاعفة بالمقارنـة بالعصور السـابقة، ومن أهم خصائص العصر الرقمي مـا

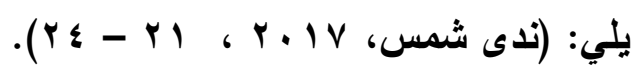

1- انفجار المعلومات وتعدد مصادرها وزيادة أهميتها.

r - نمو المجتمعات والمنظمات المعتمدة على المعلومات.

ب - تعدد فئات المستفيدين من معلومات العصر الرقمي مثل العلماء والمفكرين والاقتصاديين

وإلقنانين والأطباء والمهندسين.

ع - تتـامي الفكر الإكترونسي الذي سـاعد على سـرعة الحصول على المعلومـات، والمحافظة عليها من التلف وسهولته بسبب رخص تكلقته. ه - سرعة التحديث في العصر الرقمي بسبب الاندماج في العالم الرقمي. צ- الأبعاد الجديدة للخصوصية المتعلقة باختزان واسترجاع المعلومات وإمكانية الوصول

وتميز العصر الرقمي بتلك الخصائص التي تفرض تحديًا كبيرًا على كل من يعمل في المجال البحثي حيث يجب عليه متابعة مـا يحدث في العصر الرقمي من انفجار معلومساتي كبير حتى يستطيع أن يستفيل من كل مصادر المعرفة الرقمية لمواكبة كل مـا هو حديث منها ويستطيع توظيفها كل في مجال بحثه مما يؤدي إلى إنتاج معرفة جديدة ومفيدة للمجتمع.

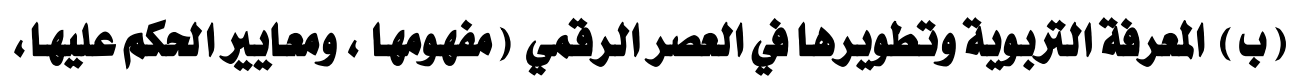

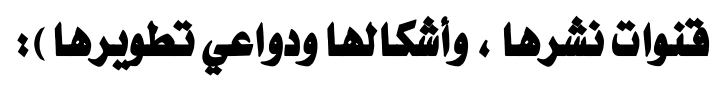

* م⿳⺈⿴囗十)

تعد المعرفة التريوية من أهم أنواع المعرفة نظرًا لأنها تهتم بالبناء الإنساني وجميع مكوناته والذي يعد هو حجر الأسـاس والمنتج لكل أنـواع المعرفة الأخرى، وتعرف المعرفة 


\section{تصور مقترح لسد الفجوة الرقمية لدى الباحثين التربويين كمدخل لتطوير المعرفة التربوية.}

التريوية "بأنها منظومة من المفاهيم أوالاعتقادات الحقيقية التي تحقق للفرد في مراحل عمره

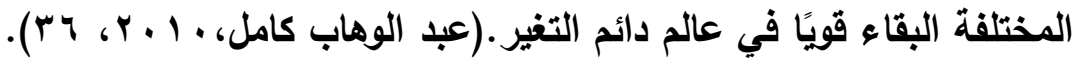
وتعرف المعرفة التربوية على "أنها هي نتاج الممارسات التي بذلها نفر من العلماء

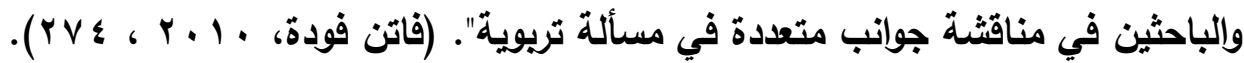
وتعرف بأنها هي محصلة العلم بالحقائق والأفكار والعلوم التي تعني بتربية ورعاية الإنسـان وتعليمـه وتبليغه كماله شيئًا فشيئًا باستخدام مجموعة السبل الموصلة لذلك، وهي تلكك الجهود العقليـة التي بـذلها ويبذلها نفر مـن العلمـاء والمفكرين والباحثين في مناقشـة جوانب متعددة في المسائل التريوية. (صلاح توفيق، سماح محمد ، ب ا ـ ب ، 0 1 ). والمعرفة التربويـة منها مـا هو كامن داخل الأفراد ومنها مـا هو ظاهر في الكتابـات والمؤلفات التربوية ، وتتلك المؤلفات والكتابات منها مـا هو موجهه لعامـة المربين في المجتمع

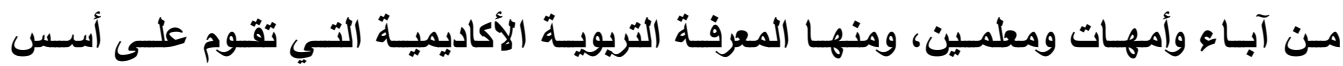
علميةوتسمي المعرفة التريوية الأكاديمية وهي المقصودة بهذه الدراسة. ويالتالي يمكن القول أن المعرفة التريوية هي النتيجة النهائية لمجموع جهود العلماء والمفكرين والباحثين التربويين في المجال التربوي ومـا توصلوا إليهه من نتاج فكري ومعرفي يفيد في الارتقاء بعملية تربية الإنسان وتعليمه وفي تحسين الممارسات التريويـة وإلتعليمية في المجتمع، ويتمثل في الكتابات التربويـة من كتب ورسـائل علمية وأبحاث تربوية ومجلات تريوية وكذلك المؤتمرات التريوية المتخصصة، وهذا التراث الفكري التريوي يمثل حجر الأسساس للبناء الفكري الذي يزداد مع مر العصور ويتطور مع تطور العلم وتطور المجتمع.

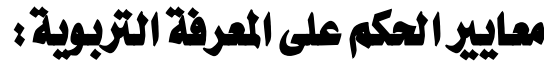

إن المعرفة التريويـة الجيدة والمفيدة للثـعوب والأمم تتصف بمجموعة من المميزات

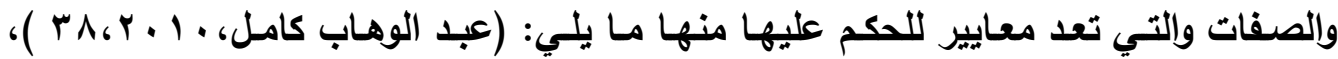

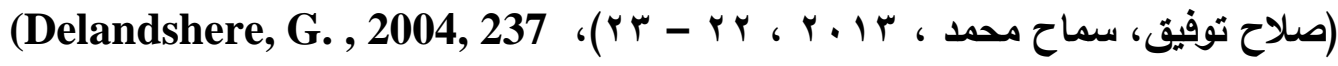


ا- إن المعرفة التريويـة بنائية ارتقائية في جميع جوانب حياة الإنسـان، وتظهر آثارها على تهئ المجتمع ككل وليست حالات فردية. r - المعرفة التريويـة لابد أن تؤدي إلى التماسك الداخلي للفرد وتقوي علاقته بنفسـه ويمن حوله في المجتمع. ب- المعرفة التريويـة تحمي الفرد من الفيروسـات الفكريـة والفيروس الفكري هو عبـارة عن اعتقادات ومفاهيم سلبية وخاطئة ويتبناها الفرد وتؤدي لإفساد العمل ، وتعطيله وتقطع علاقة الفرد بالآخرين.

ع - المعرفة التريوية هي منظومة من الأوعية الثقافية التعليمية. ه - المعرفة التريوية هي منظومة انفعالية وعقلية وسيكولوجية (المهارات) لابد أن تؤدي إلى تغيير الواقع تغييرًا ارتقائيًا. צ- المعرفة التريوية تتصف بالمرونة وتقبل الرأي الآخر. V- المعرفـة التريويـة تكسب الفـرد مهـارات وأحاسيس التـوق الجمـالي والتـذق الأخلاقي والتذوق القني. 1- المعرفة التريوية منظومة متناغمة تعرف فيها جميع المقررات الدراسية والخبرات العملية والأنشطة التربوية بحيث تؤدي إلى بناء عقل قادر على الاستيعاب المعرفي المعلوماتي. 9- المعرفة التربويـة هـ التي تهـف لتحسين الممارسـات التعليميـة وتكون بها مسئولية أخلاقية واجتماعية وسياسية تجاه المجتمع ولا تتحاز لمصالح معينة بل تكون محايدة هدفها الصالح العام.

ويضاف إلى ما سبق أن المعرفة التريوية الحقيقية هي المعرفة التربوية التي يستخدم الأسـلوب العلمـي في إنتاجها وتتســ بالأصـالة والحداثة وتضسف للرصيد المعرفي التربـوي وتسـهم في حل مشـكلات تريويـة بـالمجتمع، وهـي التـي تـؤدي إلسى تطوير الواقـع التربـوي بـالمجتمع وتحسن الممارسـات التربويـة لاى الأفراد في جميع بقاع المجتمع وتؤدي لتطوير

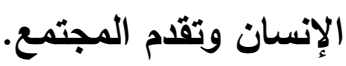




\section{قتوات نشر المعرفة التزبوية ( أشكالها )؛}

إن قـــات نثــر المعرفـة التريويـة تتمثل في الكتب التريويـة، ورسـائل الماجستير والاكتوراة، والبحوث والدراسات التريوية التي تنشر إما في دوريات تريوية متخصصة أو في مؤتمرات تريوية محلية أو إقليمية أو دولية ويتم نثر المعرفة في شكلين هما:

\section{(1) (المعرفة التربوية الورقية:}

ويتمثل الثكل الورقي في توفير المنتج المعرفي في شكل مطبوعات من كتب أو

رسائل أو مجلات تريوية أو نثرات ويتوفر للقراء والباحثين والتربويين. "وتتمثل أهمية المعرفة التربويـة الورقيـة في سـهولة الرجوع إليهـا مـن جميـع الأفراد المثقفين تكنولوجياً أو غير

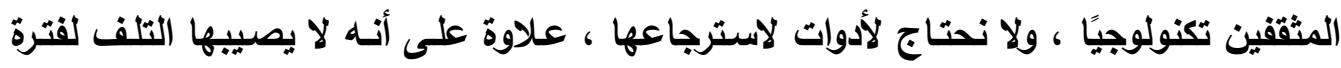

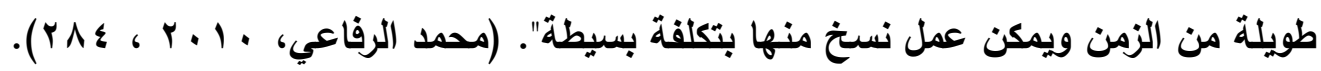

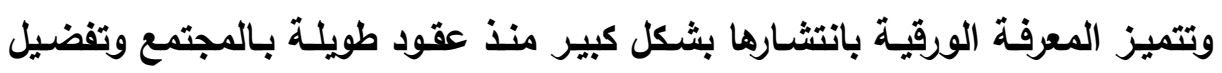

عدد كبير من المواطنين والباحثين في الرجوع إليها.

\section{(r) المعرفة التربوية الإكترونية:}

حيث أدى التقدم العلمي والتكنولوجي إلى ظهور المعرفـة التريويـة التي يتم نشرها بثكل إلكترونسي عبر الإنترنتـ والمكتبـات الرقميـة وقواعد البيانـات العالميـة وينوك المعرفـة المختلفة "وتتلضص أهمية المعرفة التريويـة الإكترونية في سهولة وصول الأفراد والباحثين إليها في أي وقت وفي أي مكان ، كما يسـهل تحديثها لخطأ بواسطة المؤلفين أو التعليق

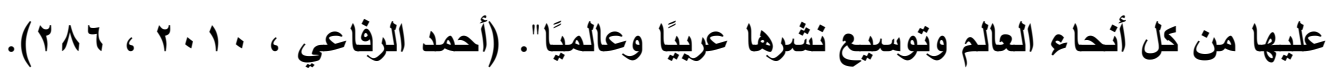
والمعرفة التريوية الإكترونية يهيمن فيها - ليس من ينتج المعرفة فقط - بل من ينتجها ويستطيع نشرها إلكترونيًا عبر الإنترنت بشكل جيد يسهل عملية تداونها وانتشـارها عربيًا وعالميًا مما يحقق أكبر استفادة من تلك المعرفة التريوية. 


\section{(ج) أزمة المعرفة التربوية في العصر الرقيمي}

لقد أجمع عدد كبير من كبار العلماء والمفكرين التربويين على وجود أزمـة بالمعرفة التربوية ، ومن أهم تلك الأراء التي عرضت أبرز مظاهر أزمة المعرفة التريوية هو رأي سعيد

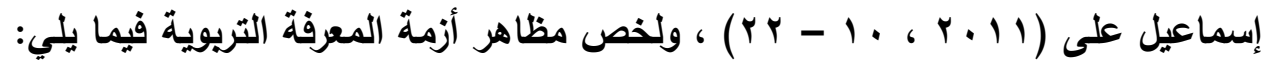
1 - تيه المويلة حيث إن الأزمة التي تصيب أي مجتمع في مجال ما قد لا تكون ناتجة عن افتقاد الهوية فقط، بل الناتجة عن تعدد الهوية، ويالتالي لابد من هوية واضحة للمجتمع تظهر في المنتج الفكري له. Y - الاستخراق في الفنياتٌ مثل الاستغرلق في طرق التعليم ، والمنهج وشروطه وتقسيم المراحل الدراسية وكيفية الإدارة وتنظيم اليوم الدراسي حيث يتم الاهتمام بالتفاصيل وتغيب الروئية الكلية للإصلاح. r - مياب النقد التزبوي؛ ويعني بذلك قلة النقاد التريويين الذين يجب أن يقوموا بالنقد من أجل تطوير المعرفة التريوية في مصر. ع - التقوقع التزبوي:والمقصود بذلك تقوقع الدراسات والبحوث التريوية على دراسة النظام وسياساته ومناهجه ومشكلاته ومقارنته بغيره وإهمال دراسة جواتب المجتمع وطبقاته ،وتأثير الفنون الشعبية والإعلام والسينما على المعرفة التريوية بالمجتمع.

0 الآخر مما نتج عن ذلك تشرزم معرفي وتثظي تريوي وغابت وحدة المعرفة التربوية. 1 - الجسورالتي تهلمث: حيث تهدمت جسور الوحدة العربية في مجال الفكر التربوي فلا توجد أي جهود حاليًا مبذولة لتوحيد الصف التربوي بين الدول العربية. V - تشئوهات التكوين حيث تثوهت إعداد الباحثين التريويين والذين يقومون بممارسة البحث التريوي بنظام التكليف بدون معايشة للواقع التربوي والذي يجب أن يحدث بشكل أكبر مما هو متبع حاليًا. 
A - الانقطاع المرافي عن الجدور التاريخية: حيث يوجد في تاريخنا العظيم جهود تريوية كبيرة لعلماء عدة ، والباحثين التريويين لايهم جهل بجملة جهود هؤلاء العلماء في المعرفة التريوية والتي يجب الرجوع إليه.

وهناك رأي آخر بضيف بعض المظاهر الأخرى في المعرفة التريوية هي: (عبد

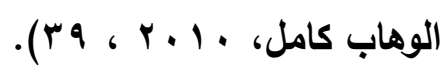

1 - الاهتمام بالتحصيل المعرفي المتمثل في الكتب وإهمال معرفة المهارات والأداء العملي. r - عدم الاستفادة من وفرة المعومات التي وفرتها تكنولوجيا المعلومات وضعف استخلامها

وتوظيفها. ب- الأزمـة في المعرفة التريويـة في موقف الإنسـان العربي المتمثلـة في النقل أو القبول والتسليم بدون وعي، أوالمقاطعة بالرفض والمخاصمة بدون تفكير. وتضيف الاراسة الحالية أن من أهم مظاهر أزمة المعرفة التريوية في العصر الرقمي هو ضعف قدرتها على مواكبة التقدم التكنولوجي والمعرفي المتزليد في المجتمع المحيط بها

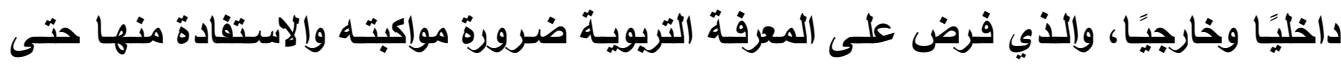
نستطيع المعرفة التريوية المحلية اللحاق بركب التقلم المعرفي التربوي العالمي، ومن مظاهر أزمـة المعرفة التربويـة أيضًا هو فثـلها الكبير وعدم قدرتها على حل المشكلات التريويـة بالمجتمع المصري ، وسوء أحوال التطليم وضعف مستوى مخرجاته وتلني المستوى الأخلاقي لاى كثير من الثباب، وضعف الانتماء والولاء وإنتشار التدخين وتعاطي المخدرات وتفشي الأمراض وسوء الأحوال الصحية كل ذلك ناجم عن ضعف وأزمـة بالمعرفة التريوية بالمجتمع، وفي العصر الرقمي وما فرضه من تحديات جديدة على المعرفة التريوية ظهرت مظاهر أخرى لأزمسة المعرفة التريوية منها ضعف تواجدها في الفضاء الرقفي الذي هيمن عليه المحتوى المعرفي بلغات أخرى وضسف المحتوى التربوي باللغة العربية ، بالإضـافة إلى عدم وجود

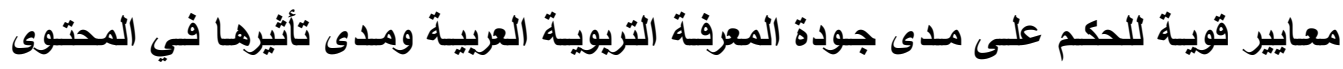
المعرفي التريوي في العالم المحيط عريبًا وعالميًا. 


\section{( ) ) انعكاسات المصر الرقيمي على التربية والمعرفة التزبوية:}

- هنـاك عدة انعكاسـات متعددة للعصر الرقمـي على التربيـة والمعرفة التريويـة ومـن أهم انعكاسات العصر الرقمي على التربية ظهور كلاً من المدرسـة الذكية والمدرسـة الافتراضية ، ومنظومة البيئة المدرسية والتغير المرتبط بالثورة الرقمية، والمباني المدرسية الأكية والفراغات الافتراضية، والأنشـة المدرسية الرقميـة مثل نظـام المحاضـرات الرقميـة ونظسام الاختبـارات الرقمية والمكتبة الرقمية ونظام الحضور والإنصراف الرقمي والوسـائل التعليمية الرقمية. (تدى

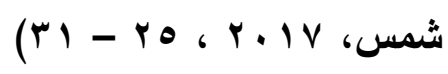

- ومـن أهم انعكاسـات العصر الرقمـي على المعرفـة التريويـة هو ظهور مصـادر للمعلومـات الرقمية منها المكتبات الرقمية التي تحتوى على محتوى لا نهائي من المعلومـات وأيضًا من مصادر المعلومـات الرقمية قواعد البيانـات العالمية التي تحتوى على كم كبير من الدوريات العلمية وإلتربوية الثرية في محتواهـا العلمي والمعرفي الموثوق فيه وفي دقته العلمية وذلك يرجع للنشر الالكتروني للمعرفة التريوية. - ظهور تلك المصادر الرقمية للمعلومات التريوية فرض تحديًا كبيرًا على الباحثين التربويين وهو ضرورة متابعة كل تلكك المصادر الرقمية والتدريب على كيفية استخدامها واكتساب كل مـا يلزم ذلك من معلومات ومهارات وذلك يحتم على الباحثين التربويين استمرارية التعليم لمواكبة التطور التكنولوجي. - وأهم انعكاسـات للعصر الرقمي على تعليم الباحثين التريـيين وهو التحول الرقمي بكليات التربية والجامعات المصرية وذلك يعني إحلال النظم الآلية محل العمل البشري التقليدي خاصة في مجالات الخدمات التعليمية والتدريبية، بمـا ينعكس على هياكل المنظمات وتكوين الموارد البشرية بها، حيث تزيد أهمية الأصول الفكرية غير الملموسة عن الأصول المادية الملموسـة في تكـوين اسـتثمارات المنظمـات المعاصـرة". (على السـلمي، ه . . ب ، ه)، وذلـك التحـول الرقمـي يعنــي أيضًا اسـتبدال العناصـر الماديـة بالعناصـر الرقميـة وإلتثـجيع علـى تفعيـل 
وللعصر الرقمي آثار متعددة على الباحثين التربويين وإعدادهم. ومنها على سبيل المثال التعلم عن بعد بالدبلومات العامة والتواصل الإلكتروني ونظام الاختبارات الإكترونية وإلتصحيح الإكترونـي والحاجـة الماسـة لاستخدام المكتبـات الرقميـة ومصـادر المعرفة الرقميـة المختلفة وضرورة اكتساب ما يلزمها من مهارات وتطويرها. - وأهم انعكاس للعصر الرقمي على الباحثين هو ضرورة تعلمهم المستمر لكل مـا هو جديد في العصر الرقمـي لمواكبتهـه خاصـة تعلم وإتقان اللغـة الإنجليزيـة نظرًا لكبر حجم المحتوى المعرفي المتاح باللغة الإنجليزية وقلة المحتوى المعرفي المتاح باللغة العربية على الإنترنت. - يفرض العصر الرقمي على الباحثين التريويين ضرورة وجود إنتاج تربوي لهم على خريطة

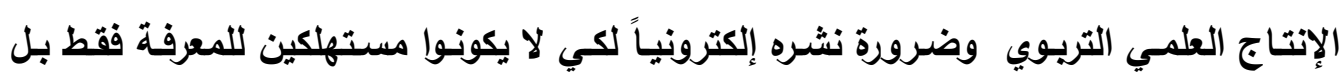
يجب أن يكونوا منتجين لها أيضًا. كانـت تلكـ أمثلــة لانعكاسـات العصـر الرقمـي على المعرفـة التربويـة التي أصبحت واضحة ومؤثرة على المعرفة التريويـة بشكل كبير جدًا وغالبيـة تلك انعكاسـات لصالح تطوير المعرفة التريوية إذا أحسن استخدام كل معطيات العصر الرقمي وتوظيفها بشكل جيد. اتضح من الصفحات السابقة وجود أزمة للمعرفة التريوية في العصر الرقمي - ومن ثم لابد من تظوير المعرفة التريوية وفيما يلي سيتم توضيح دواعي وجواتب هذا التطوير المنشود.

\section{( ) دوامي تطوير المعرضة التزبوية في العصر الرضمي؛}

إن المعرفة التريويـة تمر بأزمـة اتضحت بعض مظاهرهـا في الصفحات السـابق ممـا

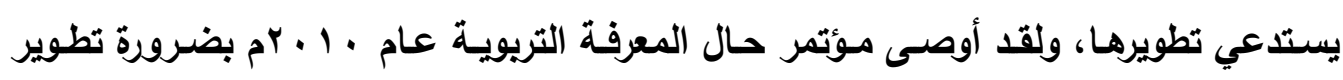
المعرفة التريويـة واتخاذ كل مـا يلزم لذلك، أمسا في الوقت الحالي ويعد ثمان سنوات من هذا المؤتمر فإن المعرفة التريوية ما تزال في أزمة بل تزايدت تلك الأزمـة خاصة في دخول العصر 
فإن المعرفـة التريويـة يجب أن تواكب التقدم التكنولـوجي والعصـر الرقمسي وتتـاح المعرفة التريوية بشكل إلكتروني ويكون محتوى جيد وقيم يكون بالإمكان الاستفادة منه في تحسين الممارسات التربوية والتعليمية بالمجتمع المصري وتوجد عدة دواعي لتطوير المعرفة التريوية ومنها ما يلي: 1 - تدني محتوى بعض المنشورات التريوية الورقية لأن هناك أفراد ليس لهم هدف من نشر

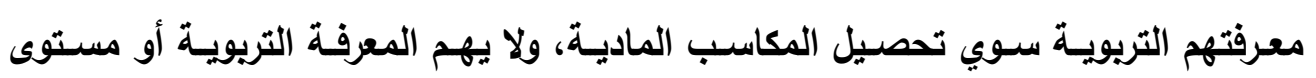
إخراجها مثل بعض الكتب الجامعية والمذكرات المدرسية، كما أن هناك بعض الكتب غير واضحة الكلمات أو طباعتها ضعيفة أو ملونة بهاف عدم تمكين الآخرين من نسخها وفي

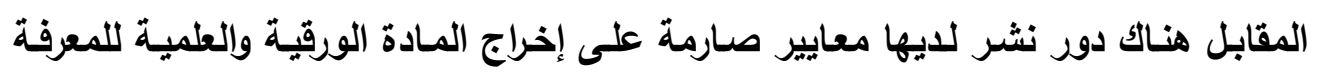

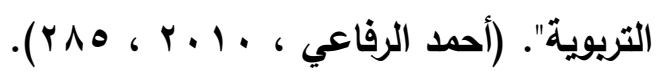

r- تدني كم المنثـورات التزيوية بمصر والعالم العربي بالرغم من نـوه بثكل كبير بالدول

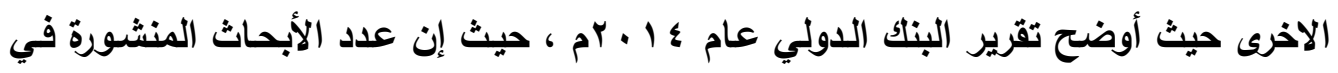

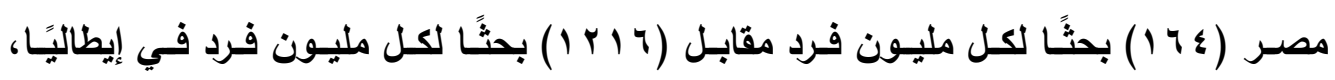

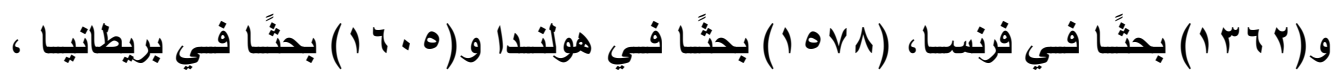

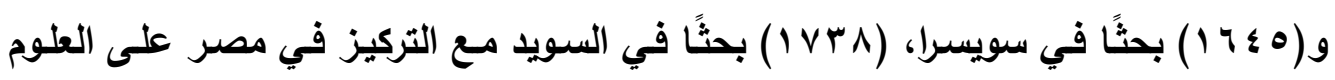

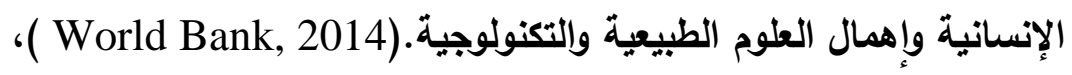

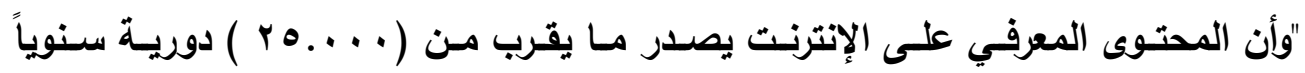
وتتثـر مـا يقرب مـن(r.0 ) مليون بحث ممـا يجعل هنـاك تحدي كبير على البـاحثين

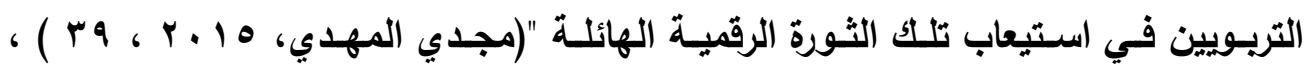

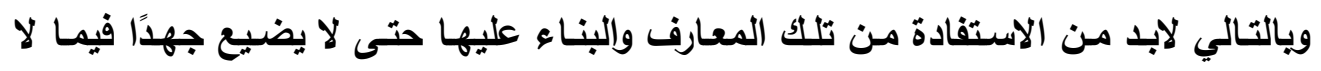

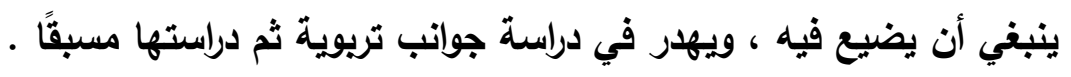

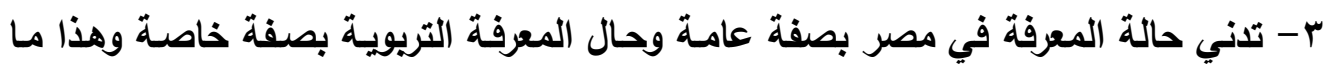
كثف عنه تقرير المعرفة العربي 9 .. بام، وقد أوضح ذلك من خلال عدة مؤثرات كاشفة 


\section{تصور مقترح لسد الفجوة الرقمية لدى الباحثين التربويين كمدخل لتطوير المعرفة التربوية.}

عن الأمية المعرفية والرقمية التي يعيشها المجتمع المصري والعربي، وأوضـح هذا التقرير ضرورة تطوير المعرفة وحدد عدة شروط لتطويرهـا من بينها البيئات التمكينيـة ، والتعلم الراقي وجيد النوعية وينـاء القدرة الذاتية على البحث والتحول نحو مجتمع المعرفة وإنتاج المعرفة والتعليم المستمر · (برنامج الأمم المتحدة الإنمائي ، 9 . . ب م).

ع - نـــرة المعرفـة التربويـة العربيـة مقارنـة بالمعرفـة الغربيـة وأن معظمهـا يسـوده التبعيـة والتقليديـة وعدم الابتكار والإبـاع ، وهي معرفـة تابعة ومقلدة للغرب تـارة أو للسـف تارة أخرى دون نقد أو تحليل أو إبداع ودون إدراك في الغالب لظروف إنتاج تلك المعرفة سواء

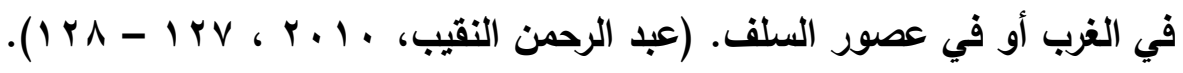

ه- ما زالت المعرفة الورقية هي المسيطرة على المعرفة الإلكترونية في العصر الرقمي، وهذا مـا توصلت إليسه إحدى الاراسـات وأثثتت أن الدرويات العلميـة المصرية التريويـة نـادرًا مـا يوجد لها مواقع على شبكة الإنترنت وغالبية الموجود ليس على المستوى المطلوب (أحمد

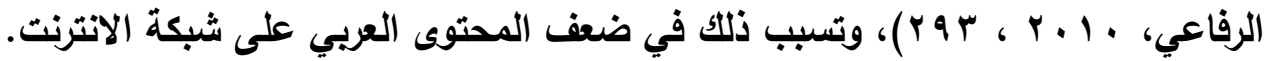
צ- وجود تداعيات لحال المعرفة التريويـة على الممارسـات التربويـة في المجتمع وأن الأمور المتصلة بالواقع والممارسة التريوية تعد شواهد على حال المعرفة التريوية وإرتباطها بحال

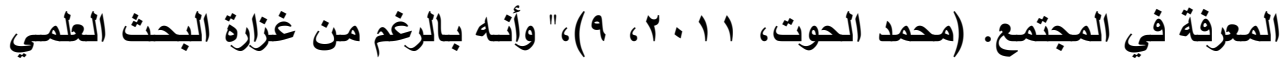
إلا أن هناك ضعف في الممارسة المهنية بسبب ضعف الاهتمام بصقل الباحثين وإعدادهم لإجراء بحوث باستخدام مصـادر المعلومـات المتجددة والعمل على إيجاد الوعي بأهميـة البحث الرقمي الذي يجب أن يكون من ضمن الأولويـات والمهارات المطلويـة للباحثين ") (Smith,K. \&Harvey,R.,2006,612 ) ، وذلك يوضـح تدني مستوى الممارسـات التريويـة بـالمجتمع والمؤسســات التريويـة والتعليميـة يعكس حـال المعرفـة التربويـة التـي بحاجة ماسة للتطوير. وذلك لأن المعرفة التريوية لابد أن تؤثثر على الواقع والممارسات التريوية وتحسنها وأوضحت دراسة (Whitehead, J. , 2010, 1 - 15) أن جميع المنشورات والمخرجات 
تصور مقترح لسد الفجوة الرقمية لدى الباحثين التربويين كمدخل لتطوير المعرفة التربوية.

الأكاديمية المنشـورة في مجـالات مرموقة ليس لها فائدة مـا لـم تؤثثر على الممارسـات التعليمية بالمؤسسـات التعليميـة، وذلك يتطلب عدة جهود لابـ أن تتضـافر لتحقيق ذلك

وتحويل نتائج البحث التريوي إلى واقع عملي يحسن الممارسة التريوية والتعليمية. V- إن المعرفـة التريويـة المنشـورة على الإنترنــت مـن المنشـورات وإلمجـلات وإلـدوريات Impact المصرية ليس لها تصنيف على المستوى العلمي ولـيس لها معامـل تأثير مثل الـدوريات التريويـة الإكترونيـة في بـاقي دول العـالم ممـا يزيـــ الثقـة في المجلات الأجنبية ذات معامل التأثير المعروف ، وهذا مـا ينـادي بـه مشروع معامل التاثير العربي لعمل معامل تأثير للمحلات العلمية التي تصدر باللغة العربية بهدف تطويرها. ^- إعطاء اللجـان العلميـة للترقيـات درجـات مرتفعة للدوريات التريويـة العالميـة الإكترونيـة وخاصة الأجنبية ثم المجلات العربية ثم دوريات مصرية قليلة جدًا غير إلكترونية ، وذلك يتطلب وضـع معايير صـارمة لجودة المجلات واللدوريات التريويـة المصرية ومعايير للنشر

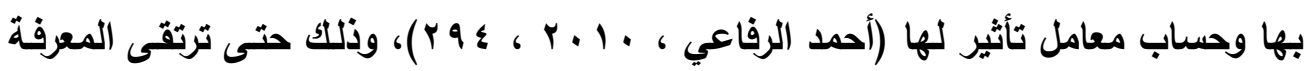
التربوية لمستوى المعرفة التريوية العالمية. 9- الاعتقاد السـائد بأن مسئولية التطوير هي مسئولية الأسـاتذة التربـويين فقط، ويالتالي يجب التأكيــ علـى ضـرورة أن تـتم عمليـة مراجعـة وتطـوير للمعرفـة التربويـة فـي إطـار مؤسسات وليس فقط عن طريق جهود فردية مخلصة من جانب الأساتذة وحدهم بل لابد أن يشـاركهم مسئولية التطوير المؤسسـات التريويـة على أن يوجد في الاعتبار الواقع العلمي لـي

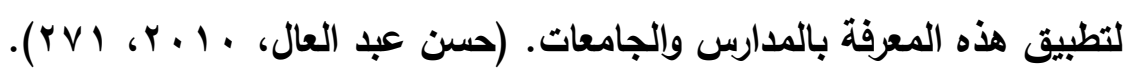

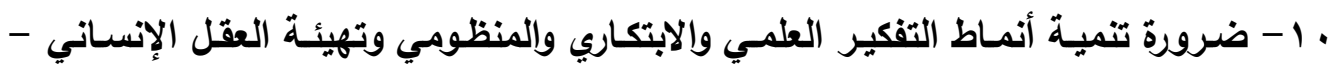
بالمعرفـة التربويـة - للتعامـل مـع تعـديات الواقـع الثقـافي المعاصـر (حسن عبــ العـال،

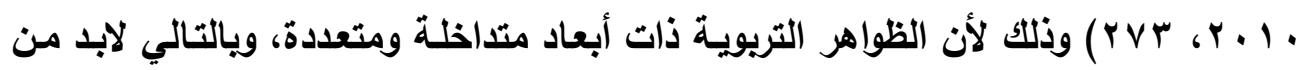
التأكيد على الأخذ بالمدخل المنظومي من إجراء البحوث التريويـة لتطوير المعرفة التريوية

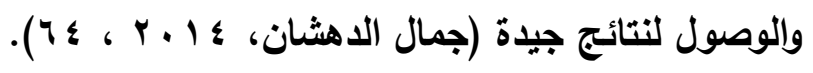




\section{تصور مقترح لسد الفجوة الرقمية لدى الباحثين التربويين كمدخل لتطوير المعرفة التربوية.}

1 - 1 ضـرورة الاهتمـام بتكنولوجيـا التعلـيم والـتعلم الرقميـة الحديثـة ومـا يـرتبط بــلك مـن سياسات وتشريعات وضرورة مراجعة البنية التحتية لمؤسسـات التعليم إضـافة إلى بذل

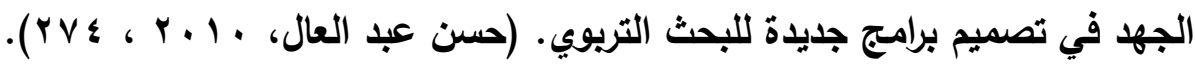
r ا - تلني حال التعليم المصري في جميع المؤثرات الدولية وذلك وفقا للتقارير الدولية ، ومن أهم دلالات تلني حاله عدم إعطاء التعليم الأولويـة في الإنفاق عليه ، وتراجـع دور الاولة في مسئوليتها تجاه التعليم ، وتلنيترتيبه بين الأنظمـة التعليمية الأخرى ، وتردي مستوى جودته ، وتدني المساواة في التعليم وارتفاع الحرمـان من التعليم .( أحمد الزنقلي

$$
(1196,4.196
$$

ويضـاف للاك أن تلني حال التعليم في مصر هو إنعكاس لتدني حال المعرفة التريويـة وفشلها في تطوير التعليم أو حتى حل مشكلاته المتراكمة والتس تزداد بشكل تدريجي ، ومستواه يتردى بشكل مستمر وسريع خاصة في السنوات الأخيرة . r ا - ضعف الاهتمام في إجراء البحوث التريوية بالبحوث والدراسات البينية وذلك للجمع بين أكثر من تخصص نظرًا لتكامل ووحدة المعرفة في عالم مجتمع المعرفة وعدم الفصل بين

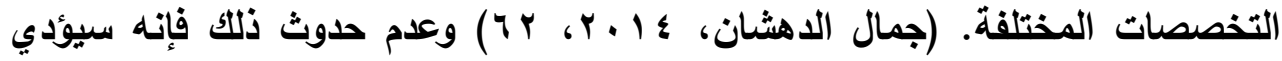

$$
\text { لعدم تطور المعرفة التريوية. }
$$

ع ا - ضـف الاهتمـام بـالبحوث النوعيـة أو الأثنوجرافيـة في المجال التربوي وضـف مهارات البحث النوعي لـدى أعضـاء هيئة التـريس والبـاحثين ، ممـا يستوجب أن تقوم كليـات التربيـة بإكسـاب البـاحثين وطـلاب الدراسـات العليا بهـا كمهـارات البحث النوعي (جمـال

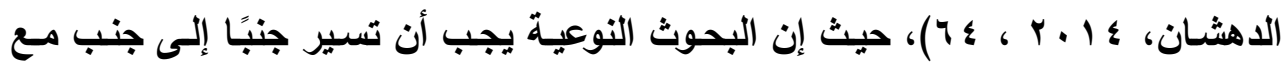
البحوث الكمية لأنها تصلح لاراسة موضوعات ومشكلات تربوية بشكل فعال. ه ا - إن مجتمـع المعرفة التريويـة بقدر مـا هو مجتمع ذكاء وإبداع لكنهـه يؤكد على ضرورة تعلم مهارات التفكير العلمي وأساليب البحث العلمي التربوي وتجهيز المعلومـات لاستجلاء

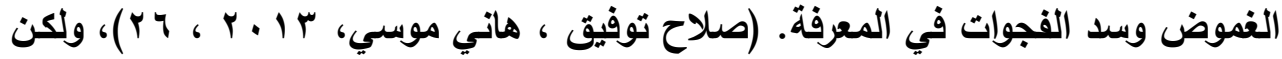


تصور مقترح لسد الفجوة الرقمية لدى الباحثين التربويين كمدخل لتطوير المعرفة التربوية.

هناك معرفة علمية متكررة بشكل كبيز مما يستدعي عمل خريطة بحثية لإجراء البحوث التريوية على مستوى مصر والتوطن العريي حتى لا تتكرر الجهود ويالفعل تسد الفجوات المعرفية الأكثر أهمية على المستوى المحلي والقومي والعالمي وتوظف في ذلك إمكانيات المجتمع الرقمي المتاحة.

7 ا 1 - تضيف الدراسـة إلى الدواعي السـابقة ضعف محتوى المعرفة التريويـة المصرية بصفة خاصـة والعربيـة بصفة عامـة في العصر الرقمـي والمتـاح على شبكة الإنترنت وهيمنـة محتوى المعرفة التريوية الأجنبية وضعف تواجد المعرفة التي باللغة العربية بسبب ضعف عمليات التواجد على المجتمع الرقمي بسبب ضعف قرات الباحثين في التعامل مـع العالم الرقمي ونشر أعمالهم إلكترونيًا. V ا - وترى الدراسـة الحاليـة من أهم الضروريات لتطوير المعرفة التربويـة وأهمها التواصل بين الباحثين وإلتربـويين والممارسين بالمـارس و صناع السياسـة التعليميـة ، وذلك في ضوء نتائج دراسة أعدت كدراسة تقيمية للقمة العالمية لتكنولوجيا المعلومات والاتصالات ICT التريوية جمع بين الباحثين التريويين والممارسين بالمدارس وصناع السياسـة وعقدت في لاهـاي ويساريس وواشنطن ويـانكوك وأسـفرت عن تواصـل الجهات الثلاثـة مسن بـاحثين وممارسـين وصناع السياسـة ممـا أدى إلى تطوير المعرفة وحدوث تعـاون مستمر أدى لخلق ونشر وتطوير المعرفة التريويـة ، والمعرفة التي تم إنشاعؤها في السنوات الأخيرة (Lai, K. W. et al. , 2016, كانت تستخدم في عدة مؤسسات محلية وإقليمية ودولية $.5-15)$ ونظرًا للـاواعي السـابقة لابــ من العـل على تطوير المعرفة التريويـة ويشكل تلدريجي ومستمر حتى تواكب العصر الرقمي 


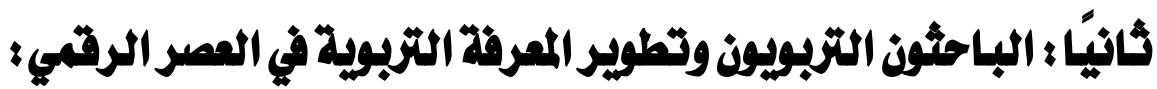

ولكي يحدث من تظوير المعرفة التربوية لابد من تطوير الباحثين التريويين لأنهم هم عماد

التطوير ومنتجي المعرفة التريوية وفيما يلي تناول ذلك بالتوضيح •

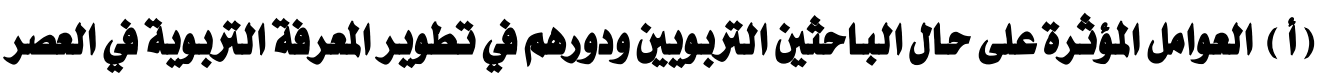

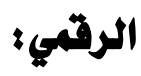

حتى يتم تطوير المعرفة التريوية في العصر الرقمي لابد من مواكبته والاستفادة منهـ في كليـات التربيـة ومراكز البحوث التريويـة المختلفـة وفي دور النشر التريويـة وغيرهـا ممن يتعلق بالمعرفة التريويـة وإنتاجها ونشـرها في مصر وحتى يتم تطوير المعرفة التريويـة في العصر الرقمي لابد من تطوير جميع مكونـات المنظومـة التربويـة حتى تواكب العصر الرقمي وتستفيد من كل إمكاناته في إنتاج المعرفة التريويـة المتجددة والصالحة للتطبيق على أرض هل الواقع والتـي ترتقي بالممارسـات التربويـة في التعليم المصـري وتحسن صسورته بين النظم

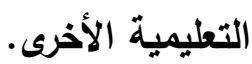

وتعد العمالـة العلمية ومدى تأهيلها هو العامل المؤثز على البحث العلمي ونتائجها. حيث ينخفض عدد المؤهلين للعمل في البحث العلمي بالإضافة إلى عدم وجود برامج التأهيل والتدريب التـي تتناسب مـع متطلبـات العصر ومدى التقدم الحاصل في العـالم في مجـالات

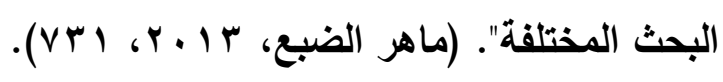

ويالتالي فإن أهم عنصر في تطوير المعرفة التريويـة هو الباحثون التريويون وكيفية إعدادهم للتعامل مع العصر الرقمي والتقتيات الرقمية وتوظيفها في جميع مراحل إعداد البحث التريوي حتى يصل إلى إنتاج معرفة تريويـة جديدة مفيدة وصـالحة للتطبيق على أرض الواقع ومساهمة في تطوير الممارسـات التربوية وحل مشكلات التعليم المصري وتحسين حاله بين

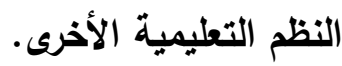


ويعد حال ومستوى الباحثين التريويين هو المحدد الرئيسي لحال المعرفة التريويـة

وهو الذي يحدد مدى تطويرها والارتقاء بها وكلما ارتقى مستوى الباحثين التربويين أدى ذلك لتطوير المعرفة التريوية والارتقاء بها، وهناك عدة عوامل تؤثثر على حالة الباحثين التربويين وقدراتهم البحثية ومن ثم تؤثر على المعرفة التربوية ومدى تظورها وهي ما يلي:

\section{1}

يوجد من الباحثين التريويين نوعين هما الباحثون العاملون بكليات التربية ومراكز البحوث التريوية ، النوع الثاني هو الباحثون التريويون من الخارج وقد يكونوا من المعلمين والعاملين بالتربية والتعليم أو الجهات الأخرى والنوع الأول من الباحثين التريويين من داخل كليات التربيـة فإنـه يتم اختيارهم لشـل وظيفة معيدين بنظام التكليف وجميعهم تم إعدادهم بالنظام التكاملي أي دارسة المقررات الأكاديمية وإلمقررات التريوية في آن واحد بشكل متكامل ويـتم اختيـارهم حسب المجمـوع التراكمـي طـوال سـنوات الاراسـة بالمرحلـة الجامعيـة الأولـى (Capraro, R. M. \& Thompson, B., البكالوريوس - الليسانس) ، وترى دراسـة (ان) (2008, 247 - 253 أن عملية اختيار الباحثين التريويين الذي سيعملون كأعضاء هيئة تدريس وياحثين تريويين يجب ألا يقتصر اختيارهم على أساس معدلاتهم العالية في مرحلة البكـالوريوس أو الليسـانس وإنمـا لابــ أن يوضـع في الاعتبـار مـدى خبرتهم في العمل في التدريس بالمدارس من الصف الأول حتى الصف الثالث الثانوي (12 - 1) وذلك لأن الباحث التريـوي المـتمكن هـو الـذي عمـل فتـرة بالتـدريس بالمــارس وتعـرف على الواقـع التربـوي

$$
\text { ومشكلاته واكتسب خبرات تريوية من ذلك. }
$$

النوع الثاني من الباحثين التربويين ممن يقوموا بالالتحاق بالاراسـات العليا بكليات التربيـة فإنـه يتم اختيـارهم ممن أتمـا دراستهم بالدبلوم الخـاص في التربيـة وتختلف شروط قبولهم من كلية إلى أخرى فمثلا في بعض الكليات مثل كليات التربية بسوهاج وجامعة أسيوط فإنها يتم اختيـارهم بالجامعة بشرط أن يكون حاصل على تقدير جيد في المرحلة الجامعية الأولى، و أن يكون قد حضر السينمار العلمي لمدة فصل دراسي كامل على الأقل وأن يكون 
أعد قراعات في مجال التخصص التربوي الذي ينوي الالتحاق بـه وفي الآونـة الأخيرة يمكن للطالب الحاصل على تقدير مقبول في المرحلـة الجامعية الأولى الالتحاق بالدراسـات العليا بشرط تعويض ذلك بمقررات تكميليـة لتحسين مستواه العلمي ، وتكون الأولويـة في قبول الباحثين للقيد للأعلى منهم في مجموع الدبلوم الخاص في التربية ، ويضاف إلى مـا سبق أن بعض كليات التربية تطلب بالإضـافة للقراءات باللغة العربية قراءات أخرى باللغة الإنجليزيـة كشرط للقيا بأقسام تلك الكليات. يلاحظ من شروط القيا للباحثين من الخارج لمرحلة الماجستير وكذلك طريقة اختيار المعيدين تخلو تمامًا من أي شروط توضح مدى إتقان الباحثين للمهارات والقدرات المطلويـة لمواكبـة العصـر الرقــي مثـل إتقـان اللغـة الإنجليزيـة أو الحصـول على شـهادة ICDL أو شهادة المواطن الرقمي وغيرها مما يثبت إجادته التعامل مـع تقتية المعلومـات الحديثة التي سوف تفيد في بحثه العلمي وتحسن من مستواه البحثي في المكتبات الرقمية وينوك المعرفة وغيرها من مصادر المعرفة العالمية والعربية. r - إعداد الباحثين التزبوبين في المصر الرقيمي؛ يمر إعداد الباحثين التربويين في الوقت الحالي بعدة خطوات هي ما يلي: - المرحلحالجامعية الأولى: ويتم فيها إعداد الباحثين إما بالنظام التكاملي بكليات التربية ثم تليها الدبلوم المهني في التريبة ثم الدبلوم الخاص في التربية، وإمـا أن يكون الباحث قد تم إعداده بالنظام التتابعي وهو حصوله على مؤهل جامعي غير تربوي ثم الحصول على الدبلوم العام في التربية. - مرحلة اللدراسات المليا: ثم يليه بعد ذلك الحصول على الدبلوم الخاص في التربية، وهذا النظام معمول به بكلية التربية بجامعة سوهاج ويعض الكليات الأخرى مع وجود فروق بسيطة بين الكليـات الأخرى في نظام الدبلوم المهنـي أو الـابلوم الخـاص ، ويتم التحاق البـاحثين بمرحلة الماجستير ثم يليها مرحلة الدكتوراه بعد الحصول على الدبلوم الخاص في التربية. 
ولقد اهتمت دراسـة (193 - Diezmann, C. M., 2005, 181 بدراسـة واقع

إعداد الباحث التربوي في مرحلة مـا قبل الذدمة أثتاء إعداد المعلمين بالمرحلة الجامعيـة الأولى وأوضحت أهمية تطليم الباحث التربوي وإعداده كباحث في مؤسسات إعداد المعلمين

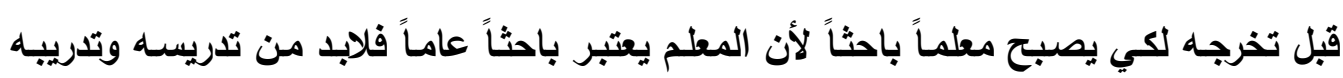
على مهارات البحث العلمي قبل التخرج حتى يستطيع عندما يصبح معلم أن يبحث في حلول للقضايا والمشكلات التريوية التي تواجهه في العمل أي الهدف من إعداد المعلم الباحث أن

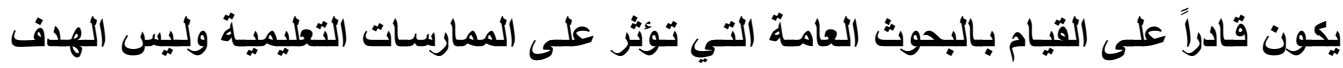

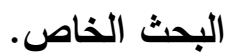

وتثـير الثـواهد على أن البـاحثين التربـويين قد تـم تكوينهم تريويًا في المرحلـة الجامعية الأولى في مرحلة الداسات العليا بثكل متلني إلى حد كبير ، وهذا مثلما حدث في معظم التخصصات الجامعيـة الأولى ، والذي تثثير إليه نتائج العايد من الاراسـات المتعلقة

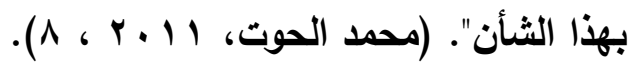
وأن وجود مثكلات في البحث التربوي في مصر وضعف مخرجاته قد يرجع إلى ضعف مستوى الباحثين التريويين في المرحلة الجامعية الأولى ومرحلة الاراسات العليا، "وقد يرجع تدني مستوى الإعداد التربوي للتربويين إلى عدم الجدية في تطوير المقررات التريوية

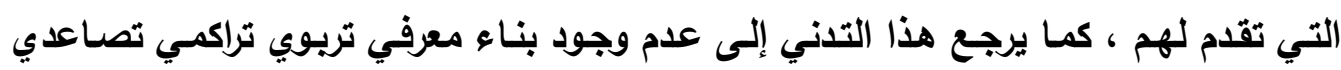

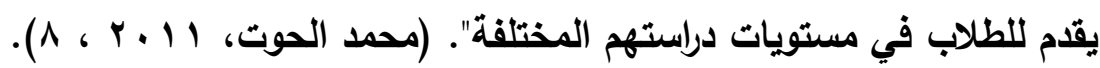
يضاف إلى ما سبق عدم وجود توحيد للوائح الإعداد التريوي بكليات التربية في مصر

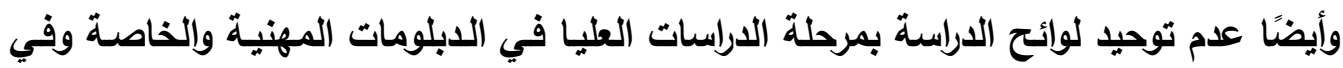
مرحلة الماجستير ومرحلة الدكتوراه، ومن ثم تباين جودة وكفاءة الباحثين التربويين وإنتاجهم التربوي من مكان لآخر ومن جامعة لأخرى ، وذلك بالرغم من وجود معايير قومية لجودة

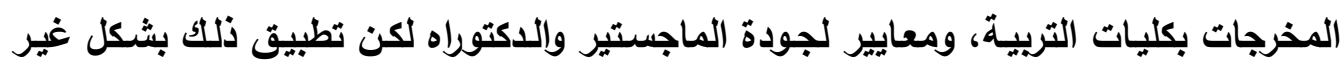
صارم، بالإضافة إلى أن غالبية كليات التربية في مصر غير معتمدة. 
يضـاف إلى مـا سبق عدم مواكبة المقررات والمنـاهج التي يلرسـها الباحث التربوي

للتقدم العلمي والتكنولوجي الذي يجب أن يتماشي مـع العصر الرقمي الذي يعيش فيه الآن، ويضاف لذلك قلة الإمكانات المادية المتاحة بكليات التربية والتي تلزم الباحثين التربويين ،وقد أوضحت دراسـة (Diezmann, C.M., 2005, 189) أن من أهم عوامـل إعداد الباحث التربوي قبل الخدمـة هو توفير البنية التحتيـة اللازمـة لذلك وتوفير الموارد المادية والمالية اللازمة لتدريبه على البحث التربوي.

ويضاف إلى ما سبق ضعف مستوى إعداد الباحثين في اللغة الإنجليزية التي تعد وسيلة مهمة للحصول على المعرفة المتاحة على الإنترنت لأن " الاحصائيات تثير إلى ان المواقع التي تنشر على صفحات الإنترنت يمثل منها (r Y \% من المواد باللغة الإنجليزيـة" (

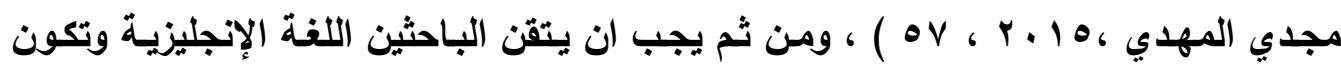
من اهم ما يدرسونه طوال سنوات إعداده بالدراسات العليا خاصة في هذا العصر الرقمي . وترى دراسة (Copraro, R . M. \& Thompson, B. , 2008, 247 - 253) بضرورة التأكيا على تعليم وتدريب الباحثين التريويين على المهارات التقتية لما لها من أهمية كبيرة في البحث التربوي في العصر الحالي. لابد أن يكون لاى الباحثين التريويين " إلمام بقضايا الأمن الرقمي و منها حماية الأجهزة و الثبكات ، حماية الأمن الثخصي مثل سرقة الهوية و التتبع عبر الإنترنت ، حيث أن نسبة كبيرة من الطلاب تفشل في حماية هويتهم عند استخدام البريد الاكتروني و

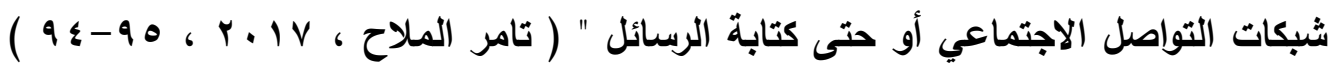
بالتالي لابد من إلمام الباحثين بذلك لحماية أنفسهم في العصر الرقمي . وترى الاراسـة الحاليـة أن إعداد الباحثين التريـويين في العصر الرقمي لابــ أن يتم عليه التطوير والتجديد ومن أهم انعكاسات العصر الرقمي على إعداد الباحثين التربويين مـا يلي: - إدخال التعليم عن بعد والمحاضرات الرقمية. 
- إدخال التعليم الإلكتروني بشكل كبير في الدراسات العليا. - الأنشطة الطلابية الإكترونية. - انتشار المكتبات الرقمية. - دخول الاختبارات الإكترونية في تقويم الطلاب. - انتشار النشر الإلكتروني للمعرفة التريوية.

- استخدام وتوظيف التكنولوجيا الدديثة في تدريس الباحثين التريويين وتدريبهم على استخد(مها. وتلك الانعكاسات تتطلب إعداد الباحثين التريويين بكليات التربية بطريقة تتناسب مع احتياجات العصر الرقمي .

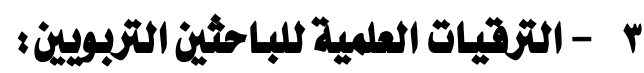

إن ترقيـة البـاحثين التريـويين وإنتاجهم التريـوي مـن أهـ العوامـل المـؤثرة على حـال المعرفة التريوية ومدى تطورها ، حيث إن هناك عوامل متعددة تؤثثر عليها منها مستوى إعداد الباحثين، الموضوعات المختارة للبحث العلمي ومعاير الترقيات المتغيرة وإجراءات عملها. ويعد الإنتاج العلمي المتظور الناضج هو الذي يتم إنجازه بعد درجة الأستاذية حيث النضـج العلمـي للباحث ولكـن "هـل الأسـتاذية هـي محطـة وصـول أم محطـة إقـلاع؟ وهـــه الإثـكالية تـؤثر على حال التريـويين ومعرفتهم التريويـة، حيث نـى غالبيتهم يتوقفون عن البحث العلمي بعد الحصول على اللقب ، برغم أنها المرحلة التي يتمتع فيها التربوي بلرجة أكبر مـن الحريـة الأكاديميـة ممـا يتيح لـه الفرصـة للإضـافة المعرفيـة ومـن ثم تحسين حـال

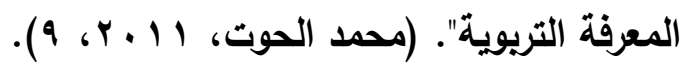
ويالتالي لابد من وجود آليات تشجع على ممارسة البحث العلمي بعد درجة الأستاذية ويمكن أن يتم ريط الإنتاج العلمي بعد الأستاذية واعتباره شرطًا لممارسـة المناصب الإداريـة حتى يستمر الإنتـاج العلمـي التربـوي وتتطور المعرفـة التربويـة خاصـة في عصر المعرفة 


\section{ع - أخلاقيات الباحثين التزبوينين في العصر الرقيي:}

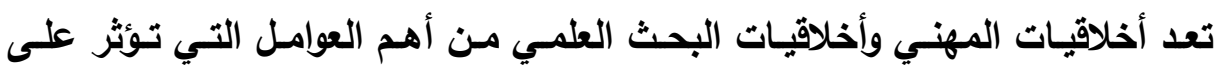
البحث العلمي، ويالتالي يجب على الباحثين التربويين التمتع بالأمانة العلمية والدقة والصدق التقات والاجتهاد والمثابرة في الحصول على العلم وغيرها من أخلاقيات البحث العلمي اللازمة لإكماله على أتم وجه والوصول لمعرفة تريوية جادة. وترى دراسـة (Delandshere， G. 2004) أن الباحث التربـوي لابــ أن يمتلكـ مجموعة من القيم الأخلاقية والمسئولية الأخلاقية والاجتماعية والسياسية ، وذلك يتطلب أن يكون موضوعياً ويراعي الصالح العام ويدرك خطورة ذلك. أما بالنسبة للعصر الذي نعيش فيه وهو ما يسمي بالعصر الرقمي حيث الانفتاح العلمي والتثفق المعلوماتي الوفير عبر الإنترنت والمكتبات الرقمية وينوك المعرفة وغيرها من

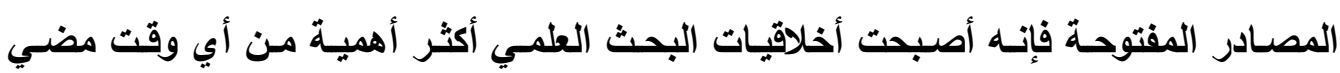
خاصة وأن تكنولوجيا المعلومات الديثة تؤثثر على النواحي الأخلاقية والقيمية لاى الباحثين

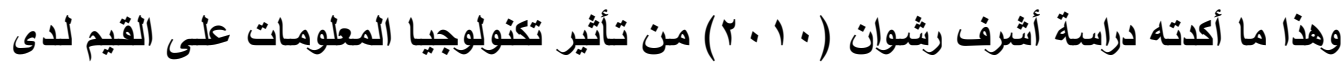
طلاب كلية التربية بالوادي الجليد. وتضيف دراسة (Schoorman , D. , 2017) إلى أن الباحث التربوي لابد أن يتمتع بالموضوعية والأمانة العلمية وأن يلزم بمباديء العدالة الاجتماعية في التعليم ويبتعد عن العنصرية وعدم التعصب لسياسة أو توجه معين أو مجتمع محلي معين.

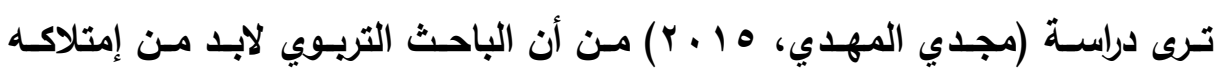

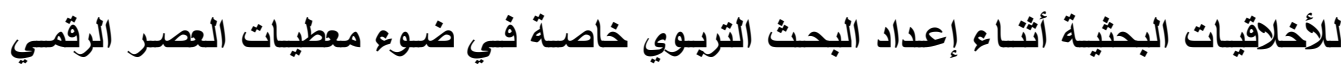
ويالتالي لابد من تمسك الباحث التربوي بتلك الأخلاقيـات البحثية في جميع مراحل البحث التربوي وعملياتهـ ، وأهميـة الأخلاقيـات للباحث التربوي في العصر الرقــي بصفة خاصـة

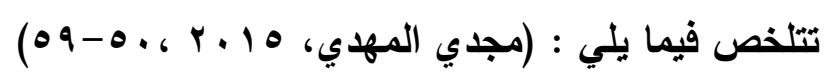




\section{تصور مقترح لسد الفجوة الرقمية لدى الباحثين التربويين كمدخل لتطوير المعرفة التربوية.}

- تعمل الأخلاقيات على زيادة فرص النشر الدولي للأبحاث وتؤدي إلى إرتفاع تصنيف

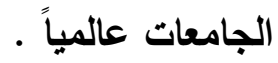

- الأخلاقيات هي أساس إدارة المعرفة التربوية في العصر الرقمي وتساعد على تنظيمها . - الأخـلاق تقلـل الفجـوة الرقميـة بـين الدول وتسـاعد في زيـادة التواصـل بـين البـاحثين

• التريويين

- الأخلاق تمكن الباحث من التعامل مـع المخـازن البحثية الرقمية ، وتسـاعد في تحقيق التكامل المعرفي التربوي الرقمي • - الأخلاقيـات تسـاعد في الحفـاظ على هويـة التخصص والمعرفـة التريويـة ، وتحــ مـن السرقات العلمية التربوية . - الأخلاقيات حاكم قوي للتسويق البحثي التربوي ، وتعمل على تمكين المعرفة التريويـة العربية في المكتبات الجامعية العالمية .

ويرى تامر الملاح (Y V r l أنه لابد من إلمام الباحثين التريويين بالقوانين الرقمية و هي تلك القوانين في المجتمع الرقمي التي تعالج مسألة الأخلاقيات الرقمية لفضح و معاقبة الاستخدام غير الاخلاقي للتكنولوجيا أو ما يسمى بالجرائم الرقمية أو الاكترونية الرقية ، حيث أن القانون الرقمي يعالج أربع قضايا أساسية (حقوق التأليف و النشر

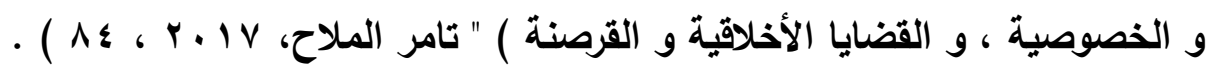
ومن ثم يجب أن يتم تسليح الباحثين بالقيم الأخلاقية اللازمـة للبحث العلمي وقد لاحظت الباحثة عدم وجود مقررات دراسية بكليات التربية سواء في المرحلة الجامعية الأولى أو مرحلة الدراسـات العليا خاصـة بغرس أخلاقيات البحث العلمي للدى الباحثين التربويين برغم من أهميتها في العصر الرقمي.

\section{(ب ) كثايات الباحثين التزبويمن اللازمة لتطوبر المعرفة التزبوية في العصر الرقيمي:} يجب على الباحثين التربويين التمتع بمجموعة من الكفايات اللازمـة لممارسـة البحث التربوي بصفة عامـة منها إتقان مهارات البحث العلمسي وخطواتـه ، وإتقان استخدام منـاهج 
البحث المختلفة في البحث التربوي والقدرة على إنجاز البحث التربوي بشكل علمي صحيح بداية من اختيار العنوان وتحديد المشكلة وجمع المـادة العلمية وكيفية دراسـة مشكلة الدراسـة حتى الوصول إلى النتائج بالإضافة إلى الأمانة العلمية والالتزام بأخلاقيات المهنة وتقبل النقد وامتلاك الدافعية لإتمام البحث التربوي والقدرة على التعلم المستمر. وعندما جاء العصر الرقمي وأثر على البحث التريوي بشكل كبير وتطلب من الباحثين ضرورة مواكبته وإتقان كل ما يلزم من معارف ومعلومات ومههارات لمواكبته. وفي حالة الرجوع إلى المعايير القياسية لبرامج الدراسـات العليا الصـادرة عن الهيئة القوميـة لضـمان الجـودة والاعتمـاد عـام 9 . . بـم تجــ أن أهـم مواصـفات خريجـي بـرامج الماجستير وأيضا خريجي برامج الدكتوراة أن يكون قادرًا على استخدام تكنولوجيا المعلومـات بمــا يخــدم الممارســة المهنيـة ، واســتخدام المصــادر المختلفـة للحصـول عـى المعـارف والمعلومات". (الهيئة القومية لضمان الجودة والاعتماد ، 9 . . ب، 11). ويلاحظ أن إتقان المهارتين السابقتين من أهم ما يجب أن يتم إعداد الباحث التربوي لإتقانهما لما لهما من أهمية في تطوير المعرفة التريوية. وأوضـت إحدى الدراسـات أن الكفايـات اللازمـة للباحثين في العلوم الاجتماعيـة في

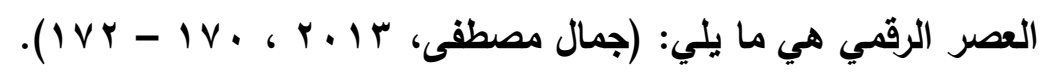
* الكثايات المعرضية: ومنها معرفة كيفية الاستفادة من منجزات العصر الرقمي في البحث العلمي في مجال تخصصه، ومعرفة معايير الحكم على البحث العلمي إلكترونيًا ومعرفة أهمية المكتبات الرقمية وقواعد البيانات في تيسير البحث العلمي ، معرفة محركات البحث التي تساعد في الحصول على البيانات، ومعرفة خصائص الملفات وأنواعها.

\section{* الكثايـاث الأداثيةح:}

ومنها القدرة على توظيف التكنولوجيا الحديثة في البحث العلمي والمشـاركة في

حلقات النقاش إلكترونيًا والقدرة على التعامل مـع المكتبـات الرقمية وقواعد البيانـات لتيسير 


\section{تصور مقترح لسد الفجوة الرقمية لدى الباحثين التربويين كمدخل لتطوير المعرفة التربوية.}

وتجويد البحث العلمـي والالتزام بأخلاقيـات البحث العلمسي في العصر الرقمي، والقدرة على إنثاء مدونة إلكترونية بحثية خاصة والتفاعل مع المدونات البحثية القائمة بالفعل. وتضيف إحدى الاراسات أن الباحث التربوي يجب أن يمتلك المقومـات التالية: (على

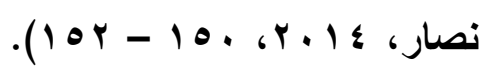

- القدرة على استيعاب التطورات السريعة والمتلاحقة في العصر مثل التعليم المفتوح والتعليم الافتراضي والتعليم الإكتروني. - فهم المعاني المستخدمة في مجتمـع المعرفة مثل عمال المعرفة، والتعلم الذاتي، والتعليم المستمر، والتعلم النشط والإلمـام بالتطبيقات المتجددة لتكنولوجيـا المعلومـات والاتصـال في المجال التربوي. - اكتساب مهارات التواصل العلمي على المستوى الدولي والقدرة على إقامـة علاقات علمية مع مراكز الأبحاث وغيرها من مؤسسات البحث الاولية. - اكتساب مهارات التعامل مع التطبيقات المختلفة لتكنولوجيا المعلومات في مجال البحث التربوي. - القدرة على المشاركة في أنشطة تقاسم المعرفة التريوية من خلال المنتديات والملتقيات الفكرية. - المهارة في التعامل مع مصادر المعرفة المختلفة في المكتبات الرقمية والورقية. - استخدام المنهجيات البحثية الحديثة لاستيعاب المستجدات العلمية في البحث التربوي مثل المنهج والمنهجية والاتجاهات الحديثة في المجال التريوي. وترى دراسـة أ خرى أن كفايات البحث العلمي لدى طلاب الدراسـات العليا في عصر اقتصــاد المعرفـة هـي الكفايـات الثخصـية، والكفايـات الأخلاقيـة، والكفايـات الأكاديميـة ،

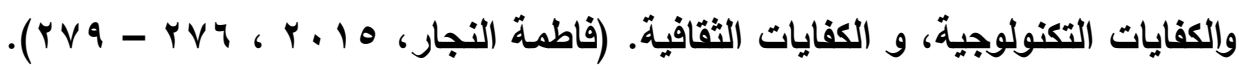


وهناك من يرى أن الباحث التربوي لابد أن يمتلك القدرة على نقد ذاتـه ونقد أفكاره والحكم عليها أو الثك الذتي وكذلك يمتلك القدرة على نقد الآخرين وأفكارهم والحكم عليها. .(Kerdeman, D., 2015, 719)

وتضسيف دراسـة (Schoorman, D., 2017, 116) إلى أن الباحث التريـوي بالإضافة إلى امتلاكه القدرة على النقد للأفكار لابد أن يكون مثقفاً بـل ومتعدد الثقافات حتى يستطيع التحليل والنقد الصحيح البناء الذي يسـهم في النهاية في إصلاح المجتمـع والتعليم وتحقيق العدالة الاجتماعية. وترى الدراســة الحاليـة بالإضـافة إلسى مـا سـبق أن الباحث التربـوي لابــ أن يمتلك مجموعة من الكفايات اللازمـة لتطوير المعرفة التريوية في العصر الرقمي وتقسمها الدراسـة الحالية إلى ما يلي: - الئ - كفايات الوصول والنفاذ إلى المعرفة التريوية . - كفايات استيعاب المعرفة التريوية. - كفايات تطبيق المعرفة التريوية. - كفايات إنتاج المعرفة التريوية. - كفايات نشر وتوزيع المعرفة التريوية. ويجب على الباحث التريوي الإلمام بكل الكفايات السـابقة وإتقانها حتى يستطيع أن يواكب العصر الرقمي ويطور المعرفـة التريويـة، لكن في حالـة عدم إلمامـه بتلك الكفايـات فسوف توجد لايه فجوة رقمية وهو ما سيتم تناوله في ذلك الجزء التالي من الاراسة.

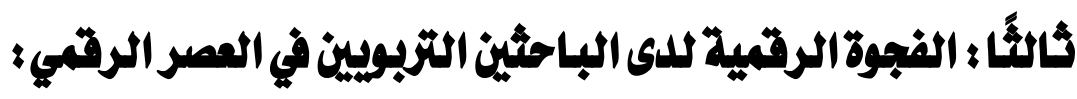

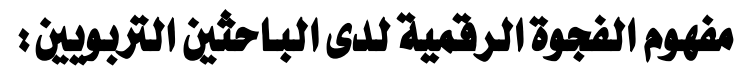


أن الفجوة الرقمية تسمي أم الفجوات أو الفجوة الأم "وهي كفجوة مركبة تطقو كما موضح بالثكل التالي فوق طبقات متراكمة من فجوات عدم المساواة تصب فيها بصورة

$$
\begin{aligned}
& \text { أو بأخرى وهي: (نبيل على، ونادية حجازي، ه . . r ، ب 1). } \\
& \text { - الفجوة العلمية والتكنولوجية. } \\
& \text { - الفجوة التنظيمية والتشريعية. }
\end{aligned}
$$

- فجوات الفقر : وهي فجوات الدخل والغذاء والمأوى والرعايـة الصحية والتعليم

والعمل.

- فجوات البنبـة التحتبة بسبب غيـاب السياسـات وعدم تـوفر شبكات الاتصـالات والقصور في تأهيل القوى البشرية.

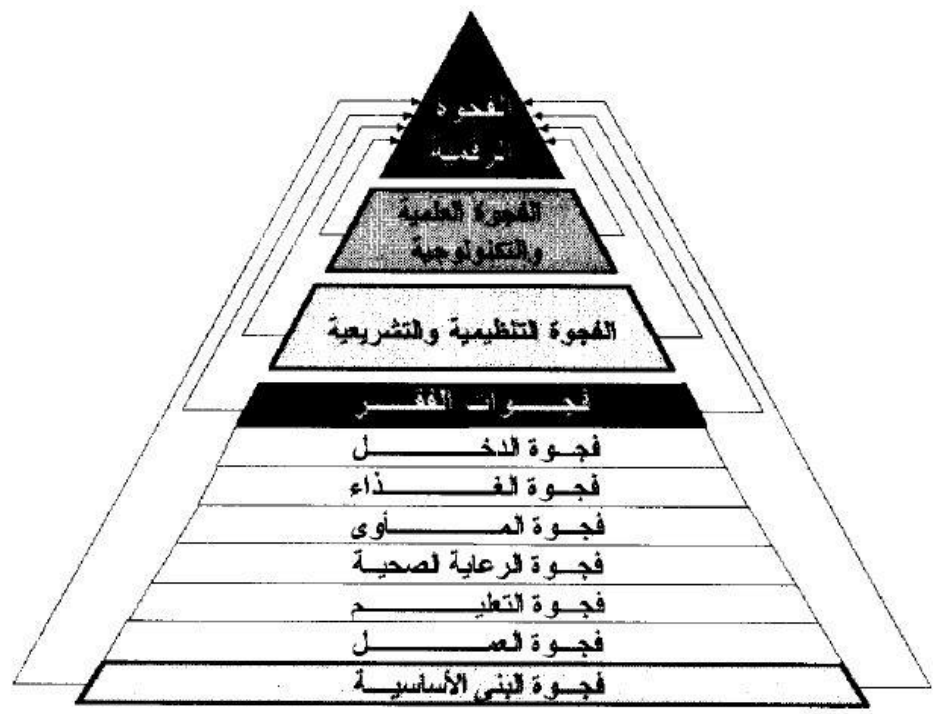

شكل رقم (1) - (1) - (1)

الفجوة الرقمية : فجوة الفجوات

يتضح من الشكل السابق تربع الفجوة الرقمية على قمة الفجوات فهي تستحق أن تسمي الفجوة الأم أوفجوة الفجوات لأنها نتيجة لكل الفجوات السابقة والموضحة بالشكل 
ومفهوم الفجوة الرقميـة لغويًا تكون مسن كلمـة الفجوة وهي تعنسي المتسـع بين

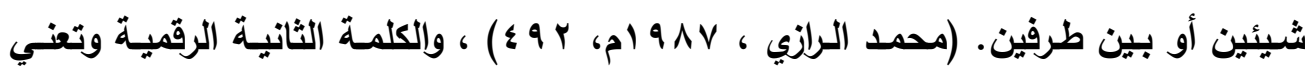

الرقمي أو الحسـي وهي التقتية السريعة لنقل المعلومـات ويكميات كبيرة وغير محدودة ،

أي أن تلك المعلومات تخزن وتنقل وتحول إلى شكل رقمي وتصل بسرعة كبيرة إلى الأجهزة

الحديثة تصل إلى بليون عملية حسابية في الثانية". Rutten, P. \& Poel, M. )

2002, 102)

ويعد مفهوم الفجوة الرقمية من المفاهيم التي ظهرت مـع التطور التكنولوجي، ولذلك

فهو مفهوم لـه عدة تعريفـات تختلف مـن مكان لآخر ومـن باحث لآخر وهو "مفهوم مـن المفاهيم المتغيرة والمرنة حيث تتعدد جوانبه، وتختلف من مكان جغرافي لمكان لآخر ومن

$$
\text { وقت لآخر". (Pena - Lopez,I., 2010, 3)، }
$$

وقد نشأ هذا المصطلح في الولايات المتحدة الأمريكية بسبب وجود فارق كبير بين المواطنين الأمريكيين في استخدام الحاسب الآلي والإنترنت، ثم انتشر هذا المفهوم بعد ذلك في بقية أنحاء العالم.

ومـن تعريفـات الفجـوة الرقميـة "تعنـي اللامسـاواة في إمكانـات النفـاذ إلى المعلومـات

والمساهمة فيها من حيث الإنشاء والإتاحة وكذا في الاستفادة من المعرفة والثبكات والأجهزة

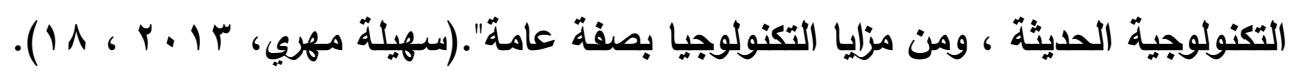
وتعرف الفجوة الرقمية بأنها "هي الفوارق التكنولوجية بين مجموعات الناس، وهي الفجوة الموجودة بين أولئك الذين لديهم إمكانية الوصول إلى المعلومـات والاتصال بالتقتيات وأولئـك الـذين لا يستطيعون ومنهـا "الفجـوة العالميـة" بـين دول العـالم والفجـوة بـين الأغنــاء والفقـراء "فجـوة اجتماعيـة" والفجـوة بـين مـن يستخدمون التكنولوجيـا في التواصل الاجتماعي والذين لا يستخدمون "فجوة ديمقراطية". (Rodrigo, M. M. T., 2005, 53) تُعرف الفجوة الرقمية: "بأنها الفجوة بين الأفراد والأسر والشركات والمناطق الجغرافية على مستويات اجتماعيـة واقتصادية مختلفة فيمـا يتعلق بكل من فرصهم في الوصول إلى 
تكنولوجيا المعلومات والاتصالات واستخد(مها للإنترنت بشكل كبير". Cruz, Jesus, F. et) al. , 2016, 72)

وتُعرف بأنها شكل جديـا مـن أشكال عدم المسـاواة الاجتماعيـة وهـي فكرة تقسيم الأفراد والأسـر على مختلف المستويات الاجتماعيـة والاقتصـادية، فيمـا يتعلق بفرصتهم في الوصول إلى المعلومات واستخدام تكنولوجيا المعلومـات والاتصالات. Korupp, S. E. \&) Szydlik, M. , 2005, 409) وما زال مصطح الفجوة الرقمية يكتنفه الغموض إلا أن هناك عدة تعريفات لمفهومها تتضح منطلقاتها إذا ما تناولها من منظور الدورة الكاملة لاكتساب المعرفة التي تثتثل على

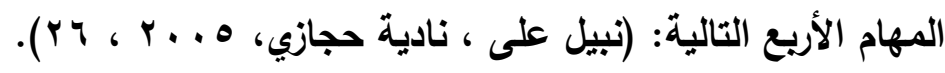

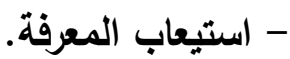
- النفاذ واللوصول إلى مصادر المعرفة. - توليد المعرفة الجديدة. - توظيف المعرفة القائمة. ويالتالي جاء تعريف (نبيل على ، ناديـة حجازي، ه . . ب) للفجوة الرقمية تعريفات

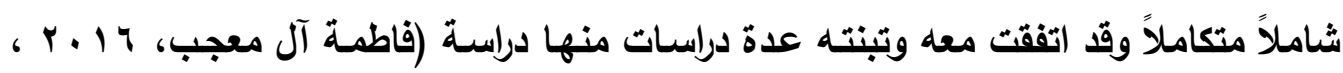

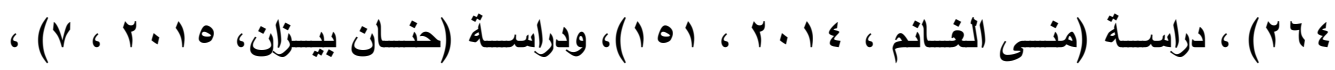

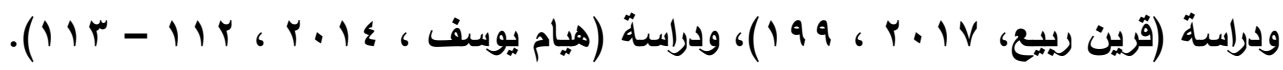
ويالتالي توجد ثلاث تعريفات للفجوة الرقمية من حيث تغطيتها لدورة اكتسـاب المعرفة

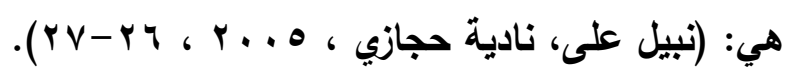

1 - تعربف ضيقا يحصر مفهوم الفجوة الرقمية في النفاذ إلى مصادر المعرفة من حيث مدى توفر البنية التحتية اللازمـة للحصول على مـارد المعلومـات والمعرفة، وهذا التعريف يركز على الفـروق في مـدى توفير شبكات الاتصـالات ووسـائل النفـاذ إليها ومـدى ريطها بالإنترنت. Y - تصريف أوسع: يشتمل بجانب النفاذ إلى مصـادر المعرفة استيعابها من خـلال التعليم والتدريب والتوعية ومدى توظيفها اقتصاديًا واجتماعيًا وثقافيًا. 
r - تعريف أشمل ؛ وهو يغطي الدورة الكاملة لاكتساب المعرفة فيشتمل على توليد المعرفة الجديدة من خلال مؤسسات البحث والتطوير . والدراسة الحالية تتفق مع التعريف الشامل للفجوة الرقمية وهو الذي يرى أن الفجوة الرقية هي الفجوة في النفاذ لمصادر المعرفة والفجوة استيعاب المعرفة وتوظيفها في الفجوة في توليد المعرفة الجديدة ، والفجوة في القدرة على نشرهاوتوزيعا ، أي هي الفجوة في تغطية جميع مراحل دورة اكتساب المعرفة. ومن ثم يمكن القول أن الفجوة الرقمية لدى الباحثين التربويين هي عدم المساواة الرقمية التي يترتب عليها الفجوة في الوصول والنفاذ إلى مصادر المعرفة التريويـة، والفجوة في استيعابها وتطبيقها في البحث التربوي، والفجوة في توليد وإنتاج المعرفة التريويـة الجديدة، والفجوة في القدرة على نشرها وتوزيعها محليًا وعالميًا.

\section{(ب) مستويات المجورة الرقمية وأبعادهاء}

للفجوة الرقمية عدة مستويات وتوجد عدة أراء حول مستويات الفجوة الرقمية فهناك

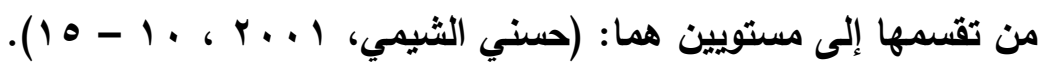

$$
\begin{aligned}
& \text { المستوى الأول: الفجوة بين الأفراد والطبقات: } \\
& \text { المستوى الثاني: الفجوة بين الدول. }
\end{aligned}
$$

توجد عدة تقسيمات للفجوة الرقمية فمنها من يميز بين القدرة المادية ويين القدرة المعرفية على النفاذ ومن ثَم يظهر مستويين للفجوة الرقمية هما: (فاطمـة أل معجب، 17 ـ ب،

$$
\text { - التفاوت في القدرة على النفاذ والوصول الرقمي. }
$$

- التقاوت في الإلمام بمهارات استخدام تكنولوجيا المعلومات والاتصالات.

وترى دراسـة (Rao, S. S. , 2005) وهي دراسـة عن جهود سد الفجوة الرقمية بالهند أن للفجوة الرقمية أبعاد ومستويات حسب المستوى الاقتصادي للأفراد، وحسب الازدهار الاقتصــادي للـدول، وحسب العِرْق ، وحسب العــر (صـير - كبيـر) ، وحسب المنــاطق 

الجغرافية (ريف ، حضر) وحسب الجنس (إناث - ذكور)، وهذه المستويات للفجوة الرقمية من حيث النوع والارجة في الاتصال الهاتفي والقدرة على الوصول إلى المجتمع الرقمي والإنترنت ، و أن الفجوة الرقمية لها مستويات منها فجوة رقمية عالمية ، فجوة رقمية إقليمية ، فجوة

رقمية وطنية.

وهناك رأي آخر يقسمها إلى خمس مستويات هي: (حمزة بعلى ، وآخرون، 1 . . r ،

$$
\cdot(r+r-r \text {. }
$$

- الفجوة الرقمية بين أفراد الأسرة. - الفجوة الرقمية بين الجنسين. - الفجوة الرقمية بين الجهات. - الفجوة الرقمية بين الأجيال. - الفجوة الرقمية بين الدول المختلفة. وتضيف دراسة (Tien , F.F. \& Fu, T.- T. 2008) إلى أن هناك فجوة رقمية بين الأفراد وفقًا للمستوى الاقتصادي، والاجتماعي، وكذلك العرقي ، وهنالك فجوة رقمية بين طلاب الجامعات الحكومية وطلاب الجامعات الخاصـة، وفجوة رقمية بين طلاب التخصصات في العلوم الاجتماعية والعلوم الطبيعية والهندسية. وترى دراسـة (Korupp, S. E. \& Szydlik, M. , 2005, 409) أن الفجوة الرقميـة مســتويان المسـتوى الرقـــ الأول وهـو مسـتوى الوصـول إلـى أجهـزة الكمبيـوتر والإنترنت، والمستوى الرقمي الثاني هو استخدام تلك التقنيات في العصول على المعارف وإلمعلومات والتعامل معها. وهناك من يرى أن للفجوة الرقمية عدة مستويات هي: (نبيل على ، نادية حجازي ، ه ... ؟، (Mcphail, T. L., 2009, 126) ، $r V$

- مستوى القطاع الخاص. - مستوى القطاع الأهلي - مستوى الدولة عامة.
- مستوى الأفراد. - مستوى القيادات. - مستوى الجماعات. 


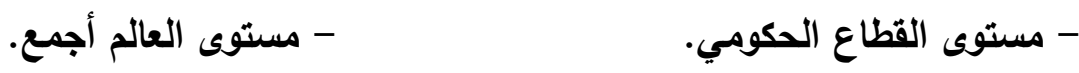

يتضح مما سبق وجود عدة مستويات للفجوة الرقمية وأهمها التي توجد بين الأفراد

ويين الجنسين ويبين الجهات واللدول المختلفة ممـا يؤثثر بشكل كبير على جميع النواحي

الأخرى خاصة النواحي المعرفية منها.

* أبعاد المجموة الرقيمية

لقد بلور تقرير التنمية الإنسانية لعام Y . . Yم، أبعاد الفجوة الرقمية في محورين

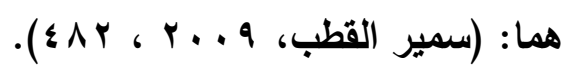

- المحور الأول (الأفقي): محور الاورة الكاملة لاكتساب المعرفة والتي تشمل خمس مراحل هي: النفاذ إلى المعلومـات وتنظيم المعلومـات وإتخلاص المعرفة وتطبيق المعرفة، وتوليد المعرفة الجديدة. - المحـور الثاني (الرأسـي): محسور العناصـر الأساسية لإقامـة صـناعة المعلومـات وتشـتمل على عنصـر محتـوى المعلومـات، وعنصـر معالجـة المعلومــات، وعنصـر توزيـع المعلومات ويمثل عنصر المحتوى أهم هذه العناصر الثلاثة. (برنامج الأمم المتحدة الإنمائي $\cdot(r)$, r...r.

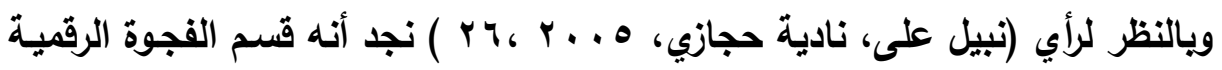

للأبعاد التالية: - 20 - 20

$$
\text { - }
$$

ومن ثم يتفق هذا التقسيم لأبعاد الفجوة الرقمية مع تقسيم تقرير التنمية الإنسانية

عام r · . . ، الأي يرى أن أبعاد الفجوة الرقمية هي التي تعطي دورة اكتساب المعرفة .

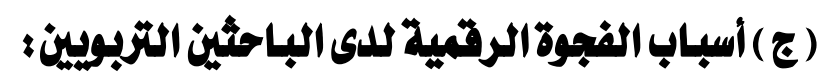

أسباب متعددة أسباب الفجوة الرقمية لاى الأفراد بصفة عامة والباحثين التريويين

بصفة متعددة ، وترى دراسة (Cruz - Jesus, F.et al., 2016, 72) أن السبب الرئيسي 
تصور مقترح لسد الفجوة الرقمية لدى الباحثين التربويين كمدخل لتطوير المعرفة التربوية.

للفجوة الرقمية هو اللامساواة الرقمية بين السكان والتي ترجع لعوامل اقتصادية واجتماعية وعرقية وسياسية.

للفجوة الرقمية أسباب ترجع للاختلافات الدولية وإلاخلية بين المنـاطق ويبين الأفراد منهـا الاختلافـات في المجـال الاجتمــاعي، والمجـال الاقتصـادي ، والعوامـل التكنولوجيـة ، والعوامل اللغويـة، ومدى امتلاك البنيـة التحتيـة ومستوى التعليم وإكتسـاب مهارات الاتصـال والموقع الجغرافي والجنس والمرحلة العمرية. Chen, W. \& Wellman, B. , 2004, 18 - 25)

وترجيع دراسـة ( Fuchs, C.\& Horak,E.,2008,101) أسباب الفجوة الرقمية إلى وجود أريع فجوات في المجتمع هي الفجوة الاجتماعية ، والفجوة الاقتصادية ، والفجوة السياسية والفجوة الثقافية.

إن من أهم أسباب الفجوة الرقمية عدم المساواة بجميع أشكاله في عدة عوامل وهي

العامل الأول : وهو مدى التوفر الجغرافي والنواحي الماديـة للمستخدم وتوفر البنية التحتية المادية (السلكية واللاسلكية) والتطبيقات والأجهزة المنزلية. العامل الثاني: هو الوصول المالي ويتمثل في القدرة الاقتصادية على الدفع باستمرار من أجل خدمات تكنولوجيا المعلومات والاتصالات التي يحتاجها المستخدم . العامل الثالث :هو العامل المعرفي ومدى توفر القدرة والمهارات اللازمـة لاستخدام تكنولوجيا الاتصالات والمعلومات وذلك يرجع للنظام التعليمي ودور المناهج الدراسـة المختلفة في ذلك. (Herselman, M. \& Britton, K. G. , 2002, 271) وترى هذه الاراسة في نتائجها أن القجوة الرقمية لدى المتعلمين والطلاب هي فجوة تعليميـة ترجـع أهـم أسبابها إلى التعليم الذي يجب أن يدرسـهم كيفيـة استخدام تكنولوجيـا المعلومـات والاتصـالات التي تعتبر جانبـاً مهــاً من جوانب حياتـا وأنها تغير الطريقـة التي نؤدي بها أعمالنا والطريقة التي نعيش بها والطريقة التي نتعلم بها في هذا العصر الذهبي للتكنولوجيا. (Herselman, M. \& Britton, K. G. , 2002, 270) 
تـرى دراســة ( Korupp.S.E\&. Szydlik,M.,2005,409 ) أن رأس المـال

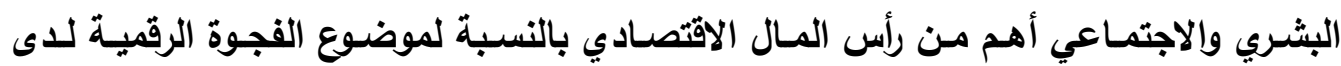

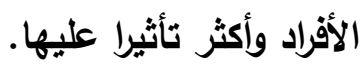
تـرى هذه الاراســة أن أهـم أسباب الفجـوة الرقميـة هـو عدم المســاواة الاجتماعيـة

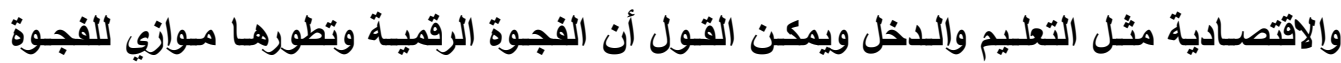

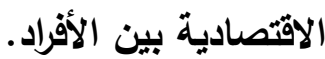
- هنـاك أسباب ترجع لرأس المـال البشـري خاصـة في المنـاطق الريفيـة المتخلفـة تعليميًا وضرورة محو الأمية الرقمية لاى سكان الريف.

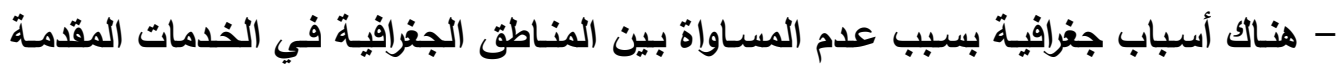
لها. - هناك أهمية كبيرة للعرق في الفجوة الرقمية، وكنلك الجنس، فالخلفية العرقية ونوع الجنس مهـة في تحليل ودراسة الفجوة الرقية. , Korupp, S. E. \& Szydlik, M. , 2005) 410) هناك رأى يرى أن أسباب الفجوة الرقمية هي خاصة بالتعليم الجامعي ترجع للأسباب

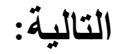
أسباب فردية: تتصل بالمتطلم ومدى اكتسابه مهارات استخدام تكنولوجيا المعلومـات والقدرة على التواصل عبرها. أسباب مؤسسية: ترجع للمؤسسة الجامعية ومدى توافر إمكاناتها المادية و البنية التحتية بها. أسباب وطنيـة: وتتعلق بمستوى الاولـة وكذلك إمكاناتها الماديـة وسياسـاتها ومدى تبنيها لذلك.

(Khalid, Md. S. \& Pedersen, M. J. L. , 2016, 220 - 221) 
ويمكن القول أن للفجوة الرقمية أسباباً متعددة اتفقت عليها عدة دراسات هي دراسة

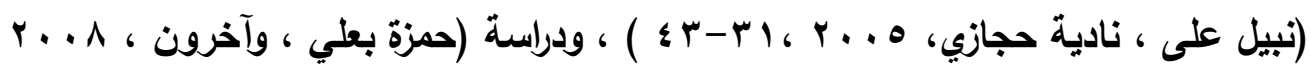

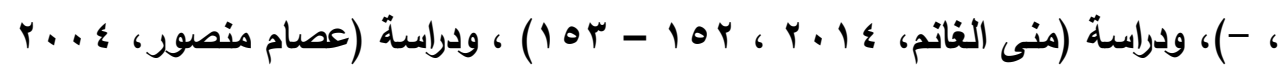

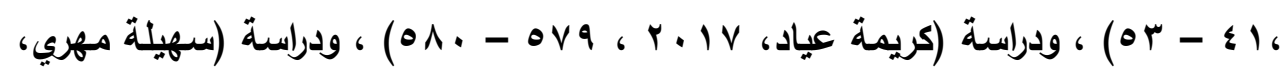

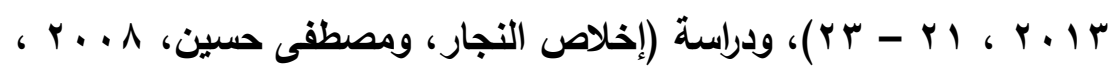

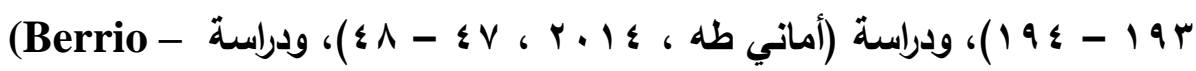
(Rao, S. S. , 2005, ودراسة Z Zapata, C. \& Rojas, H. , 2014, 133 - 142) 361 - 375) ودراسة (Naidoo, S. \& Raju, J. , 2012) ودراسة (حميد

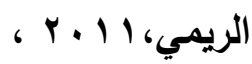

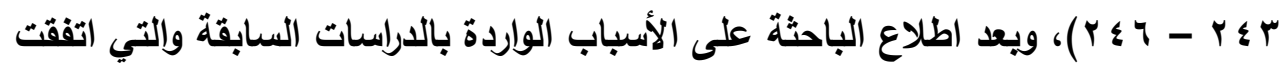
عليها هذه الدراسات فإنه يمكن القول أن أسباب الفجوة الرقمية هي:

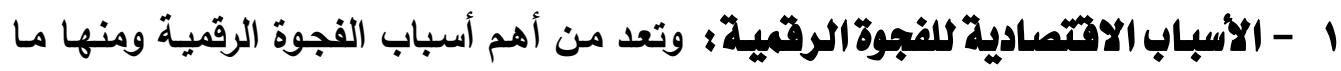
يلي: - ارتفاع تكلفة توطين تكنولوجيا المعلومات. - كلفة الملكية الفكرية ضعف البنية التحتية اللازمة. - تكتل الكبار والضغط على الصغار. - التهام الشركات متعددة الجنسيات للأسواق المحلية. - اتحياز تكنولوجيا المعلومات إلى القوى على حساب الضعيف. Y - الأسباب التكثولوجية: وتئمثل فيما يلي: - تنامي الاحتكار التكنولوجي. - سرعة التطور التكنولوجي.

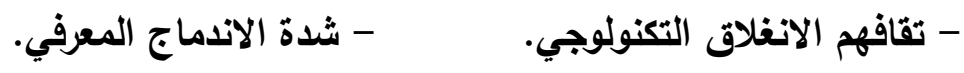

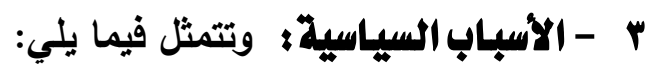
- غياب سياسات المطلومات بالدول النامية. 

- سيطرة المنظمات العالمية وانحيازها لصف الكبار . - احتكار الولايات المتحدة الأمريكية للمحيط الجيومعلوماتي. - سيطرة الحكومات بالدول النامية على الوضع المعلوماتي بها. ع -الأسباب الثقافية والاجتمامية؛ ومنها ما يلي: - تدني التعليم وعدم توافر فرص التعلم وضعف دوره. - انتشار الأمية بكل أنواعها خاصة الهجائية والإكترونية. - الفجوة اللغوية خاصة في اللغة الإنجلية.

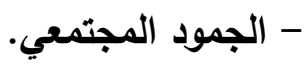
- الأسباب العرقية والعنصرية. - الجمود التظيمي والتشريعي والمشكلات التظيمية. - غياب الثقافة العلمية والتكنولوجية. - عدم وجود العدالة والمساواة الاجتماعية بين المناطق الجغرافية. كان ذلك عرضاً موجزاً عن أسباب الفجوة الرقمية في المجتمع بصفة عامـة أمسا من أسباب الفجوة الرقميـة لـى البـاحثين التربويين فهي لا تختلف عن أسباب الأميـة الرقمية بالمجتمع بالإضافة إلى بعض الأسباب التي قد ترجع لبعض الخصائص الأتية أو الشخصية للباحث التريوي أو إلى ظروفه الاقتصادية والاجتماعية وطرق اختياره وطرق إعداده. ويمكن القول أن من أهم أسباب الفجوة الرقمية لدى الباحثين التريويين ما يلي:

\section{ا}

من أسباب الفجوة الرقمية لدى الباحثين ارتفاع تكلفة اقتناء التقنية الحديثة وأجهزتها وارتفاع تكلفة الإنترنت في مصر مقارنـة بدخل الباحثين الذي يعتبر محدوداً للغاية ولا يفي بمتطلباتهم الحياتية مما يجعل هناك صعوية في مواكبتهم للتقدم التكنولوجي وإقتناء أجهزته، بالإضـافة إلى ضـعف توفر تلك الخدمات أيضًا بالجامعـات ويكليـات التربيـة لارتفـاع التكلفة 
تصور مقترح لسد الفجوة الرقمية لدى الباحثين التربويين كمدخل لتطوير المعرفة التربوية.

وضعف ميزانية تلكك الجامعات وكلياتها ممـا يُضعف البنية التحتية بتلك الكليات ويؤدي إلى زيادة الفجوة الرقمية لدى الباحثين التريويين.

r - الأسباب التكثولوجية: r

حيث التطور التكنولوجي المتلاحق والذي لم يتم إعداد الباحثين بشكل جيد لمواكبته حيث ينقص العديد منهم المهارات والقدرات اللازمة لاستخدام التكنولوجيا الديثة ويستلزم ذلك تطوير البنية التحتية بالجامعات وتزويدها بتكنولوجيا المعلومات وتدريب الباحثين التربويين أنثاء فترة إعدادهم عليها. r

حيث تدني مستوى تعليم الباحثين التريويين فيما يخص الاهتمام بالتكنولوجيا الحديثة باية من مرحلة التعليم الأساسي وحتى التعليم الجامعي ونقص المهارات اللازمـة للتعامل مـع تكنولوجيا العصر، وضعف مستوى اللغة الإنجليزية الذي يعد من أهم المداخل في استخدام تكنولوجيا المعلومات والاتصالات ونقص الوعي المعلوماتي لاى الباحثين التريويين.

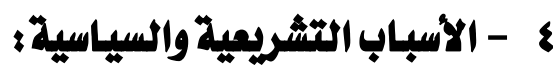

وتتلخص في ضعف تبني السياسات العامة بالمجتمع للتكنولوجيا الحديثة في تحقيق النمـو المعرفي وتحقيق التنميـة في جميع المجالات، ونقص التشريعات بالجامعات ونقص الحريـات التي تجبر الباحثين على إتقان كل مـا يخص التكنولوجيا الحديثة وتوظيفها في البحث العلمي ، وقد بدأ ذلك يظهر في السنوات الأخيرة لكن بلرجة غير كافية لمواكبة عصر المعرفة والمساهمة فيه. للفجوة الرقمية لاى الباحثين التريويين آثار وأضرار بالغة على المعرفة التريويـة والتي يجب أن يتصف منتجوها بمواكبة التقدم العلمي والتكنولوجي وتوظيف معطيات العصر الرقمي في إنتاج المعرفة التريوية ونشرها وتوزيعها.

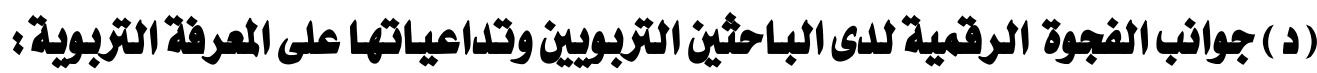


تتمثل الفجوة الرقمية في عدم القدرة على النفاذ إلى مصادر المعرفة واستيعابها وتوظيف هذه المعرفة لتوليد معرفـة جديدة في ضـوء توافر البنيـة التحتية لهذه الدورة المعرفية وتتمثل عناصر هذه الفجوة في النفاذ إلى مصادر المعرفة، و استيعاب هذه المعرفة ، الإبداع وتوليد

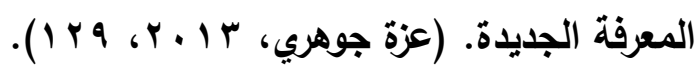
وللفجـوة الرقميـة تــاعياتها وآثارهـا السـلبية على النــواحي الثقافيـة والاقتصـادية والاجتماعيـة والسياسـية في المجتمـع ، وفي هذه الدراسـة ستقتصـر على تـداعياتها على المعرفة التريوية فقط، ويمكن القول أن مفهوم الفجوة الرقمية لاى الباحثين التريويين هو عدم القدرة على النفاذ والوصول إلى مصادر المعرفة التربويـة واستيعابها وتوظيفها لإنتاج معرفة تريويـة جديدة يتم نشرها على المستوى الداخلي والخارجي ومن ثم يمكن القول أن جوانب الفجوة الرقمية لاى الباحثين التربويين هي: 1 - النفاذ والوصول لمصادر المعرفة التريوية. r - استيعاب المعرفة التربوية. r- توظيف (تطبيق) المعرفة التريوية. ع - إنتاج وتوليد المعرفة التربوية. ه- نشر وتوزيع المعرفة التريوية. ولقد أصبح من البديهات والمسلمات في العصر الحالي ضرورة إلمام الباحثين التريويين بمهارات استخدام التكنولوجيا الحديثة و هو العنصر البشري ومدى امتلاكه للمعرفة والمهارة في استخدام التكنولوجيا الحديثة في مجال بحثه التربوي لأنه قـ يمتلك البنية التحتية وتوفر له جميع الإمكانات اللازمة للانضمام للعالم الرقمي ولكنه لا يوجد لايه الحد الأدني من المهارات اللازمة لاستخدام تلك التكنولوجيا الحديثة ومن تلك المهارات الأساسية اللازمة مهارة استخدام الحاسب الآلي من كتابة وقص ونستخ وطباعة واستخدام الإكسيل والورد وغيرها من برامج الحاسب الآلي ومهارات التعامل مع العالم الرقمي والصورة الرقمية للمعلومات والبيانات ، التي يحتاجها الباحث التريوي في إنجاز بحثه التريوي. 
تصور مقترح لسد الفجوة الرقمية لدى الباحثين التربويين كمدخل لتطوير المعرفة التربوية.

وفيما يلي توضيح لتلك الجوانب بشيء من التفصيل:

\section{ا - النفاذ والوصول لمسادر المعرفة التزبوية:}

حيث إنـه يجب على الباحث التربوي في العصر الحالي مواكبة العصر الرقمي بكل معطياته التي يمكن توظيفها لتطوير البحث التربوي والمعرفة التريويـة ، وعلى رأسـها تطوير

قدراته من معلومات ومهارات تساعده على الوصول والنفاذ إلى مصادر المعرفة التريوية. الوصول ( النفاذ ) أو الإتاحة الرقمي يقصد بها المشاركة الاكترونية الكاملة إتاحة الادوات و المصادر و الإنخراط للجميع في العصر الرقمي و توفيره للأفراد و يجب تقليص الفجوة بين أولئك الذين يستطيعون الوصول إلى أثنكال التكنولوجيا المختلفة و يستخدمونها وبين أولئك الذين لا تتوافر لايهم تلك الفرصة" ( تامر الملاح ، V V . Y، ه T).

وان عملية الوصول للمعلوملت و النفاذ إليها ليست سهلة بل "إن الوصول إلى المعلومات عبر شبكة الإنترنت هو أمر شديد الصعوية و يستهلك الكثير من الزمن الأمر الذي يتطلب وجود أدوات خاصة بالبحث عن الملفات والمعلومات لتصبح العملية أسهل و أسرع و هذه الأدوات المستخدمة عن المعلومات منها أدوات بحث نصية ، وأدوات بحث رسومية "( أبو

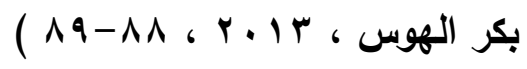

وعمليـة الوصـول للمعرفة هـي " عمليـة بنائيـة تطويريـة يقوم بها الباحث التربـوي بوضـع خطـة أو اسـتراتيجية جيدة للبحث عن المعلومــات كليـأ في بعض القواعد العالميـة المتخصصة على الويب وتعديلها وتحسينها للوصول إلى أفضل النتائج المطلويـة كمـاُ ونوعاُ في أسرع وقت ويأقل جهدمكن" وتحتوي هذه العملية على أربع مهارات هي: ( سماح أحمد

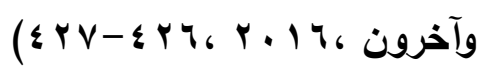
- يستخدم أدوات ربط مناسبة بين مصطلحات البحث .

- - يقوم بتنفيذ عملية البحث في إحدى الأدوات والمواقع المتخصصة على الويب . - - يعدل عملية البحث بطرق ملاعمة حسب نوع النتائج وعددها . 


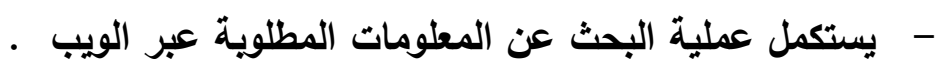

وحتى يتمكن الباحث من النفاذ والوصول إلى المعلومـات لابد من توفر الدعم والمساندة لله وتوفير الإمكانات اللازمة لذلك ، ومن متطلبات الوصول الرقمي " توفير التجهيزات للطلاب ، وجود البرامج لتزويد الوصول الرقمي ، وجود معلمين قادرين على تفعيل دور الوصول الرقمي

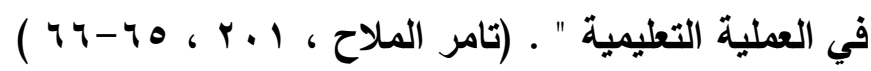
وتوصلت دراسة ماهر الضبع (ب ا • م م) إلى أن نفاذ ووصول الطلاب إلى المعلومـات

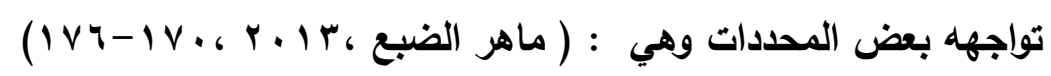

- المحددات الاجتماعيـة : ومنهاضـف دور الأسـرة في مسـاندة الطـلاب على اسـتخدام الإنترنت بل ومحاريته اعتقاداً من أولياء الأمور بأن الإنترنت له تأثير سلبي على أخلاقيات

الأبناء.

- المحددات الثقافية : ومنهاصعوية النفاد والوصول لقواعد البانات العالمية بلدون اشتراكات ، وعد إتقان اللغـة الإنجليزيـة الذي يحول دون الاستفادة من محتويـات الإنترنت ، وعدم

$$
\text { امتلاك مهارات التعامل مع الإنترنت للحصول على المعلومات . }
$$

- المحددات الاقتصادية :ومنا ارتفاع تكلفة الحصول على مهارات التعامل مع الإنترنت ،و ارتفاع تكلفة خدمة الإنترنت وارتفاع ثمن الأجهزة والبرامج •

وذلك يعني حتمية توفر البنية التحتية اللازمـة لـه للاندماج في العصر الرقمي من

إمكانـات مادية وتكنولوجية يجب أن توفرها لـه النظم التعليمية بالكليات والجامعات، ومن ثم يجب عليه امتلاك القدرة والمهارة على الوصول والنفاذ إلى مصادر المعرفة التريويـة المختلفة، ويعد الرجوع لعدة دراسـات منها دراسة (علي نصار، ؛ 1 • ب، 101 (1)، ودراسة (محمد حرب،

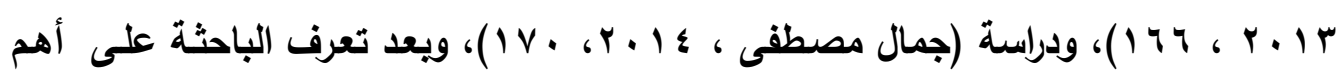
خصائص العصر الرقمي وأهم متطلباته فإنهـ يمكن القول أن من أهم الكفايات التي يجب أن يمتلكها الباحث التريوي للنفاذ والوصول إلى مصادر المعرفة التريوية هي ما يلي: - القدرة على الاستفادة من منجزات العصر الرقمي في البحث التريوي. 
تصور مقترح لسد الفجوة الرقمية لدى الباحثين التربويين كمدخل لتطوير المعرفة التربوية. - القدرة على استخدام الحاسب الآلي والإنترنت بمهارة. - القدرة على استخدام المكتبات الرقمية بكفاءة لتجويد البحث التربوي. - الوصول إلى المعلومات التريوية المتاحة ببنك المعرفة المصري. - القدرة على استخدام قواعد البيانات العالمية في العصول على المعرفة التريوية العالمية. - القدرة على الحصول على المعلومـات المتاحة على اتحاد المكتبات المصرية من رسـائل علمية ودوريات تريوية.

- القدرة على الحصول على دراسـات وأبحاث تربويـة في مجال تخصص الباحث التربوي من المواقع المتاحة على الإنترنت الأخرى مثل "جوجل سكولر" وغيرها من المواقع العلمية. - القدرة على استخدام شبكات التواصل الاجتماعي في الحصول على المعلومات التربوية المفيدة.

- القدرة على استخدام النقاش العلمي الإلكتروني في الحصول على المعرفة التربوية. - القدرة على المشاركة في حضور البرامج التدريبية في التربية عن طريق الإنترنت بمحركات البحث الإلكتروني. - القدرة على حضور المحاضرات الرقمية المتاحة على شبكات الإنترنت في مجال التخصص التربوي.

- المشاركة في حضور المؤتمرات العلمية التريوية الإكترونية. - القدرة على استخدام مهارات التواصل الإكتروني في الحصول على المعرفة التريوية بفعالية. - القدرة على الالتحاق ببرامج التعليم المفتوح والتعليم عن بعد للحصول على درجات علمية . r - استيعاب المعرفة التربوية ( تقثيم واستخلام المعرقة التزبوية )؛ يعد استيعاب المعرفة من أهم الكفايات التي يجب أن يتعلمها الباحث التريوي وذلك لأن استيعاب المعرفة في مجال البحث التربوي من أهم مقومـات البحث التربوي ويقصد بـه لهـ التكوين العلمي للباحثين وأعضاء هيئة التدريس في كليات التربية ، لأن أي مقومـات أخرى 
تصور مقترح لسد الفجوة الرقمية لدى الباحثين التربويين كمدخل لتطوير المعرفة التربوية.

في الباحث فهي قليلة الفائدة إذا لـ يتوفر في الباحث القدرة على تفعيلها والاستفادة منها".

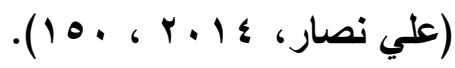

وإنه لا فائدة من المعلومات والمعارف التي يحصل عليها الباحث في المرحلة السابقة

إن لم يستطيع الباحث التربوي تنظيمها وفهمها واستخلاص المعرفة المفيدة لبحثه التربوي منها، خاصـة في العصر الرقمي الذي أصبحت فيها المعلومـات متـوافرة ويكثرة وهذه الكثرة المعلوماتيـة تعد مشكلة مثل قلـة توافرها، لذلك لابد أن يمتلك الباحث القدرات المختلفة التي

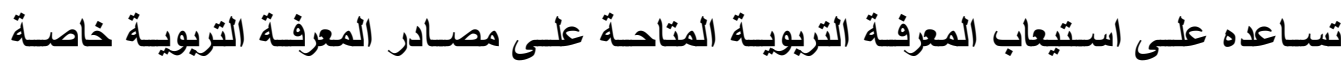
الإكترونية منها، وتلخص الباحثة أهم الكفايات اللازمـة للباحث التريوي لاستيعاب المعرفة التريوية في النقاط التالية: (على نصار، ؛ 1 . ب، . 10 - 101). - القدرة على استيعاب التطورات السريعة ، والمتلاحقة في المجال التربوي في العصر الرقمي مثل التعليم المفتوح والتعلم عن بعد والتعلم الافتراضسي والجامعات الافتراضية والقدرة على التعامل معها. - فهم الباحث للمفاهيم التريويـة الحديثة في المجال التربوي مثل عمال المعرفة ومجتمعات التعلم والمعرفـة التشـاركية ورأس المـال الفكري وغيرهـا مـن التطبيقـات المتجددة لتكنولوجيـا المعلومات والاتصالات في مجال التربية. - استيعاب المفـاهيم الدوليـة في البحث التريـوي مثل تدويل البحث والمشـروعات التريويـة الاولية والمختبرات التعاونية الدولية.

- القدرة على إقامة علاقات دولية للحصول على معرفة وتكوين معرفة دولية مشتركة معها. - القدرة على التعامل مع تطبيقات تكنولوجيا المعلومات في استيعاب وفهم المعرفة التريوية. - إتقان منهجيات البحث التربوي الحديثة لاستيعاب أحد المستجدات في البحث التريوي. - المشاركة في أنشطة تقاسم المعرفة التريوية مع الآخرين من المنتديات والملتقيات. وتضيف الباحثة إلى ما سبق بعض الكفايات التي يجب أن يمتلكها الباحث التربوي

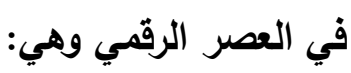




\section{تصور مقترح لسد الفجوة الرقمية لدى الباحثين التربويين كمدخل لتطوير المعرفة التربوية.}

- القدرة على تنظيم المعلومـات التي حصل عليها بشكل إلكترونـي وتكوين مكتبات إلكترونية خاصة به. - ماص.

- القدرة على توثيق المعلومـات التي يحصل عليها الباحث بثكل إلكتروني باستخدام برامج

إلكترونية مثل التوثيق الاكتروني مثل برنامج "الإند نوت" End - Note. - القدرة على ترجمة المعلومات الحاصل عليها خاصة المتاحة باللفة الإنجليزيـة ممـا يتطلب إتقان لتلك اللغة لكثرة المعلومات والمعارف المتاحة بها على شبكة الإنترنت. - القدرة على استخلاص المعارف والمعلومات التي تخص موضوع البحث التريوي بكفاعة نظرًا لوجود تضخم معرفي مريك للباحث التربوي. - امتلاك مهارات النقد والتفكير النقدي عند التعامل مـع المعلومـات المتاحة حتى يستخلص منها ما يفيد بحثه التريوي ويشكل علمي صحيح. - القدرة على امتلاك مهارات التفكير الموضوعي والبعد عن الذاتيـة والتحيز البحثي عند التعامل مع أراء الآخرين التريوية، بغض النظر عن خلقياتهم الجغرافية أو الثقافية. - القدرة على التحليل الدقيق للمعلومـات التريويـة المتاحة بثكل علمي يستطيع الباحث في النهاية الوصول ما يفيده في بحثه التريوي بشكل صحيح.

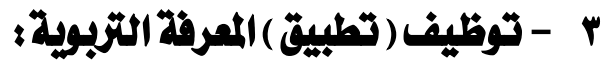

وإن الاندماج الرقمي للأفراد يجب أن يبدأ من السنوات الأولى للاراسـة وفي دراسـة والتي بحثت مدى الاندماج الرقمي للأطفال من سن (Judge , S. et al., 2006, 52 - 60) أربع سنوات وحتى الصف الثالث الابتدائي وتوصلت إلى أن المدارس قد تسهل الوصول إلى أجهزة الكمبيوتر بالمدرسة وتوفر ذلك للطلاب خاصـة في البيئات الفقيرة وتحقق المساواة في ذلكك ، لكنها لا تحقق المساواة في الاستخدام الذي يتوقف على عوامل اقتصادية واجتماعية

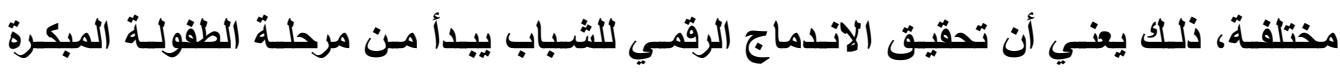
ويتطلب تحسين القدرات والمهارات اللازمة لاستخدام التكنولوجيا والتدريب عليها. 
ومن أهم الكفايـات التي يجب أن يتقنها الباحث التريوي هي القدرة على توظيف وتطبيق المعرفة التريويـة، حيث إن البحث التربوي يكون قليل القيمـة إذ لـ يتم الإفـادة مـن نتائجه في تطور المعرفة التريوية وإصلاح النظام التعليمي". (على نصار، ـ ا ـ ب ، ـ ه 1). ومن أهم الكفايات التي يجب أن يتقنها الباحث التريوي لتوظيف وتطبيق المعرفة في العصر الرقي من أجل إنتاج معرفة جديدة ترى الدراسة الحالية أنها ما يلي: - القدرة على الحكم على جودة البحث العلمي إلكترونيًا. - القدرة على استخدام الإنترنت في تطبيق الاستبانات بشكل إلكتروني. - القدرة على تحكيم أدوات البحث التربوي بشكل إلكتروني. - القدرة على تطبيق أدوات البحوث التربوية إلكترونيًا. - القدرة على استخدام برامج المعالجات الإحصائية مثل (SASS) ، (SPS) لمعالجة نتائج البحوث التربوية.

- القدرة على استخدام التكنولوجيا الحديثة في كتابة البحث التربوي وعمل الملقات المختلفة. - القدرة على الحصول على المساعدة من المسئولين عن المواقع الإكترونية البحثية. - الالتزام بأخلاقيـات البحث التريـوي عند استخدام وتوظيف المعرفـة التربويـة مثل الأمانــة العلمية وحقوق الملكية الفكرية. - القدرة على العمـل في فريق أثنـاء توظيف المعرفـة التريويـة خاصـة مـع المعلمين لإنتـاج معرفة جديدة تحل مشكلات التعليم. - القدرة على استخدام وسـائل التواصل الاجتمـاعي مثل تويتر والفيس بوك في التواصل مـع العلماء وتحكيم أدوات البحث. - الاستفادة من وسائل التواصل الاجتماعي في تطبيق أدوات البحث التربوي خاصـة العينات التي يصعب الوصول إليها. - الاستفادة من التكنولوجيا الحديثة في عمل المخططات وخاصة نظم محاكاة الواقع التريوي. ع - توليد وإتقاج المعرفة التزبوية في المصر الرقيمي? 
إن عملية إنتاج وتوليد المعرفة التريوية هي الغاية من إعداد البحث التريوي، خاصة التهنية

في عصر المعرفة والذي تعد فيه مساهمة المجتمع العربي والمصري ضعيفة في إنتاج المعرفة كما سبق توضيحه سابقًا في هذه الدراسة، وقلة الإنتاج الفكري العربي وضعف المحتوى الفكري العربي خاصة على شبكة الإنترنت، "ويعد البحث التريوي السبيل الوحيد المؤدي إلى اكتشاف الجديد من المعرفة التريوية والتوصل إلى القوانين والمفاهيم وإلنظريات العلمية الحاكمة لها والتي تمثل أسس قوية في تثكيل وتظوير منظومة المعرفة التريوية، وإنتاج معارف تريوية جديدة تسهم في تجديد المعارف التريوية القائمة".(على نصار، \&ـ أب، .$(104$

وإن عمليـة إنتاج وتوليد المعرفة التربويـة في العصر الرقمـي عمليـة ليست سـهلة

ويالتالي لابد أن يمتلك الباحث التريوي مجموعة من الكفايات اللازمـة لإنتاج المعرفة التريويـة في العصر الرقمي منها ما يلي: - القدرة على إنتاج معرفة تريوية جليدة تواكب التقدم العلمي والتكنولوجي الحادث عالميًا. - امتلاك الباحث التربوي لمهارات التفكير الإبداعي والابتكاري في إنتاج البحث التربوي. - القدرة على إنتاج معرفة تريوية تواكب التقدم العلمي والتكنولوجي الحادث في المجتمع وفي المؤسسات التعليمية. - قدرة الباحث التربوي على المحافظة على عنصر الأصسالة في إنتاج البحث التريوي في العصر الرقمي. - قرة الباحث وتحكمه في أفكاره في البحث التربوي بحيث لا ينبهز بالأفكار الحديثة البراقة التي لا تصلح لواقع المجتمع المصري. - استخدام الباحث لمنـاهج البحث التربـوي الحديثة والمعاصـرة في إنتـاج البحوث التريويـة والمستخدمة في الأبحاث التريوية العالمية. - اسـتخدام الباحث لمـاخل استشـراف المسـتقبل لإنتـاج معرفـة تريويـة تعمـل على تطوير المستقبل التريوي وتتناسب معه. 


\section{تصور مقترح لسد الفجوة الرقمية لدى الباحثين التربويين كمدخل لتطوير المعرفة التربوية.}

- قيام الباحث التربوي بإنتاج معرفـة تربويـة تقوم على تكامل العلوم الأساسية والتطبيقية لتطوير المعرفة التريوية. - اختيار الباحث في البحث التربوي لقضايا تريويـة معاصرة تساير الاتجاهات المعاصرة في البحث التربوي.

- تحقق التكامل بين التخصصات التريوية بإنتاج بحوث تربوية بينية تحقق تكامل المعرفة التريوية.

- اختيار الباحث التريوي لموضوعات معاصرة يقوم بدراستها تتناسب مـع احتياجات المجتمع المعاصرة وتستفيذ من معطيات العصر في حلها. - استخدام الباحث للمعايير والمؤشرات الدولية في دراسته للقضايا التريويـة الوطنية من أجل تطوير المعرفة التريوية في المجتمع التريوي. - إتقان الباحث لاستخدام المداخل الحديثة لقياس أداء النظم التعليمية والمؤسسـات التربوية من أجل تطويرها حتى تواكب العالم الخارجي. - الاستفادة من التكنولوجيا الحديثة في التواصل لإنتاج بحوث تربويـة مشتركة مـع جهات دولية لتطوير المعرفة التريوية في المجتمع. - قدرة الباحث التريـوي على تلخـيص نتـائج أبحاثـه بشـكل علمـي واســتخدام المخططـات والرسومات والجداول وتمثيلها بشكل إلكتروني يسهل ويسرع من فهمها.

\section{0}

إن نشر وتوزيع المعرفة التريوية هو الطريق إلي تقاسم المعرفة التريوية مـع الآخرين بالداخل أو بالمجتمع الدولي وهي الطريق لانتشـار الفكر التربوي والمعرفة التريويـة وتداولها محليَا وعالميًا ، "ويمثـل النشـر العلمـي أهـم الأنشـطة الأكاديميـة لأعضــاء هيئسة التـدريس بالجامعات ، حتى أن الأمر يصل في العديد من الجامعات والمؤسسـات البحثية في العالم إلى اعتبار النشر العلمي أحد أهم المعايير التي تحدد إمكانية بقاء الأكاديميين في مواقعهم أو 
الاستفناء عنهم لتظهر المقولة المشهورة في الجامعات المتقدمة النشر أو الفصل"، وكذلك الأمر عند ترقيات أعضاء هيئة التدريس لوظيفة أعلى. (جمال مصطقى، ب ا ـ ب ، 1 ا I). وفي العصر الرقمي تزداد أهمية النشر الإكتروني بصفة خاصة عبر الإنترنت وقواعد البيانات العالمية والمكتبات الرقمية ، حيث إنه لابد من نشر الإنتاج العلمي التربوي من أجل تقاسمه مع الآخرين وتطوير المعرفة التريوية. وفي المجتمع المصري أصبحت عملية النشر الإلكتروني هامة للغاية حيث أصبحت غالبية الدوريات التريوية تسعي للحصول على النشر الدولي والسعي إلى إدراجها ضمن قواعد البيانات العالمية حتى تحصل على معامل تأثير عالي وترفع مكانتها العلمية عربيًا ومحليًا وتتيح محتوا ها بثكل إلكتروني حتى وإن كانت تصدر بشكل ورقي فهي تتاح ورقيًا وإلكترونيًا. ويجب على الباحث التربـوي أن يتمتـع بمجموعـة مـن الكفايـات اللازمـة لـه لنشـر

وتوزيع المعرفة التريوية في العصر الرقي منها ما يلي: - القدرة على عمل مدونات شخصية لنشر إنتاجه العلمي بها. - القدرة على عمل مواقع إلكترونية لنشر إنتاجه العلمي بها مثل المواقع الرسمية للجامعات وجوجل سكولر وغيرها من المواقع العلمية الأخرى. - القدرة على التواصل مع الدوريات التربوية بشكل إلكتروني لنشر إنتاجه العلمي بها. - نشر إنتاجه العلمي بالتجمعات العلمية البحثية على الإنترنت. - القدرة على التواصل مع دور النشر بشكل إلكتروني لنشر إنتاجه العلمي بها. - القدرة على نشر ملخصات أبحاثه في المواقع العلمية الأكاديمية للاستفادة منها. - استخدام شبكات التواصل الاجتماعي لتعريف الآخرين بإنتاجه العلمي وكيفية الوصول إليه. - قدرة الباحث التريوي على نشر أبحاث التربوية في دور نشر ومجلات تريوية دولية للإسراع من انتشارها عالميًا. - معرفة الباحث التريوي لمعايير وشروط النشر الدولي والالتزام بها لتسهيل نشر إنتاجه التربوي دوليًا. 


\section{تصور مقترح لسد الفجوة الرقمية لدى الباحثين التربويين كمدخل لتطوير المعرفة التربوية.}

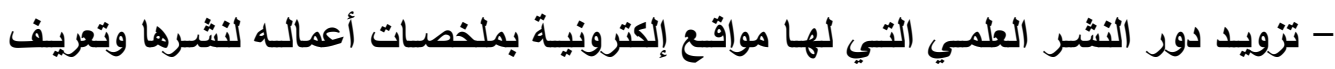

الآخرين بها.

- قرة الباحث التربوي على كتابـة إنتاجـه العلمي بلغات أجنبية مثل الإنجليزيـة ويشكل جيد حتى يتم نشرها بشكل دولي وتتنشر بشكل أسرع عالميًا. - استخدام الباحث التربوي التكنولوجيا الحديثة في التعرف على الدوريات التريوية المرموقة وتصنيفاتها ومعامل تأثير كل منها، وترتيبها من حيث جودتها ومدى انتشارها عالميًا. تلك كانت أهم الكفايات التي يجب أن يتقنها ويلم بها الباحث التريوي في العصر الرقمي وإنه في حالة الإلمام بها فإنه لا توجد أي فجوة رقمية لاى الباحث التربوي، ولكن في حالة عدم الإلمام بها أو ضعفها فإنها توجد بالتأكيد فجوة رقمية لدى الباحثين التريويين ومن ثَّم تؤدي الفجوة الرقمية إلى فجوة في المعرفة التربوية ولكن في حالة سد تلك الفجوة الرقمية فإن ذلك سيؤدي إلى تظوير المعرفة التريوية.

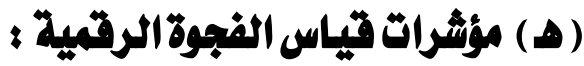

توجد أراء متباينة حول قياس الفجوة الرقمية وهذا التباين في الأراء يضيق ويتسع حسب مفهوم الفجوة الرقمية الذي يتراوح مـا بين المفهوم الضيق لها والمفهوم الثـامل وقد سبق توضيح ذلك في مفهوم الفجوة الرقمية. فهناك من يقتصر تعريفه للفجوة الرقمية على الوصول الرقمي ومن ثم يرى أن قياس الفجوة الرقمية ينحصر في قياس مؤثر الوصول وهو المنهجية المعتمدة للاتحاد الدولي للاتصالات في قياس الفجوة الرقمية ويتم قياس مؤثر الوصول الرقمي كما يلي: (إخلاص

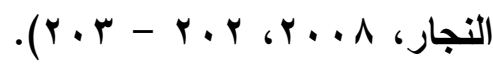
- مؤثر البنية التحتية: وتتمثل في خطوط الهاتف الثابت والمحمول. r - مؤثر الاستطاعة المادية: للاخول على الإنترنت. r- مؤثر المعرفة: ويتمثل في نسبة البالغين الملمين بالقراءة والكتابة ونسبة القيد بالتعليم الثانوي والجامعي. 
تصور مقترح لسد الفجوة الرقمية لدى الباحثين التربويين كمدخل لتطوير المعرفة التربوية.

ع - مؤثـر الجـودة: ويتمثل في نصـيب الفـرد مـن سـعة الاتصـال الدوليـة بالإنترنـت وعدد

المشتركين بالإنترنت.

ه- مؤشر الاستخدام: ويعبر عنه بعدد مستخدمي شبكة الإنترنت لكل . . 1 من السكان. وهناك ينظر إلى الفجوة الرقمية بمنظورأوسـع ويرى أن قياس الفجوة الرقمية ومدى

تجسيرها يتم من خلال ثلاثة عناصر هي: (حنان بيزان ، ه 1 ـ ب، ب I ).

1 - النفاذ إلى تكنولوجيا المعلومات والاتصالات ( البنية والنفاذ).

r - استخدام تكنولوجيا المعلومات والاتصالات (الاستخدام وكثافته).

r- مهارات تكنولوجيا المعلومات والاتصالات(المهارات أو القدرة اللازمة لاستخدام

(التكنولوجيا).

وترى دراسة (Barzilai - Nahon, K. , 2006, 273) أن مؤشرات قياس الفجوة

الرقمية وتحديدها تتلخص في مدى وجود قيود أو دعم اجتمـاعي وحكومي، القدرة على تحمل التكاليف ، القدرة على الاستخدام، امتلاك البنية التحتية اللازمـة، وإمكانية الوصول الرقمي، العوامل الاجتماعيـة وإلديموغرافيـة علمـا بأن تلكـ المؤشترات تثقاعل معًا وتؤثثر على بعضـها البعض ولابد من النظر إلبها نظرة متكاملة.

وترى دراسة (Fuchs, C. , Horak, E. , 2008, 101) أن الفجوة الرقمية ثمانية

جوانب لابد من قياسها وهي:

1. الوصول المادي (الوصول إلى أجهزة تكنولوجيا المعلومات والاتصالات).

r. النواحي المالية والوصول إلى الخدمات (تكلفة خدمات تكنولوجيا المعلومـات والاتصالات بالنسبة إلى الاخل السنوي). r. النفاذ المعرفي (مهارات تكنولوجيا المعلومات والاتصالات). ع. الوصول إلى التصميم (قابلية الاستخدام). ه. الوصول إلى المحتوى (توافر التطبيقات والمعلومات ذات الصلة عبر الإنترنت). 4. الوصول إلى الإنتاج ( القدرة على الوصول إلى إنتاج المحتوى الخاص به ) . 


\section{تصور مقترح لسد الفجوة الرقمية لدى الباحثين التربويين كمدخل لتطوير المعرفة التربوية.}

V. الوصول المؤسسي (توافر المؤسسات التي تُمكن من الوصول).

^. سياسات الوصول (الوصول إلى المؤسسات الحاكمة حيث يتم كتابة القواعد المنظمة

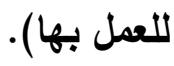

ويلاحظ أن هذا الرأي جامع لكل مؤثشرات قياس الفجوة وأكثر شـولاً من غيره من

الأراء الأخرى.

أما أصحاب المفهوم الشامل للفجوة الرقمية يرون أنه توجد مقاييس أشمل وأكثر وقد

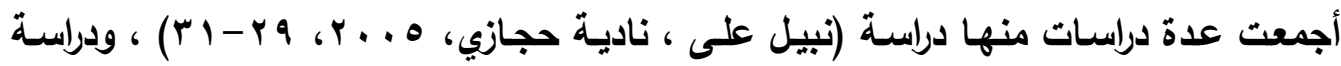

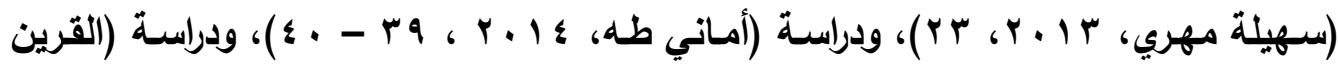

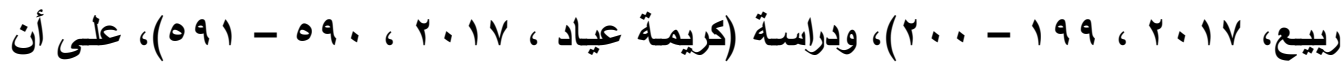
مؤشرات قياس الفجوة الرقمية هي ما يلي: 1. مؤثثـر الكثافـة الاتصـالية : يقـاس بعدد الهواتـف الثابتـة والمحمولـة لكل . . 1 فـرد في

المجتمع.

r. مؤشر التقدم التكنولوجي: ويقاس بعدد الحاسبات وعدد مستخدمي الإنترنت وحيازة

الأجهزة الإلكترونية.

r. مؤثر الإنجاز التكنولوجي: ويقاس بعدد براعات الاختراع، وعدد تراخيص استخدام التكنولوجيا وحجم صادرات منتجات التكنولوجيا، بالإضافة لمتوسط سنوات التحصيل

الإراسي.

؛. ـ مؤثرات الأكاء المعلوماتي: ويقاس بعدد حلقات النقاش عبر الإنترنت، والأورلق العلمية التي تثترك فيها أكثر من مؤلف وعدد اللقاءات العلمية ونطاق الموضوعات. ه. مؤشر جاهزيـة الشبكات: ويقاس بمستوى البنية التحتية لتكنولوجيا المعلومـات اللازمـة لإتاحة القرصة للكفاءات لاستخدامها.

7 . . مؤثر استخدام وسائل الإعلام: ويقاس بدلالـة عدد وسـائل الإعلام الجماهيري من أجهزة الراديو والتلفزيونات والصحف والمجلات وساعات المشاهدة والاستماع والقراءة. 
V. الرقم القياسي للنفاذ: ويقوم على أسـاس عدة عوامل تؤثر على قدرة بلد على النفاذ إلى تهئ تكنولوجيـا المعلومـات والاتصـالات وهـي البنيـة التحتيـة والاسـنطاعة الماديـة والمعرفيـة والتوعية من حيث سعة نطاق تبادل المعلومات. ^. مؤشر مدى الانخراط في حركة العولمة: وهو مؤثر غير مباشر لقياس الفجوة الرقمية ويقاس عادة بمدى الاندماج في العالمية. ويالتالي من مؤشرات القياس للفجوة الرقمية كـلا من مؤثشرات النفـاذ بوزن مقداره

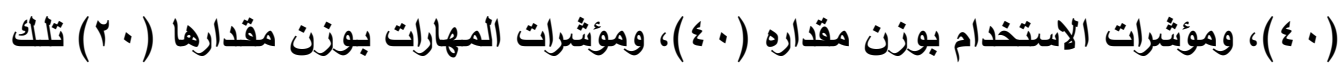
كانت مؤثرات قياس الفجوة الرقمية في الدول والمجتمعات المختلفة وهي التي تحدد مدى ردم وتجسير الفجوة الرقمية بها. أما بالنسبة لمؤشرات قياس الفجوة الرقمية لدى الأفراد فيمكن القول أنها تشتمل على مدى

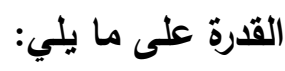
• النفاذ والوصول لمصادر المعرفة.

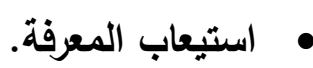
• توظيف (تطبيق) المعرفة. • توليد المعرفة ونشرها وتوزيعها. وذلك تبعًا لأبعاد الفجوة الرقمية ووفقًا لدورة اكتساب المعرفة الموضحة سابقًا.

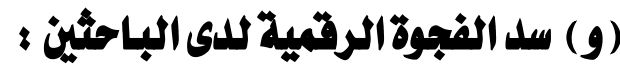

ولقد أوضحت دراسة (Halili, S. H. \& Sulaiman , H. 2018, 1 - 5) والتي أُجريت بماليزيا أن هناك جهود بماليزيا لسد الفجوة الرقمية لدى الطلاب والمواطنين في كل من الريف وإلحضر وذلك لإدخال تكنولوجيا المعلومـات والاتصـالات في المشروعات التنمويـة بكل قطاعات التعليم والصحة والاقتصاد من أجل تحقيق التنمية المستدامة وخطة . r • r م في 
وكنلك اتفقت مع ذلك دراسة (Fuchs, C. \& Horak, E., 2008, 99 - 116)

والتي أوضحت أنه لكي يتم تحقيق التنمية المستدامة في المجتمع وخاصة في (غانا وجنوب أفريقيا) لابد من سد الفجوة الرقمية لاى المتعلمين والمواطنين واستخدام تكنولوجيا المعلومات

والاتصالات لتحقيق التنمية المستدامة بها. وتثير دراسة (Rodrigo, M. M. T. , 2005, 54 - 55) إلى أن التقديرات توضح أن تكنولوجيا المطومات والاتصالات من محفزات التنمية في المجتمع وأنها سـاهت

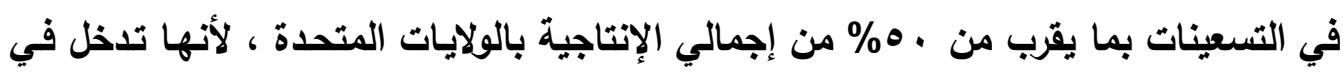

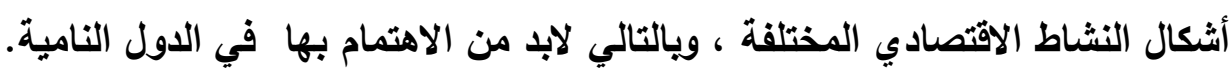

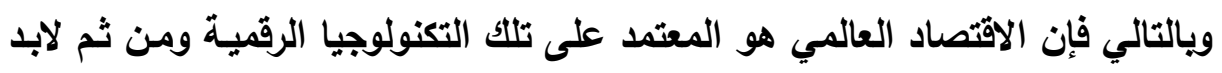
من العمل على سد الفجوات الرقمية في مصر خاصدة لاى المتعلمين والمعلمين والباحثين

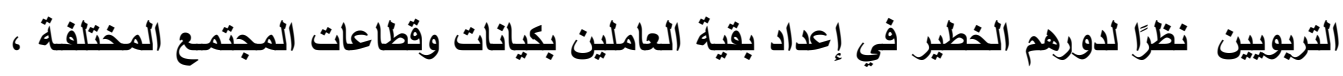

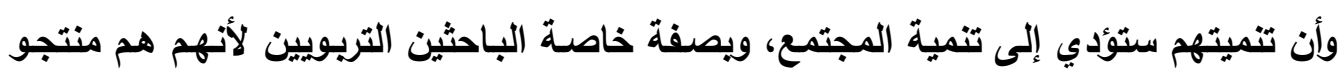

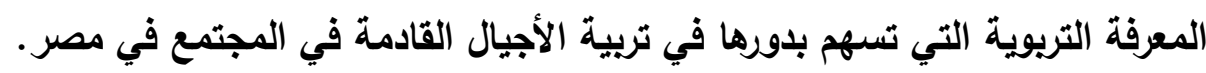

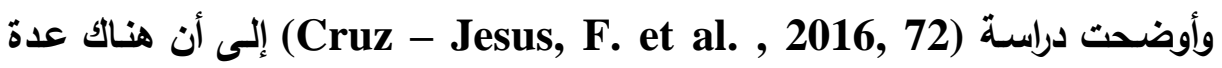
منظمات دولية مثل وزارة التجارة الأمريكية والأمم المتحدة قد أوضحت أن سد الفجوة الرقمية للدى الأفراد يعمل على تمكين الأفراد والمجتمعـات مـن إنثـاء المعلومـات والوصسول إليها واستخدامها ومشاركتها المعرفة ويالتالي تتمكن الأفراد والمجتمعات من تحسين نوعية حياتها

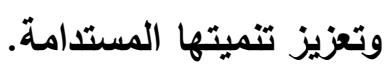
وتضيف تلك الاراسة من أن هناك علاقة وثيقة بين الفجوة الرقية ومستوى التعليم

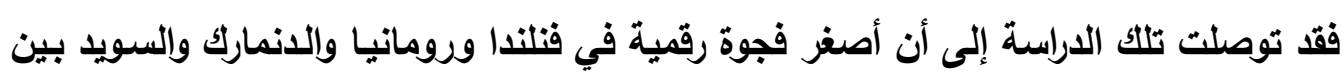

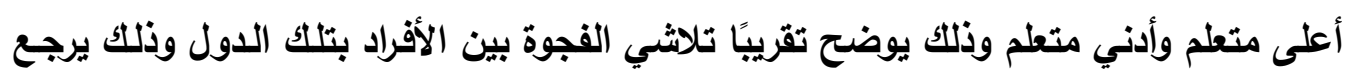

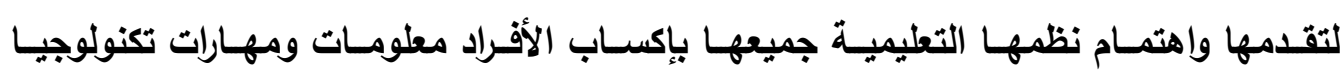




\section{تصور مقترح لسد الفجوة الرقمية لدى الباحثين التربويين كمدخل لتطوير المعرفة التربوية.}

(Cruz - Jesus, F. et. al., المطومات والاتصالات بشكل جيد داخل مؤسساتها التعليمية) 2016, 74 - 75)

ترى دراسة (Fuchs, C. \& Horak, E. , 2008, 114) أنه لكي يتم سد الفجوة الرقميـة في العالم لابـد من استراتيجية متكاملـة تجمع بين إعـادة التوزيـع العـالمي للثروة والتعليم والصحة من خلال برامج محو الأمية الرقمية وإتاحة الوصول المجاني إلى أجهزة الكمبيوتر والإنترنت خاصة بدول العالم الثالث. ترى دراسة (Mcphail, T. L. , 2009, 139 - 140) أن أهم معوقات وحواجز سد بد الفجوة الرقيـة هي أريع فئـات هي: الاقتصـادية والماليـة والتتظيمية والمؤسسية والبشرية

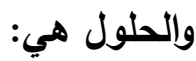

- تحسين الاقتصاد والنواحي والإمكانات المالية اللازمـة لها لتوفير البنية التحتية اللازمـة لتملك تلكك التكنولوجيا في المجتمع. - سَنَن سياسـات وتثـريعات وطنيـة واضـحة لـاعم اكتســاب التكنولوجيـا وتطويرهـا وتطوير المعارف والمهارات المحلية في ذلك. - إيجاد طرق لترريب الموارد البشرية وتطوير المهارات في استخام وإدارة المشروعات

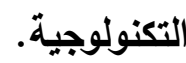
- تحسين البنية التحتية من اتصالات سلكية ولا سلكية للحصول على المزيد من الاستخام. وترى دراسة (Rao, S. S. , 2005, 261 - 275) أن أول خطوة في حل وسد الفجوة الرقمية في الهند هو تبني السياسات الحكومية الهندية لذلك واعتبرته مشروعاً قومياً سيحول الهند

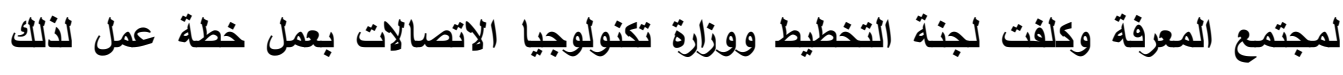
واعتبار تكنولوجيا المعلومات والاتصالات فرصة جديدة لتحسين الوضع الاقتصادي في كل قطاعات المجتمع، وأن ذلك سيحل المثكلات القديمة في مجالات التعليم والصحة والتنمية 
تصور مقترح لسد الفجوة الرقمية لدى الباحثين التربويين كمدخل لتطوير المعرفة التربوية.

الريفية والتخفيف من حدة الفقرة، والحكم الرشيد ، والتمكين والإدارة التشاركية والديمقراطية الثعبية.

ولكي يتم سد الفجوة الرقمية في مصر كما أوضحته دراسة أجريت لتشريح وتحليل

الفجوة الرقمية في مصر لابد من توفر عدة موارد لذلك وهي: WWarschauer, M. , 2005)

ا - الموارد المادية وتثمل الوصول إلى أجهزة الكمبيوتر والاتصالات السلكية واللاسلكية. r - الموارد الرقمية وتشير إلى المواد الرقمية التي يمكن توفيرها عبر الإنترنت. r- المـوارد البشـرية وتـدور حول إعداد القوى البشـرية التي تستطيع القيـام بالتعامـل مـع التكنولوجيا الحديثة وتثمل محو الأمية والتعليم وإستخدام الكمبيوتر والاتصال بالإنترنت. ع - الموارد الاجتماعية وهي تثير إلى المجتمع والهياكل المؤسسية والمجتمعيـة التي تدعم الوصول إلى تكنولوجيا المعلومات والاتصالات. ولابد من توفر كل العناصر الأربعة السـابقة وتكاتفها حتى تسد الفجوة الرقمية في العصر الرقمي لأن عملية سد الفجوة الرقمية لابد منها من أجل حدوث التنمية الاقتصادية والاجتماعية والمعرفيـة والسياسية، وتطوير المعرفة على رأس هذه الفوائد لأنه يترتب عليه تقدم بقية جوانب المجتمع. ويمكن القول أنها لكي يتم سد جميع جوانب الفجوة الرقمية لدى الباحثين لابد من توفير البنية التحتية وتحسن أوضاع الباحثين التريويين وتطوير نظم إعدادهم حتى تتفق مع معطيات وتطورات العصر الرقمي المتلاحقة. وفي الجزء التالي من الاراسـة سوف يتم التعرف على واقع جوانب الفجوة الرقمية لاى الباحثين التريويين ، وكذلك التعرف على أهم أسبابها لديهم من أجل العمل على سدها والقضاء عليها. 
الدراسة الميدانية ؛

\section{إجراعات الدراسة الميلدانية: \\ أولاء أهداف الدراسة الميدانية:}

إستهفت الاراسة الميدانية التعرف على:-

1- واقع الفجوة الرقمية لاى الباحثين التريويين بمرحلة الماجستير و مرحلة الدكتوراة. r- هل هناك فروق ذات دلالة إحصائية بين استجابات طلاب مرحلة الماجستير و ولئين استجابات طلاب مرحلة الدكتوراة حول واقع الفجوة الرقمية لاى الباحثين التريويين أم

У

r- هل هناك فروق ذات دلالة إحصائية حول واقع الفجوة الرقمية بين الباحثين التربويين والباحثات ترجع للجنس أم لا.

\section{ثانياء أدوات الدراسة الميلانية:}

لتحقيق أهداف الدراسة تم استخدام الأدوات التالية:

1- استبانة من إعداد الباحثة للتعرف على واقع واقع الفجوة الرقمية لاى الباحثين التريويين بمرحلة الماجستير و مرحلة الاكتوراة بكليات التربية.

r - المقابلة الثخصية مع عدد من الباحثين والباحثات للعرف على أسباب الفجوة الرقمية

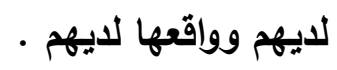

وقد تم إعداد الاستبانة باتباع خطوات وقواعد بناء الاستبانات من حيث شكل العبارات وطولها وقواعد كتابتها وتم ذلك وفقاً للخطوات التالية:

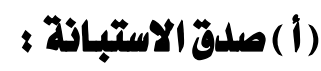

وقد استخدت الباحثة صدق المحتوى للتأكد من أن العبارات تنتمي إلى المحاور

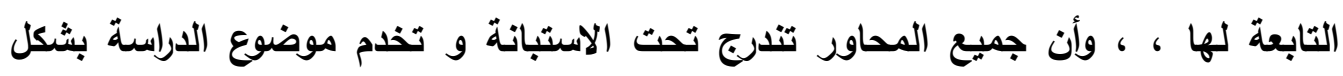


واضح وكبير، وللتأكد من صدق محتوى الاستبانة فقد تم عرضهاعلى مجموعة من السادة المحكمين من الأساتذة المتخصصين في أصول التربية للتأكد من صحة البنود ومدى إنتمائها للمحاور التابعة لها وأنها تغطي جوانب موضوع الدراسة المراد دراسته وتمثله تمثيلاً صادقًا . ولقد كاتت الاستبانة في البداية تحتوى على محور سادس عن أسباب الفجوة الرقمية لاى الباحثين وكان عدد عباراتها ( . . 1) عبارة لكن أجمع السادة المحكمن على حذف هذا المحور والاكتفاء بالمحاور الخمسة التي تقيس الفجوة الرقمية لاى الباحثين التريويين( أنظر ملحق رقم (1) الصورة الأولية للاستبانة ، وتم إجراء بقية التعديلات المطلوية في بعض المحاور وفقاً لأراء السادة المحكمين من تعديل وحذف وإضافة حتى وصلتا إلى صورتهما النهائية.

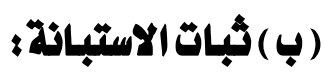

وقد تم حساب معامل ثبات هذه الاستبانة عن طريق استخدام برنامج SPSS وحساب معامل (ألفا كرونباخ) لحساب ثابت الاستبانة وقد وجد أن معامل ثبات الاستبانة هو (1 9, •) ، وهو معامل ثبات مرتفع وملائم للاستبانة ويذلك تكون صالحة للتطبيق الميداني ،

\section{( ) المورة النهائية لالستبانة:}

بعد إجراء التعديلات على الاستبانة جاءت في صورتها النهائية متكونة من سبعون ، عبارة وتلك العبارات هي مؤثرات لقياس الفجوة الرقمية لدى الباحثين التريويين (V. ) وهذه العبارات مقسمة إلى خمسة محاور وهي ( أنظر ملحق رقم (ץ): - المحور الأول: واقع النفاذ و الوصول إلى مصادر المعرفة التريوية و يتكون من

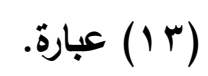

- المحور الثاني: واقع استيعاب ( تنظيم و استخلاص)(المعرفة التريوية و يتكون من

$$
\text { ( - ( - n) }
$$




\section{تصور مقترح لسد الفجوة الرقمية لدى الباحثين التربويين كمدخل لتطوير المعرفة التربوية.}

- المحور الثالث: واقع توظيف وتطبيق المعرفة التريوية في العصر الرقمي و يتكون

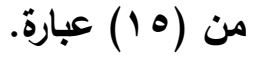

- المحور الرابع: واقع توليد و إنتاج المعرفة التريوية في العصر الرقمي و يتكون من

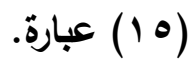

- المحور الخامس: نشر و توزيع المعرفة التريوية في العصر الرقي و يتكون من

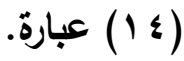

\section{ثالثاء مينة الداراسلة وأسلوب اختياروهاء}

تم اختيار عينة من طلاب مرحلة الماجستير ومرحلة الدكتوراة لتطبيق الاستبانة عليهم بالطريقة العشوائية الطبقية، وهي الطريقة التي يتم اختيار العينة بها في حالة وجود صفات متنوعة ومختلفة بين عناصر المجتمع الأصلي ، "حيث يقوم الباحث بتقسيم المجتمع الأصلي إلى طبقات متجانسة ثم يقوم بعد ذلك باختيار عينة بشكل عشوائي من كل طبقة بحيث تتناسب العينة مع حجم تلك.

ويلغ عدد أفراد العينة الكلية التي تم التطبيق عليها(·PV) باحثاً، مع العلم بأن إجمالي عدد الباحثين بكلية التربية بجامعة سوهاج (ه ـ ب) باحثاً، ويلغ عدد الاستبانات الصحيحة منها التي خضعت للمعالجة الإحصائية (Y Y T استبانة والجدول التالي يصف العينة:

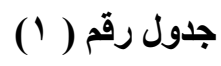

\begin{tabular}{|c|c|c|c|c|}
\hline النسبة المئوية من العينة \% & الإجمالي & إناث & ذكور & المرحلة الدراسينة \\
\hline$\% 70.9$ & $1 \leq V$ & $\Lambda r$ & $7 \varepsilon$ & مرحلة الماجستير \\
\hline$\% r \varepsilon .1$ & Vq & rq & $r v$ & مرحلة الدكتوراة \\
\hline$\% 1 \ldots$ & TrY & TYY & 1.1 & الإجمالي \\
\hline
\end{tabular}

وصف عينة الدراسة الميدانية وفقاً لمرحلة الدراسة ووفقا للنوع 


\section{تصور مقترح لسد الفجوة الرقمية لدى الباحثين التربويين كمدخل لتطوير المعرفة التربوية. رابعاً ؛ تطبيق أداةالدراسة اليدانية:}

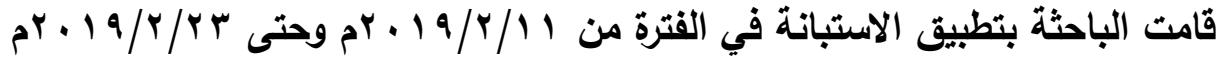
واستظلت الباحثة حضور الباحثين والباحثات لحلقات السمينار العلمي بالأقسام المختلفة بكلية التربية بجامعة سوهاج للتطبيق عليهز ، كما تم تطبيق مجموعة من الاستبانات عبر شبكة التواصل الاجتماعي (الفيس بوك) وتم التطبيق على مجموعة باحثين تريويين أغلبهم بمرحلة الاكتوراة ببعض كليات التربية الأخرى ل

\section{خامساً ؛ المعالجة الإحصائية لاستجابات العينة على أدوات الدراسة اليدانية:} بعد التطبيق المياني تمت المعالجة الإحصائية لنتائج الاستبانة كما يلي: 1. تم حساب نسبة متوسط الاستجابة لنتائج التطبيق الميداني للاستبانة وحساب حدود الثقة

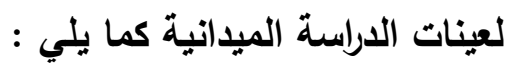

\section{أولاء حساب نسبة متوسط الاستجابة ولعسابها تقت المعالجة التالية:}

1 - حساب تكرارات استجابات أفراد العينة تحت درجات التحقق الثلاثة (كبيرة -متوسطة ضعيفة).

ץ- أعطيت الأوزان الرقمية لكل درجة تحقق كما يلي:الكبيرة (ץ)، والمتوسطة(ץ) ، والضعيفة

ץ- تم ضرب التكرارات تحت كل درجة موافقة في الوزن الرقمي المناظر له. ع - جمع حاصل الضرب السابق لكل بند على حدة والحصول على الارجة الكلية للبند. هـ - الحصول على نسبة متوسط الاستجابة وذلك بقسمة الارجة الكلية للبند على عدد أفراد

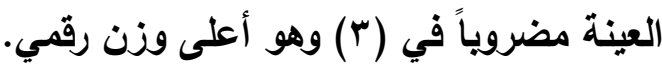




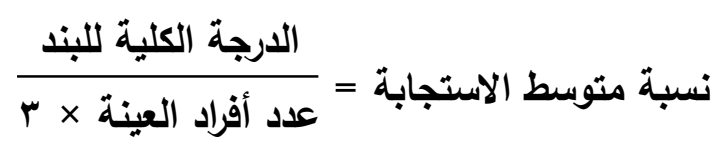

\section{ثانيا: حساب حدود الثقد للكابلة كما يليج:}

الخطأ المعياري =

$$
\text { حيث: أ = نسبة متوسط شدة الموافقة على البند = }
$$

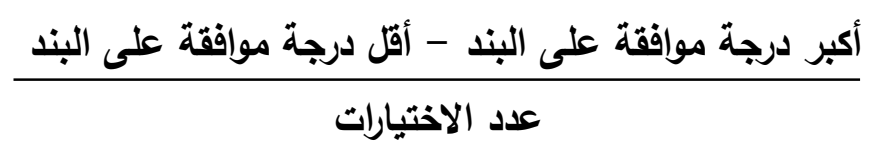

$$
\begin{aligned}
& .7 V=\frac{r}{r}=\frac{1-r}{r}= \\
& \text { بr }=. .7 V-1=\quad 1=1=10 \\
& \text { ن = عدد أفراد العينة. }
\end{aligned}
$$

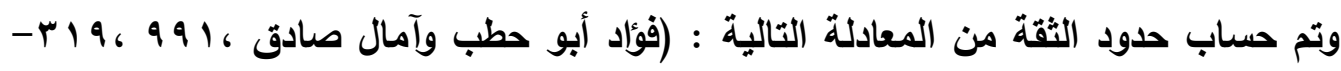
(rrt

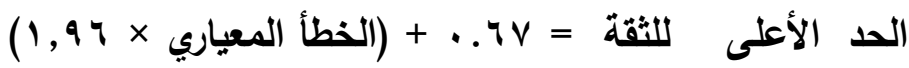

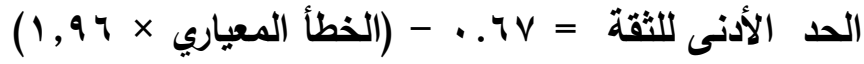

ويحساب حدود الثقة لعينة البحث الكلية والبالغ عددها (Y Y استبانة صحيحة كانت

$$
\cdot(\cdot .1 \cdot \cdots V)
$$

وإذا كاتت نسبة متوسط الاستجابة على العبارة تساوي الحد الأعلى أو أكبر منه كانت النتيجة أن العبارة تتحقق بدرجة كبيرة ، وإذا كاتت نسبة متوسط الاستجابة تساوي الحد 
تصور مقترح لسد الفجوة الرقمية لدى الباحثين التربويين كمدخل لتطوير المعرفة التربوية. الأدنى أو أقل منه كانت النتيجة أن العبارة تتحقق بلرجة ضعيفة وإذا انحصرت بين القيمتين كانت النتيجة أن العبارة تتحقق بلرجة متوسطة .

\section{ثانيا ؛ حساب دلاثلة الفروق بين استجابات المينات الفرمية}

وقد استخدم اختبار (T-Test) لمعرفة هل هناك فروق ذات دلالة إحصائية بين استجابات الباحثين بمرحلتي الماجستير والدكتوراة وكذلك لحساب دلالة الفروق بين استجابات الاناث والذكور حول واقع الفجوة الرقمية لديهم أم لا وذلك عن طريث استخدام برنامج

.(SPSS)

نتائج الدراسة الميدانية:

أولا : نتائج استبانة التعرف على واقع الفجوة الرقمية للدي الباحثين التربويين

وتفنسيرهـا

المحور الأول : النفاذ والوصول إلى مصادر المعرفة التربوية

بعد إجراء المعالجة الإحصائية لاستجابات عينة الدراسة على عبارات الاستبانة جاءت

جدول رقم (r) و (r)

النتائج كما بالجدول التالي :

نسبة متوسط استجابة العينة الكلية حول واقع النفاذ والوصول إلى مصادر المعرفة التربوية

\begin{tabular}{|c|c|c|c|c|}
\hline العبارة & التحقق & منتوسبة & 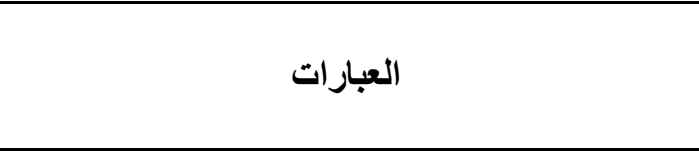 & رقبارة \\
\hline r & كبيرة & $\because \wedge$ & القرة على الاستفادة من منجزات التجات العصر الرقمي في & 1 \\
\hline 1 & كبيرة &.$\wedge r$ & 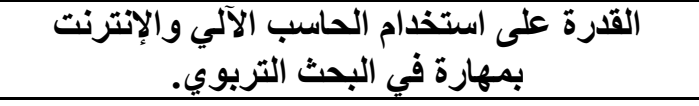 & r \\
\hline V & متوسط &. .74 & 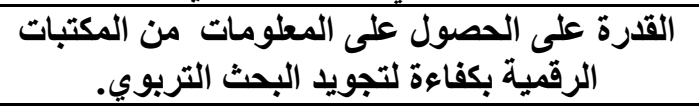 & $r$ \\
\hline$r$ & كبيرة &. .17 & 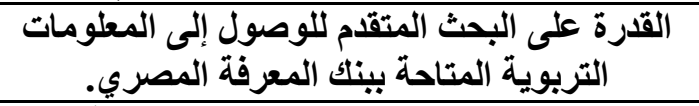 & $\varepsilon$ \\
\hline 9 & ضعيفة & .09 & 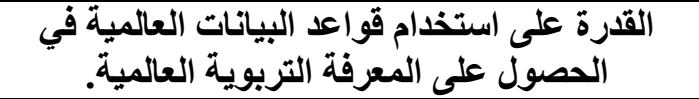 & 0 \\
\hline$\varepsilon$ & كبيرة &.. $\mathrm{V}$ & القدرة على الحصول على المعلومات المتاحة على & 7 \\
\hline
\end{tabular}


تصور مقترح لسد الفجوة الرقمية لدى الباحثين التربويين كمدخل لنطوير المعرفة التربوية.

\begin{tabular}{|c|c|c|c|c|}
\hline 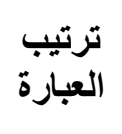 & 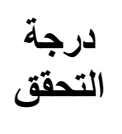 & الإستوبطة & العبارات & العبارة - مقام \\
\hline & & & اتحاد المكتبات المصرية من رسيائل علمية ودوريات & \\
\hline 7 & متوسط &.$V Y$ & التربوية من الموة على الحصول العلمية الأخرى على على الإنترنت والأبحاث & $\mathrm{V}$ \\
\hline$\Lambda$ & متوسط &. .70 & 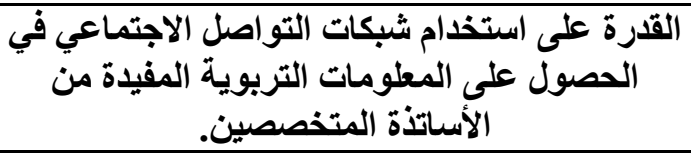 & $\Lambda$ \\
\hline 1. & ضعيفة &. .57 & القدرة على استخدام النقاش العلمي الإكتروني في المعرفة التربوية. & 9 \\
\hline Ir & ضعيفة &..$\varepsilon Y$ & في القرة على المشاركة في حضور البر الإنترنت بمحركات البحريثية & 1. \\
\hline 11 & ضعيفة &. .87 & على شبكات الإنترنت حضور المحاضرات مجال الترقية التصص التربتاحة. & 11 \\
\hline $1 T$ & ضعيفة & .09 & المشاركة في حضور المؤتمرات العلمية التربوية في مصر وخارجهات & $1 Y$ \\
\hline 0 & كبيزة &.$V \varepsilon$ & 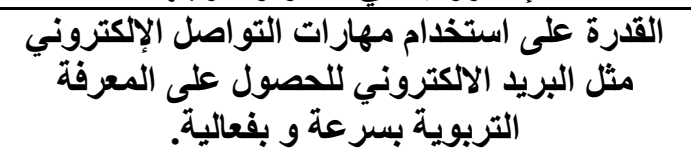 & Ir \\
\hline \multicolumn{2}{|c|}{ متوسطة } &. .74 & المتوسط الإجمالي على المحور & \\
\hline
\end{tabular}

يتضح من الجدول السابق ما يلي :

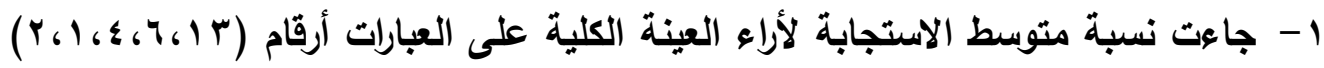
بأنها تتحقق لايهم بلرجة كبيرة ، و ذلك يعني قرتهم على استخدام الحاسب الآلي و الإنترنت بمهارة في إنجاز و إتمام البحث التريوي و القدرة على البحث المتقدم للوصول الى المعلومات التربوية المتاحة ببنك المعرفة المصري و على موقع اتحاد مكتبات الجامعات المصرية و استخدام البريد الالكتروني في الحصول على المعلومات التريوية وذلك يرجع الى أن حاجة الباحثين الماسة لذلك دفعتهم إلى توظيف تلك التكنولوجيا في الحصول على المعرفة خاصة في عصر ارتفاع أسعار الكتب و المطبوعات و قلة دخل 


\section{تصور مقترح لسد الفجوة الرقمية لدى الباحثين التربويين كمدخل لتطوير المعرفة التربوية.}

الباحثين التريويين حيث الغالبية العظمى منهم لا تعمل و تحتاج إلى مصادر المعلومات

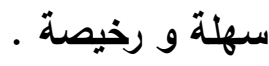

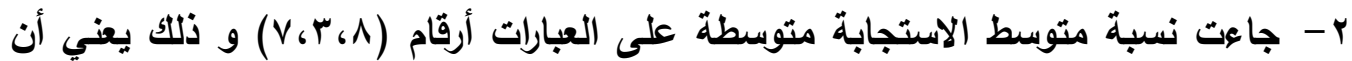
قرتهم في الحصول على المعارف من بعض المواقع العلمية مثل "جوجل سكولر" و المكتبات الرقمية و شبكات التواصل الاجتماعي متوسطة بالرغم من أهمية تلك المواقع الكبيرة و يرجع ذلك إلى اقتصارهم و إكتفائهم بالمعلومات المتاحة على بنك المعرفة المصري و اتحاد مكتبات الجامعات المصرية و يرجع ذلك لعدم تلريبهم على استخدامها و عدم توجيههم إلى استخدامها أو إلى عدم اشتراكهم بها .

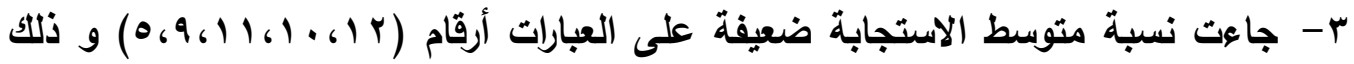
يعني ضعف قدراتهم في استخدام قواعد البيانات العالمية في الحصول على المعرفة ، و كذلك ضعف قدرتهم على النقاش العلمي الاككتروني ،و ضعف قرتهم في حضور المحاضرات الرقمية و المؤتمرات الاكترونية و كذلك ضعف حضور الدورات التدريبية المتاح على الإنترنت، و يرجع ذلك لأسباب كثيرة عدم تدريبيهم على ذلك أثناء إعدادهم ، وعدم استخدامها في كليات التربية في مصر ، مما يجعلها غريبة عليهم و غير مستخدمة لديهم بسبب نقص مهاراتهم في استخد(مها . ع - بلغ إجمالي نسبة متوسط الاستجابة على هذا المحور (ب . . . ) و ذلك يعني تحققه بدرجة متوسطة مما يتطلب زيادة و تنمية قدرات الباحثين في الوصول و النفاذ لمصادر المعرفة

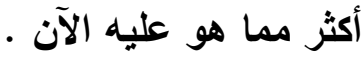

المحور الثاذي : استيعاب المعرشة التزبوية ( تقثيم واستخلاص المعرضة التزبوية ) بعد إجراء المعالجة الإحصائية لاستجابات عينة الدراسة على عبارات الاستبانة جاءت النتائج كما بالجدول التالي : 
تصور مقترح لسد الفجوة الرقمية لدى الباحثين التربويين كمدخل لتطوير المعرفة التربوية.

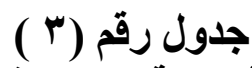

نسبة متوسط استجابة العينة الكلية حول واقع استيعاب المعرفة التربوية

\begin{tabular}{|c|c|c|c|c|}
\hline ترتيب & التحقة - مرجة & متوسطة & العبارات & 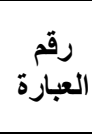 \\
\hline$r$ & متوسطة & $\because V Y$ & 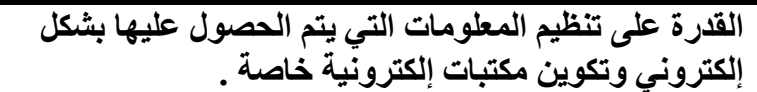 & 1 \\
\hline $1 r$ & ضعيفة &. .57 & 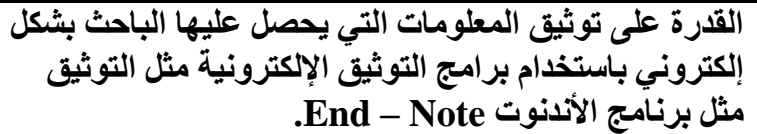 & $r$ \\
\hline 1. & ضعيفة & $.0 \mathrm{~V}$ & 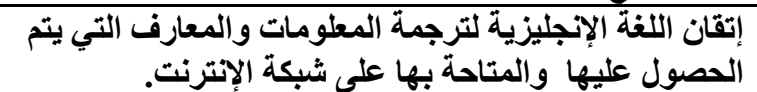 & $r$ \\
\hline$\varepsilon$ & متوسطة &. .21 & 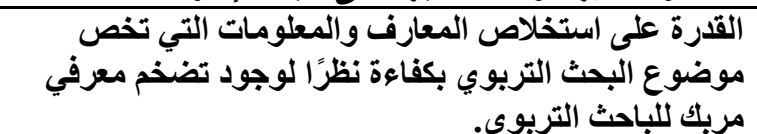 & $\varepsilon$ \\
\hline$r$ & كبيرة &.$V T$ & 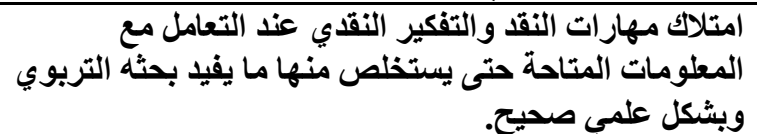 & 0 \\
\hline 0 & متوسطة &.$V$. & 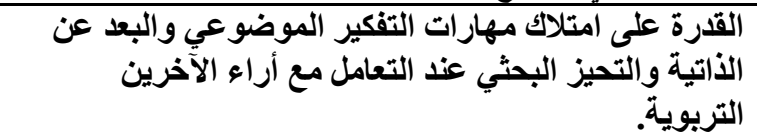 & 7 \\
\hline 1 & كبيرة &. .17 & 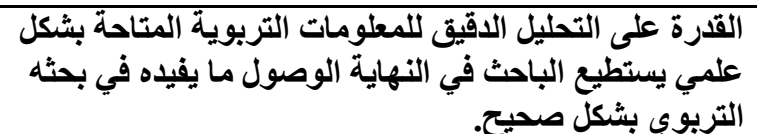 & $\mathrm{V}$ \\
\hline 7 & متوسطة &.$V$ & 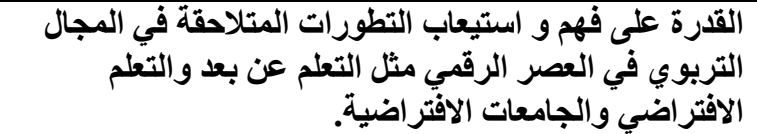 & $\Lambda$ \\
\hline $\mathrm{V}$ & متوسطة &. .79 & 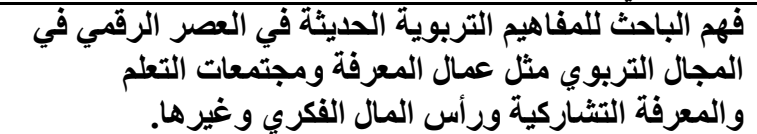 & 9 \\
\hline 11 & ضعيفة & $.0 Y$ & 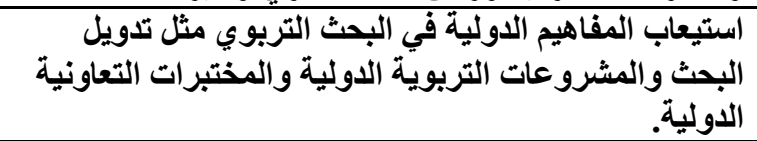 & 1. \\
\hline Ir & ضعيفة & $\because \leqslant r$ & والقدرين معرفى إقامة دولية مشاقتات دولية للحصول معها. على المعلومات & 11 \\
\hline$\Lambda$ & متوسطة &. .79 & استيعاب وفهم المعرفة تبيف التربوية. تكنولوجيا المعلومات في & Ir \\
\hline 9 & ضعيفة & .91 & إتقان منهجيات البحث التربوي الحديثة لاستيعاب أحدث & ir \\
\hline \multicolumn{2}{|c|}{ متوسطة } & .78 & المتوسط الإجمالي على المحور & \\
\hline
\end{tabular}

يتضح من الجدول السابق ما يلي : 
تصور مقترح لسد الفجوة الرقمية لدى الباحثين التربويين كمدخل لتطوير المعرفة التربوية.

- جاعت نسبة متوسط الاستجابة كبيرة على العبارتين (V،0) و ذلك يعني وجود قرة كبيرة لدى الباحثين على تحليل المعلومات التريوية و امتلاكهم لمهارات التفكير النقدي

التي تلزمهم لاستخلاص ما يفيد بحوثهم بشكل صحيح .

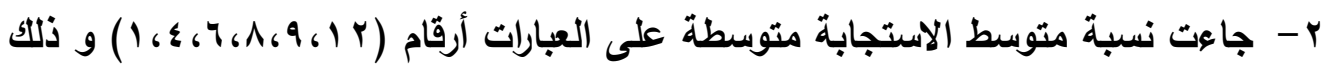
يعني توفر قدرة الباحثين على استخلاص المعلومات و المعارف وسط التضخم الفكري على الإنترنت كانت متوسطة ، و كذلك امتلاكهم مهارات التفكير الموضوعي و عدم التحيز عند تناول تلك المعلومات و القدرة على استيعاب التكنولوجيا المتلاحقة كانت متوسطة ، و قدرة الباحثين على فهم المصطلحات الحديثة في العصر الرقمي وتوظيف تطبيقات تكنولوجيا المطومات في البحث التربوي كانت أيضاً متوسطة مما يعني حاجتها

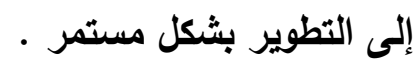

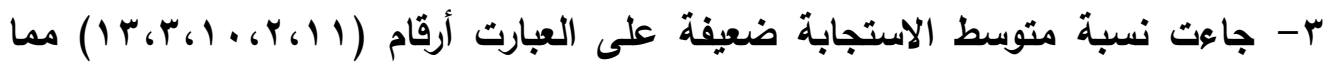
يعني وجود ضعف شديد في قدرات الباحيثن التريويين في إتقان اللغة الإنجليزية و في استيعاب المفاهيم الدولية في البحث التربوي مثل تدويل البحث و المشروعات الدولية ، و ضعف قدتهم في التوثيق الاكتروني و عدم إقامتهم لعلاقات دولية للحصول على المعارف من الآخرين عبر الإنترنت .

ع - جاء إجمالي نسبة متوسط الاستجابة على هذا المحور ( ؟ ؟ ، ) و ذلك يعني أن قدرة الباحثين التريويين على استيعاب المعرفة التريوية و تنظيمها و استخلاصها كانت متوسطة ، و يوجد ضعف في عدة جوانب منها مما يعني الحاجة الماسة إلى تطوير إعداد الباحثين و تدريبهم على ذلك الجاتب .

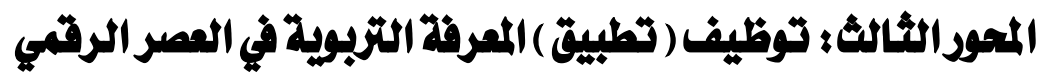

بعد إجراء المعالجة الإحصائية لاستجابات عينة الدراسة على عبارات الاستبانة جاءت النتائج كما بالجدول التالي : 
تصور مقترح لسد الفجوة الرقمية لدى الباحثين التربويين كمدخل لتطوير المعرفة التربوية.

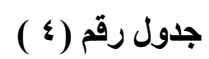

نسبة متوسط استجابة العينة الكلية حول واقع توظيف المعرفة التربوية في العصر الرقمي

\begin{tabular}{|c|c|c|c|c|}
\hline 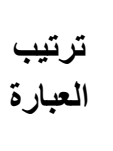 & 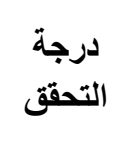 & منتوسطة & العبارات & 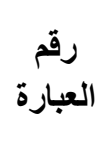 \\
\hline$\wedge$ & 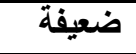 & .97 & القدرة على معرفة مدى جودة البحث العلمي والحكم عليه إلكترونيًا. & 1 \\
\hline$\varepsilon$ & متوسطة & .970 & تالقلدة البياتى إعداد البطاقات والاستبيانات الآكترونية التي تمكن من & $r$ \\
\hline$r$ & كبيزة & $\because v \varepsilon$ & 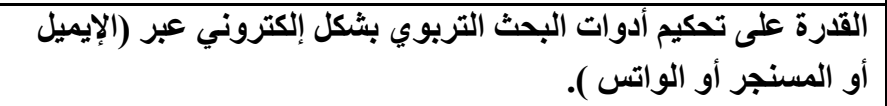 & $r$ \\
\hline$r$ & متوسطة &. .79 & الاستبانة الاكترترونية . . الإنترنت في تطبيق الاستبانات بثكل إلكتروني مثل & $\varepsilon$ \\
\hline 9 & ضعيفة &. .71 & 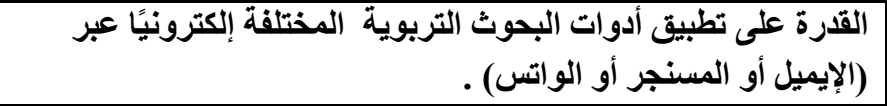 & 0 \\
\hline $1 \pi$ & ضعيفة & $\because \leqslant \Lambda$ & 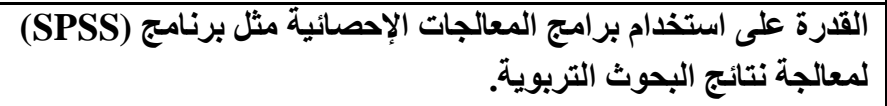 & 7 \\
\hline $1 \varepsilon$ & 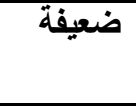 & $\because \leqslant \Lambda$ & واتقسيرة على قراءة نتائج الحاسب الآلي في البرامج الإحصائية & V \\
\hline V & 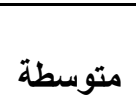 & .97 & وعمل الملفات المختلفة. التكنولوجيا الحديثة في كتابة البحث التربوي & $\Lambda$ \\
\hline Ir & ضعيفة & $\because 0$ & الإكترونية البحثية. & 9 \\
\hline 1 & كبيرة & $\because \vee \wedge$ & 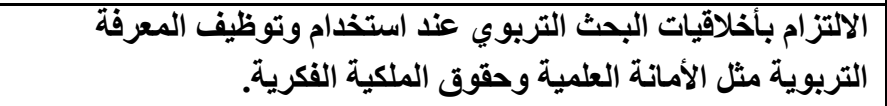 & 1. \\
\hline 1. & 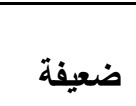 & $\because 04$ & 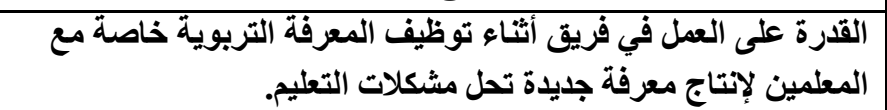 & 11 \\
\hline 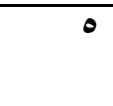 & 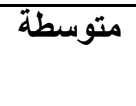 & $\because .70$ & 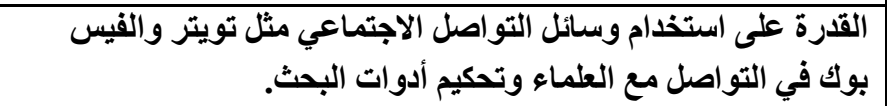 & Ir \\
\hline 7 & متوسطة &. .70 & التربوي خاصة العنادة من وسائل التواصل التي يصب الوتماعي في تطبيق أدوات البحثا. & 14 \\
\hline 11 & ضعيفة & $\because .0 Y$ & محاكاة الواقع التربوي. التكنولوجيا الحديثة في عمل المخططات وخاصة نظم & $1 \leqslant$ \\
\hline 10 & ضعيفة & 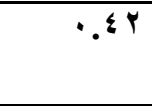 & التصحيح الاكتروني للاختبار الأجهزة المتصلة بالحاسب الآلي مثل أجهزة & 10 \\
\hline & ضعيفة & $\because 7$ & المتوسط الإجمالي على المحور & \\
\hline
\end{tabular}

يتضح من الجدول السابق ما يلي : 


\section{تصور مقترح لسد الفجوة الرقمية لدى الباحثين التربويين كمدخل لتطوير المعرفة التربوية.}

1- جاء إجمالي نسبة متوسط الاستجابة كبيرة على العبارتين أرقام (ب، + 1) و ذلك يعني التزام الباحثين باخلاقيات البحث التريوي عند استخدام و توظيف المعرفة المتاحة على

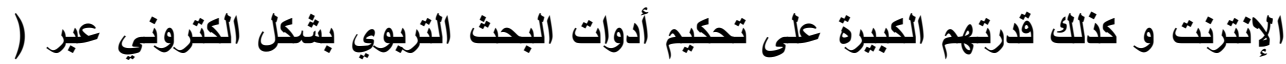
الواتس و الإيميل و الماسنجر ) و ذلك أن الضرورة الملحة لتعلم ذلك جعتهم يتعلمون ذللك و يتقنونه .

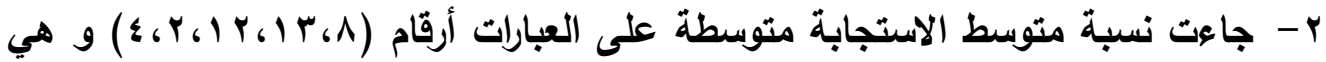
تغني وجود قرة متوسطة لايهم في تطبيق أدوات البحث بثكل إلكتروني ، و كذلك توجد لايهم قدرة متوسطة على إعداد الاستبانات الالكترونية و الاستفادة من شبكات التواصل و التكنولوجيا الحديثة في تطبيقها مما يدعو إلى ضرورة تطوير تلك الجوانب لديهم ، و

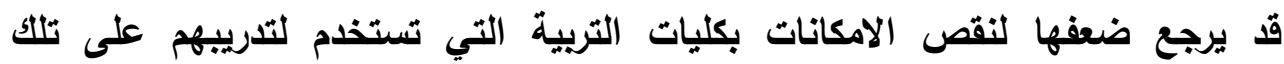
المهارات و عدم إحتواء الخطط الدراسية في مرحلة الدارات العليا على موضوعات تمكنهم من تلك المهارات المطلوية في العصر الرقمي و عدم تطوير تلك الخطط من أجل مواكبتها .

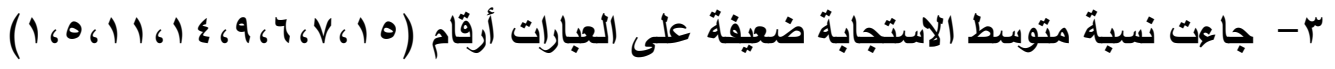
و يغني ضعف قدرات و مستوى الباحثين التريويين في الحكم على جودة البحث أو تطبيق أدوات البحث إلكترونيا عبر الإيميل أو غيرها و ضعف قرتهم في استخدام التكنولوجيا الحديثة لعمل المخططات خاصة نظم المحاكاة للواقع التربوي و ضعف قدرتهم في استخام الحاسب الآلي في عمل المعالجات الإحصائية لنتائج أبحاثهم التربوية وضعف لتفري مستواهم في قراءة نتائج الحاسب الآلي في تلك البرامج الإحصائية ، و ضعف قدراتهم في التصحيح الاكتروني و غيرها من القدرات التي تحتاج إلى تطوير نظراً لأهميتها للباحث

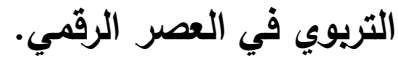


צ - بلغ إجمالي نسبة متوسط الاستجابة على هذا المحور ( •7. • ) و ذلك يعني تحققه بلرجة ضعيفة مما يحتم ضرورة العمل على تطوير جانب توظيف و تطبيق المعرفة التريوية في العصر الرقمي لاى الباحثين التريويين في مصر.

\section{المحور الرابع: توليل وإنتاج المعرقة التزبوية في المصر الرقيمي}

بعد إجراء المعالجة الإحصائية لاستجابات عينة الدراسة على عبارات الاستبانة جاءت

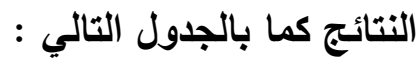

$$
\text { جدول رقم (•) }
$$

نسبة متوسط استجابة العينة الكلية حول واقع توليد وإنتاج المعرفة التربوية في العصر الرقمي

\begin{tabular}{|c|c|c|c|c|}
\hline تربيب & التحقق درجة & متوسطة & العبارات & 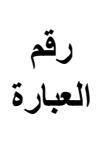 \\
\hline 11 & ضعيفة &. .71 & والتكنوة على إنتاج معرفة تربوية جليدة تواكب المستوى العالمي. & 1 \\
\hline 9 & طتوسد & $.7 \varepsilon$ & البحث التربوي. الباحث التربوي لمهارات التفكير الإبداعي والابتكاري في إنتاج & $r$ \\
\hline 1. & طتوسد & $.7 \leq$ & والقدرة على إنتاج معرفة تربوية تواكب التقلم العلمي والتكنولوجي & $r$ \\
\hline 0 & طة متوسد &. .71 & قالبرة الباحث التربوي على المحافظة على عنصر الأصالة في إنتاج الترقي. & $\varepsilon$ \\
\hline$r$ & كبيرة & $\because \vee v$ & 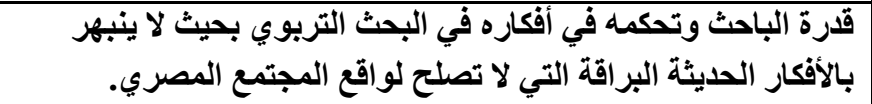 & 0 \\
\hline 7 & متوسد &. .71 & 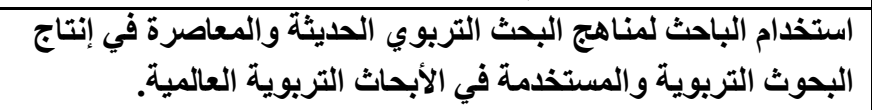 & 7 \\
\hline $1 T$ & ضعيفة & .00 & على تطوير المستقبل البتربو لمداخل استشراف المستقبل لإنتاج معرفة تربوية تعمل & $\mathrm{V}$ \\
\hline Ir & ضعيفة & .7 & 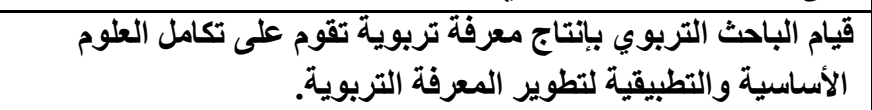 & $\Lambda$ \\
\hline 1 & كبيرة & $\because V V$ & الاتجاهات المعاصرة في البحث التربوي لقضائ التربوي. تريوية معاصرة تساير & 9 \\
\hline $\mathrm{V}$ & طتة متوس &. .77 & بينية تحقى لتحقيق التكامل بين التخصل المعرفة التربوية. & 1. \\
\hline$r$ & كبيرة &.$\vee v 0$ & اختيار الباحث التريوي لموضوعات معاصرة يقوم بلر استها تتناسب & 11 \\
\hline
\end{tabular}


تصور مقترح لسد الفجوة الرقمية لدى الباحثين التربويين كمدخل لتطوير المعرفة التربوية.

\begin{tabular}{|c|c|c|c|c|}
\hline تربيب & التحقق & متوسطة & العبارات & 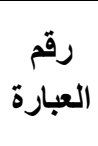 \\
\hline & & & ملها. احتياجات المجتمع المعاصرة وتستفيد من معطيات العصر في & \\
\hline$\Lambda$ & طة متوسد &. .77 & التربوية الوطنية من أجل الباحث للمعيير والمؤشرات المعرفة الترلية في دراسته للقضايا في المجتمع & ir \\
\hline $1 \leqslant$ & ضعيفة & .00 & وإتقان الباحث لاستخدام المداخل التربوية من أجل تطويرها حتى لقياس تواكب أداء النظم التعليمية الخارجي. & ir \\
\hline 10 & ضعيفة & $\because \leqslant V$ & مشتركة مع جهادة من التكنولوجيا الحديثة في التواصل لتطوير المعرفة التربوية في المجتاج بحوث تربوية. & $1 \leq$ \\
\hline$\varepsilon$ & طتة متد & $\because V Y$ & والمخططات والباحث التربوي على تلخيص نتائج أبحاثه بشكل علمي والجداول وتمثيلها بشكل إلكتروني يسهل & 10 \\
\hline \multicolumn{2}{|c|}{ متوســـة } & .70 & المتوسط الإجمالي على المحور & \\
\hline
\end{tabular}

يتضح من الجدول السابق ما يلي :

1 - جاءت نسبة متوسط الاستجابة كبيرة على العبارات أرقام (11، 9، 9) و ذلك يعني امتلاك الباحثين التريويين القدرة على اختياز القضايا التريوية المعاصرة لكي يدرسها كما أنه لا ينبهر بالأفكار البراقة لكنه يدرس قضايا تفيد في اصلاح الواقع التريوي بالمجتمع المصري.

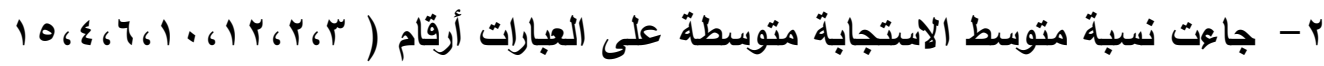
) و ذلك يعني أن قدرة الباحثين ضعيفة في استخدام المخططات و الرسومات و الجداول بشكل الكتروني ، و وكذلك قرتهم متوسطة على المحافظة على الأصالة في العصر الرقمي ،و كنلك قدرتهم على استخدام مناهج البحث الدديثة و أيضاً عمل و دراسات تكاملية و بينية كاتت متوسطة ، استخدام الباحثين للمعايير و المؤشرات الدولية في دراسة القضايا المحلية من أجل تطويرها وتطوير المجتمع المحلي كانت متوسطة . 


\section{تصور مقترح لسد الفجوة الرقمية لدى الباحثين التربويين كمدخل لتطوير المعرفة التربوية.}

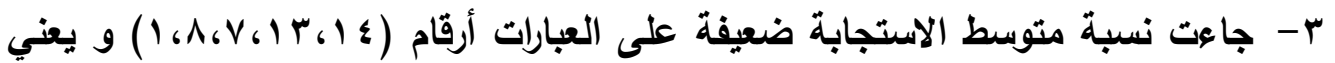
ضعف قرتهم في إنتاج معرفة تربوية تواكب التقدم التكنولوجي على مستوى العالم ، و ضعف القيام بأبحاث تحقق تكامل العلوم الأساسية و التطبيقية ، و استخدام المنهج الاستشراقي و ضعف إتقان الباحث للمداخل الحديثة في قياس أداء المؤسسات التعليمية في العصر الرقمي، و ضعف توظيف التكنولوجيا الحديثة في التواصل لإنتاج بحوث تريوية مشتركة مع جهات دولية لتطوير المعرفة التريوية في المجتمع . צ - بلغ إجمالي نسبة متوسط الاستجابة على هذا المحور (010, •) و ذلك يعني أن قدرة الباحثين التريويين على إنتاج و توليد المعرفة التربوية في العصر الرقمي كاتت متوسطة و من ثم يجب تطوير قدراتهم في ذلك الجانب لأن الوظيفة الرئيسية لهم هي إنتاج

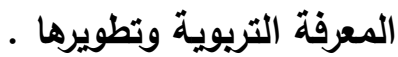

\section{المحور الثامس : ثشر وتوزيع المعرفة التزبوية في المصر الرقمي}

بعد إجراء المعالجة الإحصائية لاستجابات عينة الدراسة على عبارات الاستبانة جاءت النتائج كما بالجدول التالي : 
تصور مقترح لسد الفجوة الرقمية لدى الباحثين التربويين كمدخل لتطوير المعرفة التربوية.

جدول رقم (7)

نسبة متوسط استجابة العينة الكلية حول واقع نشر وتوزيع المعرفة التربوية في العصر الرقمي

\begin{tabular}{|c|c|c|c|c|}
\hline ترتباب & 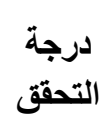 & متوسطة & 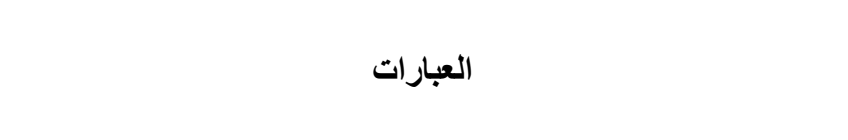 & العبارة - مقام \\
\hline 1 & ضعيفة & $\because \bullet \mathrm{V}$ & القدرة على عمل مدونات شخصية لنشر إنتاجه العلمي التربوي بها. & 1 \\
\hline$\varepsilon$ & ضعيفة & .01 & 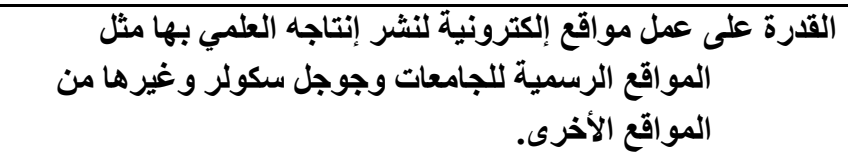 & r \\
\hline $\boldsymbol{0}$ & ضعيفة &. .49 & القدرة على نشر إنتاجه العلمي بالدوريات التربوية التي تصدر بشكل & $r$ \\
\hline 11 & ضعيفة & 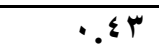 & نشر إنتاجه العلمي بالتجمعات العلمية البحثية على الإنترنت. & $\varepsilon$ \\
\hline 7 & ضعيفة &.$\leqslant 0$ & إنتاجه العلمي بـلى التواصل بشكل إلكتروني مع دور النشر المختلفة لنشر & 0 \\
\hline $\mathrm{V}$ & ضعيفة &.$\leqslant 0$ & للاستفادة منها. & 7 \\
\hline$r$ & ضعيفة & $\because 0 \leq$ & وكيفية الوصتول شبكات التواصل الاجتماعي لتعريف الآخرين بإتتاجه العلمي & $\mathrm{V}$ \\
\hline Ir & ضعيفة & 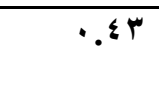 & قدرة الباحث للإسراع من نش انتشار أبحاث التربوية في دور نشر ومجلات تربوية. & $\Lambda$ \\
\hline ir & ضعيفة &.$\because Y$ & مشرفة الباحث لمعايير وشروط إنتاجه التربوي دولثر الاولي والالتزام بها لتسهيل & 9 \\
\hline 1. & ضعيفة & 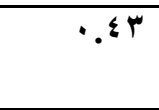 & تنشرويد دور النشر العلمي التي لها مواقع إلكترونية بملخصات أعماله & 1. \\
\hline $1 \varepsilon$ & ضعيفة &.$r q$ & 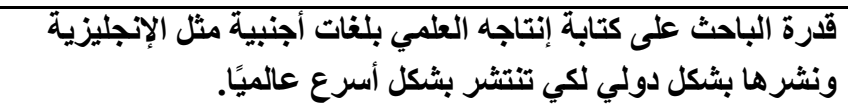 & 11 \\
\hline$\Lambda$ & ضعيفة &..$\leqslant 0$ & 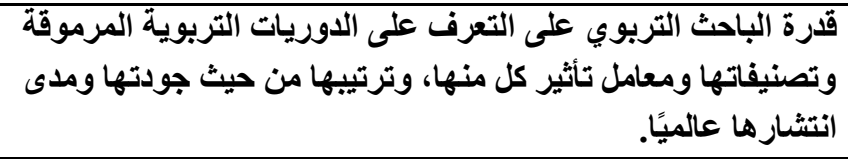 & Ir \\
\hline 9 & ضعيفة &..$\leqslant$ & 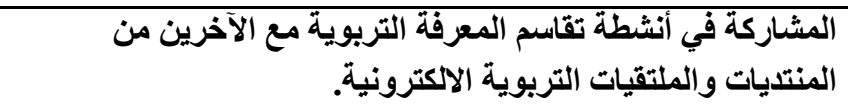 & ir \\
\hline$r$ & ضعيفة & .04 & إنتاجه العلمي لإفادة الآخرين بحافة البى على حقوق ملكيته الفكرية عند نشر & $1 \leq$ \\
\hline & ضعيفة & $\because \leqslant 7$ & المتوسط الإجمالي على المحور & \\
\hline
\end{tabular}

يتضح من الجدول السابق ما يلي : 


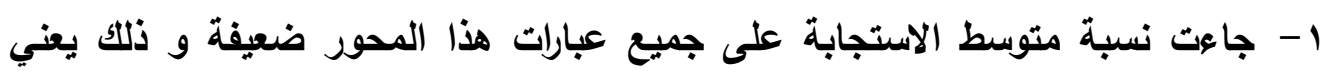
وجود ضعف شديد في قدرات الباحثين التريويين الدذكورة بالجدول السابق و ضعف قررتهم على نثر و تداول المعرفة التريوية في العصر الرقمي و وجود قصور شديد في ذلك و وجود حاجة شديدة لديهم لتنمية ذلك الجانب مما يساعدهم على نشر أبحاثهر العلمية و إنتاجهم التربوي في المستقبل و تداوله مع الأخرين داخل و خارج الوطن.

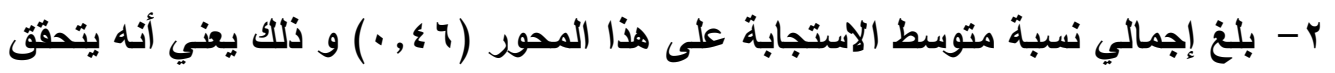
بدرجة ضعيفة عند الباحثين التريويين و ريما يرجع ذلك لعدم مرور غالبية الباحثين بأي خبرة في مجال النثر العلمي و من ثم لم يبحثوا عن تعلم تلك القدرات و المهارات ، و

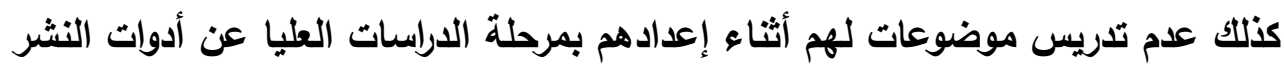
المحلية و الدولية و أنواعها و آلية التعامل معها و غيرها من المطلومات اللازمة للباحث

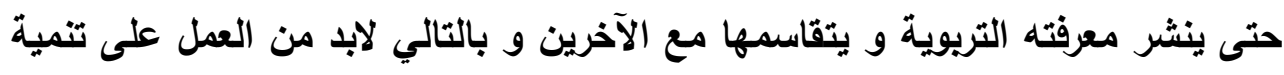
ذلكك الجانب وزيادة معرفة و قدرة الباحثين التربويين في نشر و توزيع المعرفة التربوية

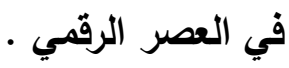
r- بلغ إجمالي نسبة متوسط الاستجابة على جميع محاور الاستبانة وفقاً لأراء العينة

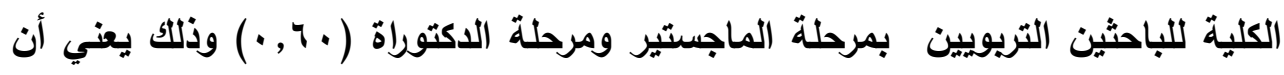
جميع المحاور تتحقق بدرجة ضعيفة ، وذلك يغنى وجود الفجوةالرقمية لاى الباحثين

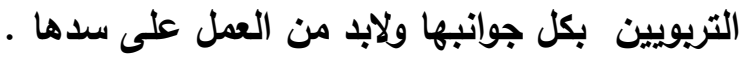


تصور مقترح لسد الفجوة الرقمية لدى الباحثين التربويين كمدخل لتطوير المعرفة التربوية.

ثانيا : حساب دلالة الفروق بين أراء عينات الدراسة حول محاور الاستبانة.

( أ ) : حساب دلالة الفروق بين استجابات الباحثين بمرحلتي الماجستير و الدكتوراة حول واقع الفجوة الرقمية للدي الباحثين التربويني.

وقد استخدم اختبار (T-Test) لمعرفـة هل هنـاك فروق ذات دلائة إحصـائية بين

استجابات الباحثين بمرحلتي الماجستير والدكتوراة حول واقع الفجوة الرقمية لدي الباحثين التريويين أم لا ،وجاءت النتائج كما بالجدول التالي:

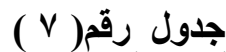

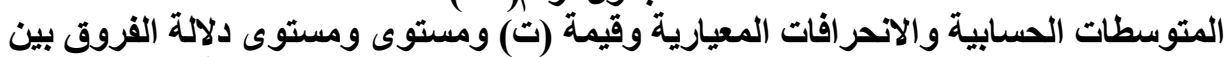

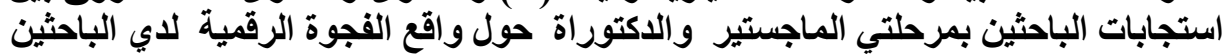
التربويين

\begin{tabular}{|c|c|c|c|c|c|c|}
\hline مستوى الدلالة & قيمةه ت & الحرية & الأنحرافياري & المتوسط & المجموعة & المحور \\
\hline \multirow{2}{*}{ غيز } & \multirow[b]{2}{*}{$.1 \vee \mu$} & \multirow[b]{2}{*}{ YYI } & 7.190 & $r \varepsilon .0$. & الباحثون بمر حلة المبتيز & \multirow{2}{*}{ 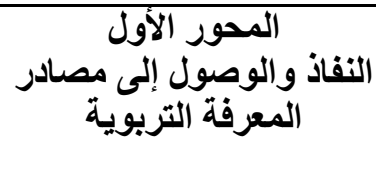 } \\
\hline & & & $\varepsilon .1 \cdot 1$ & 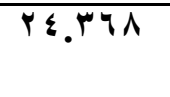 & الباحثون بمر حلة & \\
\hline \multirow{2}{*}{ غيزي } & \multirow{2}{*}{$.0 \leq r$} & \multirow[t]{2}{*}{ YYI } & $7.1 Y \Lambda$ & $r \varepsilon .0 Y V$ & الباحثون بمرحلة المستير & \multirow{2}{*}{ 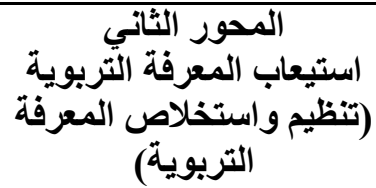 } \\
\hline & & & \&.91. & $Y \leq .9 \leq V$ & الباحثونب مرحتلة الأنور اة & \\
\hline \multirow{2}{*}{ غيز } & \multirow{2}{*}{$.7 \leq 7$} & \multirow[t]{2}{*}{ YYI } & $1.19 \mathrm{~V}$ & YA.YYO & الباحثُون بمرحلة المبر & \multirow{2}{*}{ 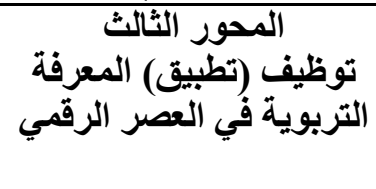 } \\
\hline & & & V.rYA & YA.qYI & الباحثنون بمرحلة الداة & \\
\hline \multirow[t]{2}{*}{ دالة* } & \multirow[t]{2}{*}{$r . \varepsilon \cdot \Lambda$} & \multirow[t]{2}{*}{ YYI } & $\Lambda .71 \wedge$ & $r q . V \leqslant r$ & الباحثون بمر حلة المستير & \multirow{2}{*}{ 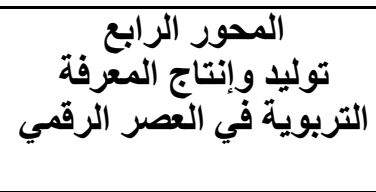 } \\
\hline & & & V.VPq & r..9.1 & 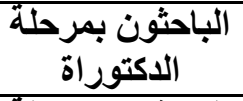 & \\
\hline \multirow{2}{*}{ دالةث* } & \multirow{2}{*}{ r.VYA } & \multirow[t]{2}{*}{ YYI } & 7.010 & 19.909 & الباحثون بمرحلة & \multirow{2}{*}{ التربوية في المتوزيع المعرفة الخامسة الرقمي } \\
\hline & & & $\varepsilon . \leqslant \leq 0$ & 18.198 & الباحثون بمرحلة & \\
\hline \multirow[t]{2}{*}{ غالة } & \multirow[t]{2}{*}{1.199} & \multirow[t]{2}{*}{ YYI } & 11.179 & $1 Y 7.90 \%$ & الباحثون بمرجئة الماجير & \multirow{2}{*}{ 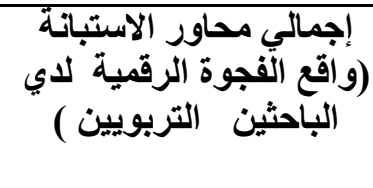 } \\
\hline & & & $r \varepsilon .9 r r$ & TYY.rEY & الباحثتن بمرحلة الاكتوراة & \\
\hline
\end{tabular}


يتضح من الجدول السابق ما يلي:

ا- لا توجد اي فروق ذات دلالة إحصائية بين أراء الباحثين بمرحلة الماجيستير وأراء الباحثين بمرحلة الدكتوراة حول المحور الأول و الثاني و الثالث ، أي أنه لا توجد فروق بينهم في مستوى مهاراتهم وقدراتهم في النفاذ و الوصول إلى مصادر المعرفة التربوية و استيعابها و توظيفها في العصر الرقمي ·

r- توجد فروق ذات دلالة إحصائية بين بين أراء الباحثين بمرحلة الماجيستير و الباحثين بمرحلة الاكتوراة حول المحور الرابع و المحور الخامس لصالح طلاب مرحلة الماجيستير و ذلك يعني أن قرة و مهارة الباحثين مرحلة الماجيستير في توليد وإنتاج المعرفة التريوية في العصر الرقمي أعلى من الباحثين مرحلة الدكتوراة ، و كذلك تميزهم عليهم أيضاً في نشر و توزيع المعرفة التريوية في العصر الرقي و ريما يرجع ذلك لأن طلاب الماجيستير أصبحوا مطالبين بنشر بحث من رسالة الماجستير ،وقد مروا بتلك الخبرة أما طلاب الدكتوراة لم يمروا بها في مرحلة الماجيستير برغم أن ذلك مطلوب منهم في مرحلة الدكتوراة حيث أنه لا يمنح الارجة العلمية إلا بعد نشر بحثين من رسالة الدكتوراة . ب- لا توجد فروق ذات دلالة إحصائية بين أراء الباحثين بمرحلة الماجيستير والباحثين بمرحلة الدكتوراة حول إجمالي جميع محاور الاستبانة أي أن الباحثين بمرحلة الماجيستير و مرحلة الدكتوراة مستوا هم متقارب وضعيف في تلك الجوانب .

\section{( ب ) حساب دلاكلة الثروق بينز استجابات الباحثين و الباحثات حول واقع الفجوة الرقمية لدي}

\section{الباحثين الإبميمين.}

وقد استخدم اختبار (T-Test) لمعرفة هل هناك فروق ذات دلالة إحصائية بين استجابات الباحثين( الأكور) والباحثات (الإناث) حول واقع الفجوة الرقمية لاي الباحثين التربويين أم لا ، وجاءت النتائج كما بالجدول التالي: 


\section{تصور مقترح لسد الفجوة الرقمية لدى الباحثين التربويين كمدخل لتطوير المعرفة التربوية.

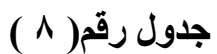

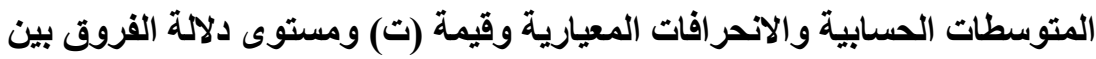

استجابات الباحثين و الباحثات حول واقع الفجوة الرقمية لاي الباحثين التريويين

\begin{tabular}{|c|c|c|c|c|c|c|}
\hline مستوى الدلاكة & قيمة ت & الحرية & المعياري & المتوسط & المجموعة & المحور \\
\hline \multirow[b]{2}{*}{ غيلة } & \multirow[b]{2}{*}{$.9 \leq}$. & \multirow[b]{2}{*}{ YYI } & $0.1 \%$ & $r \leq . q \leq 1$ & الباحثون & \multirow{2}{*}{$\begin{array}{c}\text { النفاذ و الوصول المحور الأولى مصادر } \\
\text { المعرفة التربوية }\end{array}$} \\
\hline & & & 0.9 .9 & $Y \leqslant . \leqslant T V$ & الباحثات & \\
\hline \multirow[b]{2}{*}{ غيلة } & \multirow[b]{2}{*}{$\because 9 r \varepsilon$} & \multirow[t]{2}{*}{ YY } & $0.0 \mu V$ & YO.YMA & الباحثُون & \multirow{2}{*}{ 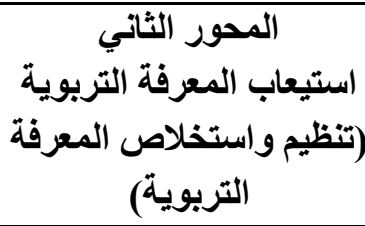 } \\
\hline & & & $0.7 \mathrm{~V}$. & $r \varepsilon . \Delta r r$ & الباحثات & \\
\hline \multirow[b]{2}{*}{ دالة* } & \multirow[b]{2}{*}{$\varepsilon . \wedge \cdot \varepsilon$} & \multirow[t]{2}{*}{ YM } & V.VTr & rq.V T & الباحثون & \multirow{2}{*}{ تلترظيف (تطبيق) المعرفة الثرية } \\
\hline & & & $1.9 \ldots$ & $r \leqslant . \leqslant$. & الباحثات & \\
\hline \multirow{2}{*}{ غيل } & \multirow[t]{2}{*}{$.00 \leqslant$} & \multirow[t]{2}{*}{ YY } & $\wedge . \leqslant \wedge 0$ & rq.. \&. & الباحثون & \multirow{2}{*}{ التربوية في إلتتاج المعرفة الرقة الرقيع } \\
\hline & & & A.Yqu & Y9.74 & الباحثات & \\
\hline \multirow[b]{2}{*}{ دالة** } & \multirow[b]{2}{*}{$r . \& \vee \wedge$} & \multirow[t]{2}{*}{ YYI } & $\varepsilon .9 V$. & $1 V .91$. & الباحثون & \multirow{2}{*}{ التربوية وتوزيع العصر المعرفة الخمب } \\
\hline & & & $7.7 \leqslant r$ & $r \cdot .7 \wedge q$ & الباحثات & \\
\hline \multirow{2}{*}{ غير } & \multirow[t]{2}{*}{$\cdot .9 \cdot 1$} & \multirow[t]{2}{*}{ YYI } & rV.riA & 197.97. & الباحثون & \multirow{2}{*}{ (الجمعالي محاور الاستبانة } \\
\hline & & & rq. $1 \leqslant q$ & IrT.O. & الباحثات & \\
\hline
\end{tabular}

*" الفروق دالة عنل مستوى (0. . . ).

يتضح من الجدول السابق ما يلي:

ا - لا توجد أي فروق ذات دلالة إحصائية بين استجابات الباحثين ( الأكور) و الباحثات

( الإناث) حول المحور الأول والثاني و الرابع ، أي أنهم لهم نفس المستوى في

الوصول و النفاذ إلى مصادر المعرفة التريوية ، و في استيعابها و كذلك في توليد و

إنتاج المعرفة التريوية في العصر الرقمي . 


\section{تصور مقترح لسد الفجوة الرقمية لدى الباحثين التربويين كمدخل لتطوير المعرفة التربوية.}

r- توجد فروق ذات دلالة إحصائية بين استجابات الباحثين و الباحثات حول المحور الثاثث و هو توظيف ( تطبيق) المعرفة التريوية في العصر الرقمي و ذلك لصالح الذكور أي أن مستوى الباحثين في ذلك أعلى من الباحثات في ذلك الجاتب و ريما يرجع ذلك لفروق فردية بين الجنسين.

r- توجد فروق ذات دلالة إحصائية بين استجابات الباحثين و الباحثات حول المحور الخامس و هو نثر و توزيع المعرفة التريوية في العصر الرقمي و ذلك لصالح الإناث و ريما يرجع ذلك لحرص الباحثات و اهتمامهم بمعرفة اجراءات النشر و أهيتها نظراً لحاجتهم الماسة الى المنح و الاهتمام بذلك أكثر من الباحثين. ع - لا توجد فروق ذات دلالة إحصائية بين استجابات الباحثين و الباحثات حول جميع محاول الاستبانة و ذلك يعني أن جميع الباحثين و الباحثات متفقين في ضعف داتف مستواهم في جوانب الفجوة الرقية المختلفة مما يتطلب العمل على سدها لايهخ جميعاً .

\section{* ملغص ثتائج الدراسة الميليانية :}

\section{تصلغص ثتائج الدراسل الميلانية فيما يلي :}

1- بلغ إجمالي نسبة متوسط الاستجابة لاستجابات العينة الكلية على محور واقع النفاذ والوصول إلى مصادر المعرفة التريوية (ז7..) و ذلك يعني تحققه بدرجة متوسطة مما يتطلب زيادة و تنمية قدرات الباحثين في الوصول و النفاذ لمصادر المعرفة. r-جاء إجمالي نسبة متوسط الاستجابة على محور واقع استيعاب المعرفة التريوية (تنظيم واستخلاص المعرفة التربوية) (ع ب, ·) و ذلك يغني أن قدرة الباحثين التريويين على استيعاب المعرفة التريوية وتنظيمها واستخلاصها كانت متوسطة ، و يوجد ضعف في عدة جوانب منها مما يعني ضرورة السعي نحو تطوير إعداد الباحثين و تدريبهم على ذللك الجانب المهم للباحث في العصر الرقمي . 


\section{تصور مقترح لسد الفجوة الرقمية لدى الباحثين التربويين كمدخل لتطوير المعرفة التربوية.}

r- جاء إجمالي نسبة متوسط الاستجابة على محور توظيف (تطبيق) المعرفة التريوية في العصر الرقمير (• (. ·) و ذللك يعني أنه يتتحقى بلرجة ضعيفة مما يحتم ضرورة العمل على تظوير جانب توظيف وتطبيق المعرفة التريوية في العصر الرقمي لاى الباحثين التريويين في مصر.

ع - جاء إجمالي نسبة متوسط الاستجابة على محور توليد وإنتاج المعرفة التريوية في العصر الرقمي (ه 7, •) و ذلك يعني أن قدرة الباحثين التربويين على إنتاج و توليا المعرفة التريوية في العصر الرقمي كانت متوسطة و من ثم يجب تطوير قدراتهم في ذلك الجانب لأنه مهم جدا لهم من أجل إنتاج المعرفة التريوية وتطويرها .

ه- جاء إجمالي نسبة متوسط الاستجابة على محور نشر وتوزيع المعرفة التربوية في العصر الرقمي († ؛ , ·) و ذلك يعني أن قدرة الباحثين التريويين على نثر وتوزيع المعرفة التريوية في العصر الرقمي توجد لايهم بلرجة ضعيفة ولابد من العمل على سد ذلك الضعف لديهم. צ- بلغت نسبة متوسط الاستجابة على جميع محاور الاستبانة (واقع الفجوة الرقمية لاي الباحثين التريويين ) وفقاً لأراء العينة الكلية للباحثين التريويين بمرحلة الماجستير ومرحلة الاكتوراة (• ج, •) وذلك يعني أن جميع المحاور تتحقق بدرجة ضعيفة ، وذلك يعنى وجود جوانب الفجوة الرقمية لاى الباحثين التربويين ولابد من العمل على سدها و القضاء عليها من أجل تظوير المعرفة التريوية. V- دلالة الفروق بين إجمالي استجابات الباحثين بمرحلة الماجستير و إجمالي استجابات الباحثين بمرحلة الدكتوراة حل واقع الفجوة الرقمية لدي الباحثين التريويين وجد أنه لا توجد اي فروق ذات دلالة إحصائية بين استجابات الباحثين بمرحلة الماجستير و استجابات الباحثين بمرحلة الدكتوراة حول المحور الأول و الثاني و الثالث ، ولكن توجد فروق ذات دلالة إحصائية بين استجابات الباحثين 


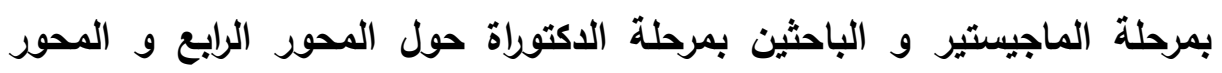

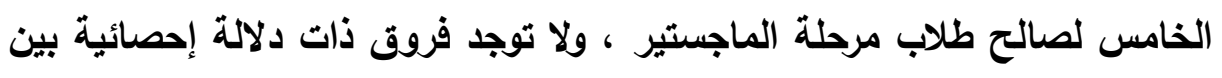

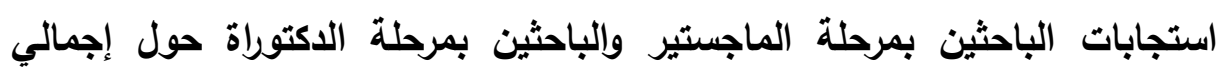
جميع محاور الاستبانة أي أن الباحثين بمرحلة الماجستير و مرحلة الدكتوراة مستواهم متقارب و ضعيف في تلكل الجوانب . ^- دلالة الفروق بين إجمالي استجابات الباحثين وإجمالي استجابات الباحثات حول

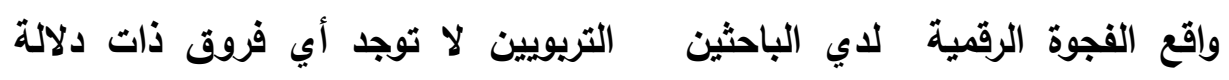

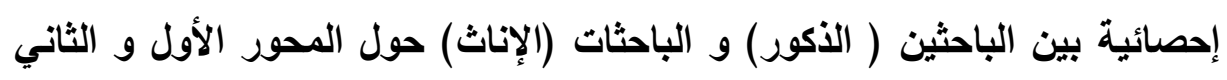

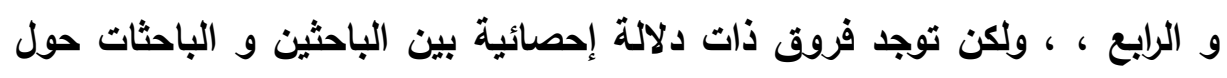
المحور الثالث و ذلك لصالح الذكور ،و توجد فروق ذات ذات دلاتلة إحصائية بين

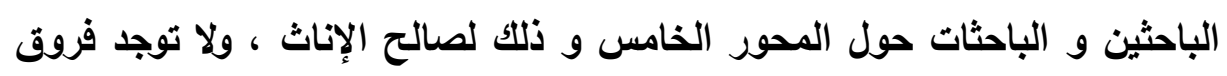
ذات دلالة إحصائية بين الباحثين و الباحثات حول جميع محاور الاستبانة و ذلك

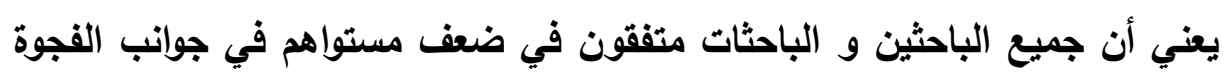
الرقمية المختلفة مما يتطلب العمل على سدها لديهم جميعاً .

ومن ثَم نظراً لما جاء بالدراسة النظرية من أهية سد الفجوة الرقمية لاى الباحثين

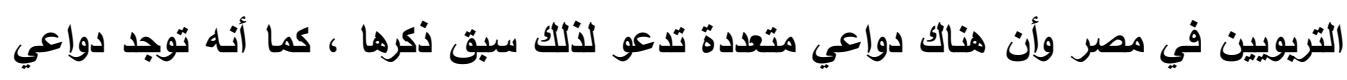

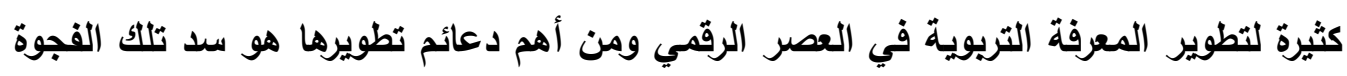

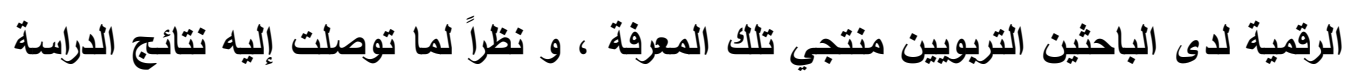
الميدانية من وجود الفجوة الرقمية بكل جوانبها لاى الباحثين التربويين مما يثكل عائقاً كبيرا في طريق إنتاج المعرفة التربوية ويحد من تطويرها في مصر ، فإنه بالتالي سيتم في الجزيء التالي من هذه الدراسة وضع تصور المقترح لسد الفجوة الرقمية لاى الباحثين التربويين لتظوير المعرفة التريوية في مصر. 


\section{التصور المقترح لسل الفجوة الرقبية للى الباحثين التربويين لتطوير المعرفة التربوية}

من أهم أهداف الدراسة الحالية وضع تصور مقترح لسد الفجوة الرقمية لدى

الباحثين التريويين في القطاع التربوي كمدخل لتطوير المعرفة التريوية خاصة في العصر الرقمي ، و هذا الجزء من الدراسة جاء ليجيب عن التساؤل السادس و الأخير من تساؤلات الاراسة الحالية . ترئ. و قد توصلت الدراسة النظرية في الدراسة الحالية إلى أنه يجب على الباحثين التريويين مواكبة العصر الرقمي و التمكن من مجموعة كبيرة من القدرات و المهارات و هي القدرة على النفاذ و الوصول إلى المعرفة التريوية ، و استيعاب المعرفة التربوية ، و القدرة على توظيف و تطبييق المعرفة التريوية ، و القدرة على إنتاج المعرفة التريوية و توليدها ، و كذلك القدرة على نشر و توزيع المعرفة التريوية في العصر الرقمي و في حالة عدم تمكن الباحث من تلك الجوانب السابقة التي تعد جوانب للفجوة الرقمية فانه يجب العمل على سد تلك الفجوة الرقمية لايهم و التي لها أسباب متعددة. و توصلت الدراسة الميدانية إلى وجود قصور كبير لدى الباحثين التريويين عن مواكبة العصر الرقمي و توجد فجوة رقمية لايهم بجوانبها المختلفة ، و ترجع تلك الفجوة الرقمية إلى وجود أسبابها بارجة كبيرة لديهم مما ترتب عليه وجود تلك الفجوة الرقمية لايهم ، مما يعوق تطوير المعرفة التريوية أو حتى إنتاجها بشكل سليم و صحيح ، و من ثم جاء التصور المقترح التالي ليعمل على سد الفجوة الرقمية لاى الباحثين التربويين مما يؤدي الى تطوير المعرفة التريوية ، و يتضمن التصور المقترح فلسفته و أهم منطلقاته و أهدافه و المشاركين في تنفيذه ، و محاوره و الضمانات اللازمة لنجاحه .

\section{أولاء ثلسفة التصور المثتزح وأهم منطاقاته: -}

تنطلق فلسفة التصور المقترح من وجود فجوة رقمية لاى الباحثين التريويين و لها أسباب متعددة كما سبق توضيحه ، و ذلك يعوق تظوير المعرفة التريوية ـ في الوقت 


\section{تصور مقترح لسد الفجوة الرقمية لدى الباحثين التربويين كمدخل لتطوير المعرفة التربوية.}

الأي يوجد فيه توجه للاولة في دستور ع 1 ـ بم إلى ضرورة سد الفجوة الرقمية و محو الأمية الرقمية لاى المواطنين و بالتالي الباحثين هم أول فئة يجب أن يطبق ذلك عليهم و بالتالي جاء التصور المقترح ليضع اجراءات عملية لسد الفجوة الرقمية لدى الباحثين التريويين حتى يتم تطوير المعرفة التريوية في العصر الرقمي ، و بالتالي يقوم التصور المقترح على مجموعة من المنطلقات هي ما يلي:1 - إهتمام الدستور المصري بضرورة القضاء على الأمية الرقمية لدى المواطنين و بالتالي فمن باب أولى الاهتمام بذلك لاى الباحثين التريويين ، حيث تتص المادة

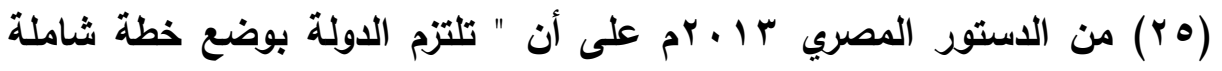
للقضاء على الأمية الهجائية والرقمية بين المواطنين في جميع الأعمار ، و تلتزم بوضع آليات تنفيذها بمشاركة مؤسسات المجتمع المدني و ذلك وفق خطة زمنية محدة " ، ويالتالي لابد من الإسهام في تنفيذ هذه المادة من الاستور و سد الفجوة الرقمية لاى الباحثين التريويين في مصر. r - ضرورة تطوير إعداد الباحثين في العصر الرقمي بشكل يجعلهم مُلمين بكل التقتية الحديثة من أجل تطوير قدراتهم و مهاراتهم اللازمة للتعامل مع العصر الرقمي و كل معطياته الحديثة و المتجددة .

r- أن عملية تطوير قدرات و مهارات الباحثين في التعامل على المعرفة في العصر الرقمي في الحصول عليها و استيعابها و توظيفها سيؤدي الى إنتاج معرفة تريوية جديدة و يسهم في تطوير المعرفة التربوية و التي هي في حاجة ماسة لذلك. ع - إن تطوير أداء الباحثين التريويين في العصر الرقمي و سد الفجوة الرقمية لديهم سيؤدي إلى إنتاج معرفة تريوية تسهم في تحسين الممارسات التريوية في المؤسسات التعليمية و التي هي في أمس الحاجة لذلك التحسين . 


\section{تصور مقترح لسد الفجوة الرقمية لدى الباحثين التربويين كمدخل لتطوير المعرفة التربوية.}

ه- أنه لابد من تحسين حال المعرفة التريوية في مصر والتي أثنارت عدة دراسات أن لايها أزمة خاصة في العصر الرقمي و ذلك يحتم سد الفجوة الرقمية لاى الباحثين التريويين في مصر

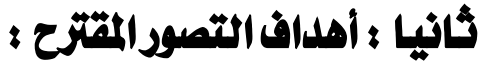

في ضوء فلسفة التصور المقترح و أهم منطلقاته السابقة تتبلور أهداف التصور المقترح فيما يلي :-

1 - وضع آليات و إجراءات تساعد على سد الفجوة الرقمية لاى الباحثين التربويين مما يسهم في تظوير أدائهم في العصر الرقمي ومن ثَّم تطوير المعرفة التريوية في مصر. r - العمل على توضيح أهم ما يجب ان تقوم به كليات التربية من إجراءات تؤدي إلى سد الفجوة الرقمية لاى الباحثين التريويين. r- تحديد الأدوار التي يجب أن تقوم بها المؤسسات التريوية الأخرى مثل ( الأسرة و المدرسة و الإعلام) من أجل المساهمة في سد الفجوة الرقمية لاى الباحثين التربويين في مصر.

ع - مساعدة المسئولين بكليات التربية في إعداد الخطط الاراسية لإعداد الباحثين التريويين على العمل على تطويرها لسد الفجوة الرقمية لايهم في ضوء معطيات العصر الرقمي و في ضوء ما يلزم لتطوير المعرفة التربوية . ه - تحديد الإجراءات و الآليات التي يجب أن تقوم بها مؤسسات المجتمع المدني مثل ) النقابات و الأحزاب السياسية و الجمعيات الخيرية ) في سد الفجوة الرقمية لاى الباحثين التريويين. צ- توضيح الأدوار التي يجب أن يقوم بها أعضاء هيئة التدريس بكليات التربية تجاه سد الفجوة الرقمية لاى الباحثين التريويين بتلك الكليات. 


\section{تصور مقترح لسد الفجوة الرقمية لدى الباحثين التربويين كمدخل لتطوير المعرفة التربوية.}

V- وضع مجموعة من الضمانات التي تساعد على نجاح جهود سد الفجوة الرقمية لاى الباحثين التريويين حتى يسهموا في تطوير المعرفة التريوية في مصر •

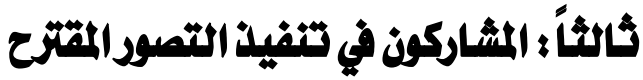

لابد من تعاون بين متخذي القرار في القطاع التريوي في مصر مع العاملين بكليات التربية ، و من أهم المشاركين في تتفيذ التصور المقترح كل العاملين بالقطاع التريوي و متخذوا القرارات و التشريعات التريوية ، وعمداء كليات التربية ووكلاءها و أعضاء هيئة التدريس بها ، بالإضافة إلى مساهمة المسئولين بالمؤسسات التريوية الأخرى بالأسرة و مدارس التعليم قبل الجامعي و وسائل الإعلام المختلفة، و المسئولين عن مؤسسات المجتمع المدني الأخرى ، و كل من يستطيع أن يسهم في سد الفجوة الرقمية لاى الباحثين التريويين بطريقة مباشرة أو غير مباشرة.

\section{كابعاء محاورالتصورالمقتزح}

يشتمل التصور المقترح على عدة محاور و بكل محور مجموعة من الإجراءات التي يجب القيام بها حتى يتم تتفيذه و يتم سد الفجوة الرقمية لاى الباحثين التريويين و تتمثل تلك

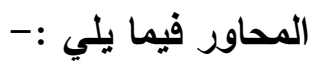

\section{الماحور الأول : تطوير عملية إختيارو قبول الباحثين التزبوبين في المصر الرقيمي.}

حيث إن عملية اختبار وقبول الباحثين التربويين هي مرحلة هامة لأنه يجب أن ياخل نظام الاراسات العليا مدخلات من طلاب لها خلفية تكنولوجية تستطيع التعامل مع العالم الرقي ويمكن تحقيق ذلك وفقاً للإجراءات التالية. 1 - أن لا يكون قبول الباحثين بمرحلة الدراسات العليا بالابلومات المهنية والدبلومة الخاصة وكذلك مرحلة الماجيستير مقتصراً على مجموعة في المرحلة السابقة لأنها طريقة غير كافية لانتقاء الباحثين المتميزين . 


\section{تصور مقترح لسد الفجوة الرقمية لدى الباحثين التربويين كمدخل لتطوير المعرفة التربوية.}

ץ- أن يكون من أهم معايير قبول الطلاب بمرحلة الدراسات العليا إتقانه للفة الإنجليزية و يتم ذلك باختيارات جادة ، لأنها هي اللغة المطلوية للتعامل مع المجتمع الرقمي لوجود أكبر محتوى معرفي مكتوياً بتلك اللغة الإنجليزية وتمكن الباحث منها يؤدي لتمكنه من الاستفادة من ذلك المحتوى المعرفي الضخم.

r- أن يكون من شروط قبول الطلاب بمرحلة الدراسات العليا إتقانه لمهارات التعامل مع التكنولوجيا و الحصول على المعلومات والمعارف من شبكة الإنترنت و من مصادرها بشكل جيا و يتم ذلك بعقد اختبار عملي لهم للتأكد من ذلك. ع - أن يكون أيضاً من ضمن شروط قبول الباحثين وجود خبرة لايهم في العمل بالتدريس لأن فترة عمله بالتدريس تعرفه بالواقع التربوي و مشكلاته التي تستحق الدراسة فتأتي دراساتهم التريوية بها إضافة علمية جديدة و مفيدة و مطورة للواقع التريوي . ه- أن يعقد اختبار تحريري لقبول الباحثين بمرحلة الماجستير للتعرف على مدى امتلاكهم للمعلومات و المعارف الخاصة بالتعامل مع العالم الرقمي ، و كذلك مدى امتلاكهم للقيم الأخلاقية اللازمة لذلك اثناء إعداد البحث العلمي .

\section{المحور الثاذي ؛ - تطوير مملية إعداد الباحثين التزبويمن في المصر الرقيمي .}

حيث إن الباحثين التريويين لابد أن يتم إعدادهم في مرحلة الدراسات العليا بشكل يسهم في سد الفجوة الرقمية لايهم و يتفق مع معطيات العصر الرقمي و أهم الإجراءات اللازمة لتحقيق ذلك ما يلي:-

1 - أن يتم تدريس طلاب الدراسات العليا بجميع الأقسام بكلية التربية مقراً عن التكنولوجيا الحديثة و تطبيقاتها التريوية في كل السنوات الدراسية حتى يلم الطلاب بتلك المعارف و المعلومات عنها و عن إمكانية الاستفادة منها . r- أن يكلف أعضاء هيئة التدريس طلابهم الباحثين التريويين بأعمال بحثية تتطلب منهم الاستفادة من التكنولوجيا الحديثة في إعدادها . 


\section{تصور مقترح لسد الفجوة الرقمية لدى الباحثين التربويين كمدخل لتطوير المعرفة التربوية.}

r- أن تعقد بكليات التربية دورات تدريبية لطلاب الدراسات العليا و الباحثين التربويين حتى يتم إكسابهر مهارات التعامل مع تكنولوجيا العصر الرقمي و تطبيقاتها التربوية. ء - أن تكون جميع التعاملات مع طلاب الدراسات العليا بكليات التربية بشكل الكتروني و جميع الخدمات التي تقدم لهم كذلك حتى يتقتوا توظيف التكنولوجيا طوال فترة حياتهم الدراسية . ه- أن تكون كل نظم تقويم و اختبارات طلاب الدراسات العيا الكترونية بكليات التربية تمشياً مع معطيات العصر الرقمي. צ- أن تعقد مسابقات بكليات التربية للباحثين المتميزين في المهارات التكنولوجية الحديثة و يتم تكريمهم تثجيعا لزملائهم الأخرين على ذلك . - أن يوظف أعضاء هيئة التدريس التكنولوجيا الحديثة أثناء تدريسهم وإعدادهم للباحثين بكليات التربية .

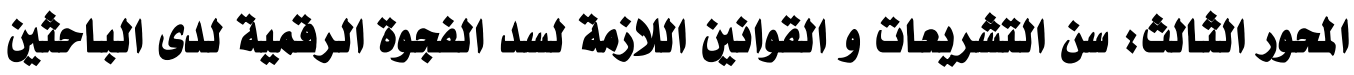 \\ التزبوينئ.}

حيث أن عملية سد الفجوة الرقمية لدى الباحثين التربويين تلزمها حزمة من القوانين و التشريعات التي تنظم ذلك بداية من قبولهم بمرحلة الدراسات العليا و حتى الحصول على درجة الدكتوراة و لتحقيق ذلك لابد من القيام بما يلي:-

1 - تعديل اللوائح الداخلية لكليات التربية بالمرحلة الجامعية الأولى بحيث يتم تضمينها عدداً أكبر من ساعات تدريس التكنولوجيا الحديثة و تطبيقاتها التربوية ، حيث أن غالبية الكليات و منها كلية التربية جامعة سوهاج يتم بها تدريس ساعتين فقط عن تكولوجيا التعليم و بالتالي لابد من تعديل تلك اللوائح بحيث يكون هناك ساعتين كل عام دراسي عن تكنولوجيا التعليم و كيفية توظيفها للاستفادة منها. r - تعديل لوائح الدراسة بالدبلومات المهنية و كذلك الابلوم الخاص في التربية بحيث تحتوي على ساعتان كل عام عن التكنولوجيا الرقمية و كيفية توظيفها في البحث التريوي . 
r- أن تضمن لوائح كليات التربية شرط إتقان اللغة الإنجليزية كشرط قبول بمرحلة الماجيستير حتى يتحسن مستوى الباحثين في البحث و الدراسة بمرحلة الماجيستير و الدكتوراة . ؟ - أن تحتوي لوائح كليات التربية شرطاً آخر لقبول الطلاب كباحثين بمرحلة الدراسات العليا هو اجتياز اختبار عملي و آخر نظري عن كيفية البحث عن المعرفة باستخدام التكنولوجيا الحديثة . الحتية ه- أن تعمم جميع كليات التربية شرط الحصول على شهادة (ICDL) الموجود ببعض الكليات كشرط للتسجيل لارجة الماجيستير بها حتى يتحسن مستوى الباحثين في استخدام الحاسب الآلي في البحث التريوي ·

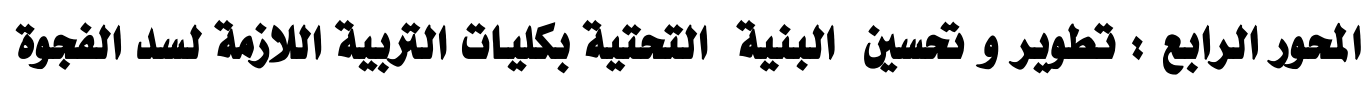 الرقيمية للاى الباحثين.} تعد البنية التحتية لكليات التربية هي العمود الفقري لاعداد الباحثين للعصر الرقمي حيث إنها توفر الوسط الملائم لتعليم و تدريب الباحثين على استخدام تكنولوجيا العصر الرقمي في البحث التربوي و حتى يتم تحسين وتطوير البنية التحتية لكليات التربية اللازمة لسد الفجوة الرقمية لاى الباحثين التربويين لا بل من اتخاذ الإجراعات التالية :1-توفير غرفة مصادر للباحثين بكليات التربية تتوفر بها أجهزة حاسب آلي تكفي لكل الباحثين التريويين المترددين على الكلية. ץ- توفير معامل للحاسب الآلي بكليات التربية متصلة بالإنترنت حتى يمكن تدريب الباحثين على كيفية استخد/مها وتوظيفها في البحث التربوي. ب- توفير شبكة انترنت قوية بكليات التربية وقاعاتها المختلفة تتيح لكل الباحثين الحصول على المعرفة بشكل سهل و تتيح لأعضاء هيئة التدريس الفرصة لتدريب الطلاب الباحثين على كيفية النفاذ و الوصول الى المعرفة بثكل صحيح . 


\section{تصور مقترح لسد الفجوة الرقمية لدى الباحثين التربويين كمدخل لتطوير المعرفة التربوية.}

ع - توفير و تخصيص ميزانية بكليات التربية تكفي متطلبات امتلاك التكنولوجيا الحديثة نظرا لارتفاع تكلفتها و كذللك صيانتها و تجديدها بشكل مستمر حسب مستجدات العصر السريعة.

ه أن توفر كليات التربية للباحثين بكليات التربية اشتراكاً مجانياً في بنك المعرفة المصري و في قواعد البيانات العالمية و في اتحاد مكتبات الجامعات المصرية نظراً لسوء الأحوال الاقتصادية لغالبية الباحثين بتلك الكليات .

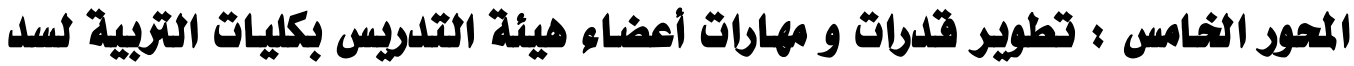

\section{المفجوة الرقيمية للدى الباحثين}

حيث يعد عضو هيئة التدريس هو القائم على عملية إعداد الباحثين التريويين و بالتالي لابد من تسليحه بكل المعارف و المهارات اللازمة للتعامل مع معطيات العصر الرقمي حتى يستطيع نقلها إلى طلابه و لتحقيق ذلك لابد من الإجراءات التالية :1 - أن يتم عقد دورات تدريبية لأعضاء هيئة التدريس على مستجدات العصر الرقمي و كيفية توظيفها في البحث التريوي حتى ينقلوها لطلابهم الباحثين . r- أن تكون هناك حوافز لأعضاء هيئة التدريس المتميزين في مجال تكنولوجيا المعلومات و الاتصالات و عقد مسابقات دورية لذلك لتشجيعهم على متابعة كل ما هو حديث في ذلك

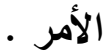

r- أن يتم إلزام أعضاء هيئة التدريس على دمج تكنولوجيا المعلومات و الاتصالات في العملية التعليمية أثناء إعداد طلابهم بشكل تدريجي حتى يتم إتقانها، و ذلك بداية من التدريس و

$$
\text { حتى التقويم و الاختبارات . }
$$

ع - أن يكون من ضمن متطلبات التعيين كعضو هيئة تدريس بعد الحصول على درجة الدكتوراة الحصول على شهادة (ICDL) و إتقان اللغة الإنجليزية تحدثاً و كتاباً مما يسهم في تحسين مستوى أعضاء هيئة التدريس في استخدام تكنولوجيا المعلومات في البحث العلمي و في تدريس طلابهم الباحثين التربويين . 


\section{تصور مقترح لسد الفجوة الرقمية لدى الباحثين التربويين كمدخل لتطوير المعرفة التربوية.}

ه - أن تكون هناك جزاءات و عقويات لأعضاء هيئة التدريس ممن لا يجيدوا التعامل مع العالم الرقمي منهم لأن ذلك يؤثر بشكل سلبي على طلابهم من الباحثين التريويين . צ- عمل حوافز مادية كبيرة لأعضاء هيئة التدريس التريويين الذين ينشروا أبحاثهم العلمية

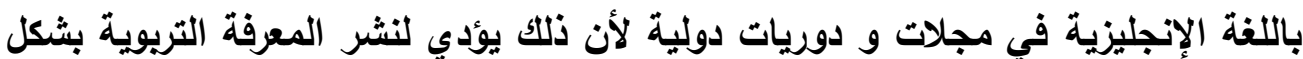
كبير ، و سيتم تعليم ذلك لطلابه الباحثين .

\section{المحود السادس : تبني ادارة الجامعات و إدارات كليات التربية لقضية سلد الفجوة الرقية}

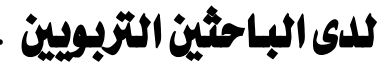

إن تبني إدارة الجامعة و إدارات كليات التربية لقضية سد الفجوة الرقمية لاى الباحثين التريويين سوف يعجل بنجاح ذلك و يتم إنجازه في أسرع وقت ممكن و لكي يحدث ذلك لابد من القيام بالإجراءات التالية :1 - أن تجعل إدارة الجامعة قضية سد الفجوة الرقمية لاى الباحثين بصفة عامة و التربويين بصفة خاصة من أهم أهدافها في خطتها الاستراتيجية وتحدد إجراءات لتنفيذ ذلك الهدف . r أن توفر إدارة الجامعة وإدارات كليات التربية جميع الموارد المادية و المالية اللازمة لسد الفجوة الرقمية لاى الباحثين التربويين أن r- أن تتضمن الخطط الاستراتيجية بكليات التربية هدفاً محورياً و هو سد الفجوة الرقمية لدى الباحثين التريويين وجعله من أهم أهدافها و شحذ الجهود لتنفيذه . צ- أن تعقد الجامعة وكليات التربية مسابقات دورية للباحثين المتميزين في دمج التكنولوجيا المعلومات وأصحاب الاضافات العلمية المتميزة ، وذلك يؤدي إلى تثجيع الباحثين على الاهتمام بسد الفجوة الرقمية لديهم • ه- أن تنظم الجامعات مع كليات التربية مؤتمرات سنوية للتعريف بأحدث المستجدات في العصر الرقمي وكيفية الاستفادة منها و توظيفها في البحث العلمي مما يؤدي إلى رفع ممستوى معرفة الباحثين التريويين بذلك . مئ 


\section{تصور مقترح لسد الفجوة الرقمية لدى الباحثين التربويين كمدخل لتطوير المعرفة التربوية.}

צ- أن تعقد مسابقات لأفضل موقع علمي لعضو هيئة التريس وأيضاً أفضل موقع علمي للباحثين ما يؤدي إلى التنافس العلمي على إتقان ذلك و يسهم في نشر المعرفة بشكل

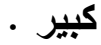

- أن تثكل الجامعة وكذلك كليات التربية لجاناً لمتابعة مستوى الباحثين التريويين في تكنولوجيا المعلومات ، ومدى التحسين في مستواهم و حجم الفجوة الرقمية لايهم مما يؤدي لاتخاذ الإجراءات التي تلزم اتجاه ذلك .

\section{المحور السابع : إسمام مؤسسات المجتمع التزبوية في سلد الثموة الرقمية للدى الباحثين}

الاتزبميسين.

لابد من مساهمة مؤسسات المجتمع التريوية الأخرى في سد الفجوة الرقمية لاى الباحثين التريويين حيث إن كليات التربية بمفردها لا تستطيع ذلك ومن أهم آليات تلك المساهمة ما

$$
\text { يلي :- }
$$

1 - أن تعمل الأسرة على توفير أجهزة الكمبيوتر و الإنترنت لأبنائها كي تتاح لهم فرصة التعامل مع تكنولوجيا العصر الرقمي و التدريب عليها منذ الصغر • ץ- ضرورة قيام الأسرة بتشجيع أبنائها الطلاب والباحثين على استخدام تكنولوجيا العصر الرقمي و توظيفها في البحث العلمي بشكل فعال . r- أن تقوم مدارس التعلم قبل الجامعي بدمج تكنولوجيا العصر الرقمي في المقررات الدراسية المختلفة في جميع سنوات الدراسة و تخصص أجزاء من المقررات الدراسية لإكساب الطلاب المعلومات و كيفية التعامل و الاستفادة من تلك التكنولوجيا في العصول على المعلومات و المعارف المختلفة . ع - أن يتم توظيف تكنولوجيا العصر الرقمي في التدريس و في الاختبارات بمدارس التعلم قبل الجامعي لاكساب الطلاب مهارات التعامل معها بشكل عملي و فعال و إيجابي . ه - أن يتم توفير البنية التحتية و أجهزة الحاسب الآلي و شبكات الإنترنت بمدارس التعلم قبل لجامعي من أجل إتاحة الفرصة لطلابها لاستخدام تلك التكنولوجيا داخلها و إتاحة فرص 


\section{تصور مقترح لسد الفجوة الرقمية لدى الباحثين التربويين كمدخل لتطوير المعرفة التربوية.}

الوصول و النفاذ للعالم الرقمي بتلك المدارس ، خاصة لوجود بيئات و مجتمعات فقيرة محرومة من تلك التكنولوجيا لغلاء تكلقة اقتناءها . צ- أن تقوم وسائل الإعلام المختلفة المسموعة و المقروية و المرئية بنشر الوعي لاى الثباب و خاصة الباحثين التريويين لضرورة الاستفادة من مصادر المعرفة في العصر الرقمي المتاحة على الإنترنت مثل بنك المعرفة المصري و قواعد البيانات العالمية واتحاد المكتبات المصرية و ضرورة توظيفها في البحث العلمي .

المحور الثامز : مساهمة مؤسسات المجتمع الملدذي في سل الفجوة الرقمية للدى الباحثين

التربوينز

حيث إن المؤسسات التريوية بمفردها لا تستطيع القيام بسد الفجوة الرقمية لاى الباحثين التريويين ، ويمكن لمؤسسات المجتمع المدني الأخرى أن تساعدها في ذلك الأمر من خلال

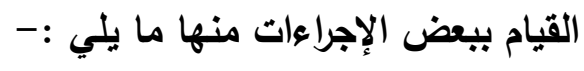

ا- يمكن أن تقوم النقابات المهنية المختلفة بتوظيف كل ما تمتلكة من إمكانات مادية ويشرية من أجل العمل على سد الفجوة الرقمية لاى أعضائها بصفة عامة و لاى الباحثين التريويين بصفة خاصة ، و ذلك بعقد دورات تدريبية و محاضرات و غيرها . ץ- أن تقوم الأحزاب السياسية المختلفة بالمساهمة في سد الفجوة الرقمية لدى الباحثين التريويين و ذلك باستغلال كل ما لايها من أماكن و قرات بشرية و مادية. r- أن تقوم الجمعيات الخيرية الموجودة في المجتمع بعمل مكتبات و أماكن لخدمة الباحثيين مزودة بأجهزة حاسب آلي و انترنت من أجل خدمة الباحثين التريويين و سد الفجوة الرقمية

$$
\text { لديهم بتدريبهم على استخدامها و تويظفها في البحث التريوي • }
$$

ع - أن تسهم وزلاة الاتصالات في سد الفجوة الرقمية لاى المواطنين و خاصة الباحثين عن طريق استغلال ما لايها من قرات و متخصصين في مجال الاتصالات و تكنولوجيا المعلومات وذلك بعقد دورات تدريبية على استخدام الإنترنت و الحاسب الآلي و توظيفهم في خدمة البحث العلمي بشكل صحيح و سريع • 


\section{تصور مقترح لسد الفجوة الرقمية لدى الباحثين التربويين كمدخل لتطوير المعرفة التربوية.}

ه- يمكن ان تقوم مؤسسات المجتمع المدني سابقة الأكر بالإضافة لتدريب الباحثين على توظيف تكنولوجيا العصر الرقمي في الحصول على المعارف و المعلومات وأن تقوم بتعريفهم بكيفية الحفاظ على حقوق ملكيتهم الفكرية عند التعامل مع العالم الرقمي ، و كذلك أهم الأخلاقيات التي يجب أن يتسلحوا بها أثناء أخذ المعلومات و الحصول عليها من الإنترنت مثل الأمانة العلمية و المحافظة على حقوق الآخرين و توثيق المعلومات بدقة تامة و البعد عن السرقات العلمية بكل أشكالها ـ خامساً: الضمانات اللازمة لنجاح سل الفجوة الرقمية لدى الباحثيز التربويين كمدخل لتطوير المعرفة التزبوية .

حتى يتم تنفيذ و تطبيق التصور المقترح للاراسة الحالية على أرض الواقع لابد من توفر مجموعة من الضمانات اللازمة لتنفيذه و نجاحه و أهمها ما يلي : 1- ضرورة قيام أعضاء هيئة التدريس بكليات التربية و إدارات كليات التربية و كل العاملين بها بتحويل التصور المقترح إلى إجراءات تنفيذية على أرض الواقع . ץ- ضرورة توفير البنية التحتية داخل الجامعات المصرية و كليات التربية من أجل المساعدة على سد الفجوة الرقمية لاى الباحثين التربويين و ذلك بتوفيرها لهم بالمجان

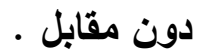

ץ- ضرورة تبني متخذي القرار في مصر و المشاركين في وضع السياسات التعليمية في مصر لقضية سد الفجوة الرقمية لدى الباحثين بصفة عامة و الباحثين التريويين بصفة

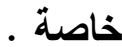
ع - أن تتيح الدولة الأجهزة التكنولوجية الحديثة و كذلك شبكة الإنترنت بسعر معقول يتناسب مع الاوضاع الاقتصادية للباحثين التريويين حتى تسهل عليهم عملية اقتنائها و الاستفادة منها . (- n ه- أن يتم وضع خطة استراتيجية داخل الجامعات المصرية و داخل كليات التربية لتطوير بنيتها التحتية وتحسينها وتطويرها بشكل مستمر بتلك الجامعات بصفة عامة و بكليات 
تصور مقترح لسد الفجوة الرقمية لدى الباحثين التربويين كمدخل لتطوير المعرفة التربوية.

التربية بصفة خاصة من أجل المساعدة على الوصول الرقمي و سد الفجوة الرقمية لاى

الباحثين التربويين البين

צ- أن تشكل كليات التربية لجنة من المتخصصين في تكنولوجيا المعلومات لمتابعة تحسن مستوى الباحثين التريويين و تقييمه بشكل مستمر حتى تضمن في النهاية سدالفجوة الرقمية لايهرم .

- V نشر الوعي بين الباحثين التريويين بأهمية سد الفجوة الرقمية لديهم و مدى الفائدة التي ستعود عليهم من ذلك و التي ستعود على تظوير المعرفة التربوية في المجتمع · 


\section{مراجــع الدراسة :}

\section{أولا : المراجع العربية: - و}

1. أبو بكر محمود الهوش (rا.بr) ، أدوات البحث عن المطلومات في البيئة الرقية ، القاهرة: دار السحاب للنشر و التوزيع. r. أحمد محمد رجائي الرفاعي (·(ب) ) "المعرفة التربوية : ورقية أم إلكترونية (الدوريات

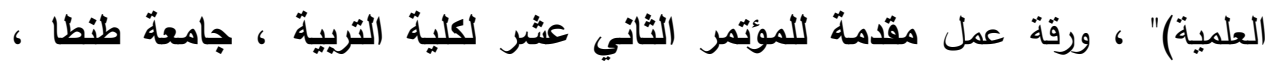
والمعنون بـ "حال المعرفة التريوية المعاصرة: مصر نمونجًا"، المنعقد بكلية التربية ،

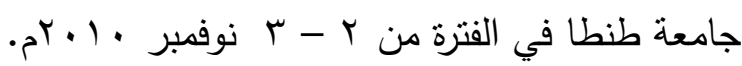

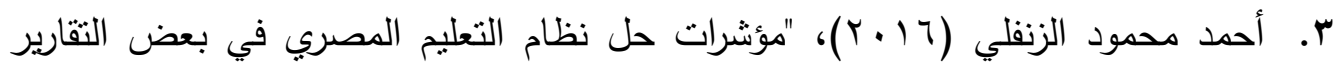

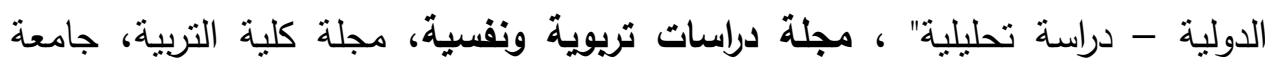

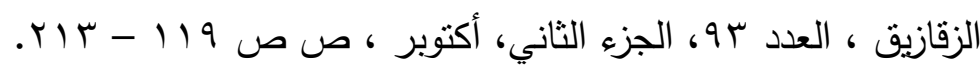

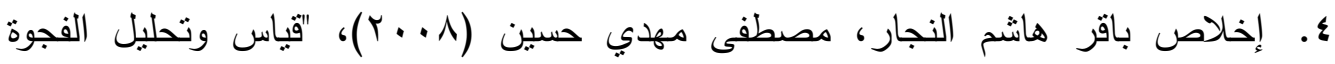
الرقمية في الوطن العربي، مجلة العلوم الاقتصادية، العراق، المجلد 7 ، العدد بrا، يوليو ،

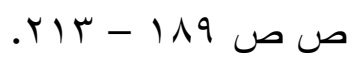

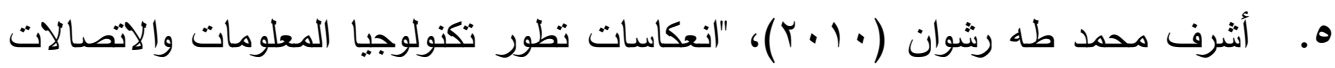

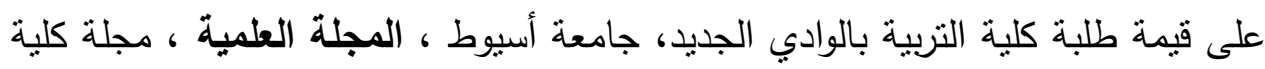

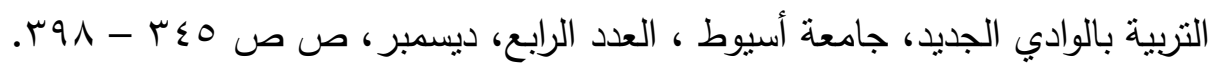

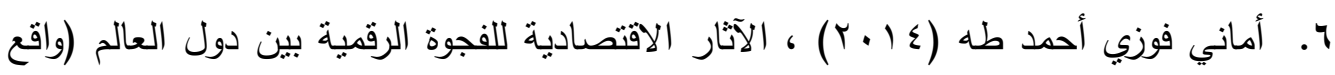
الفجوة الرقمية بين الدول النامية والدول المنقدمة"، المجلة العلمية للاقتصاد والتجارة، مجلة التحانة

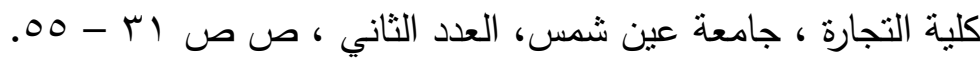

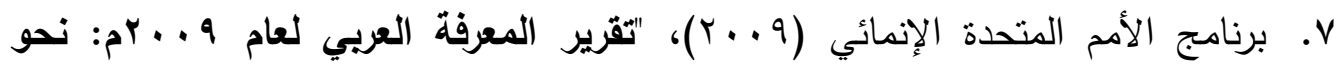
تواصل معرفي منتج" ، دبي: مؤسسة محمد بن راثد آل مكتوم والمكتب الإقليمي للادول العربية بالتعاون مع برنامج الأمم المتحدة الإنمائي.

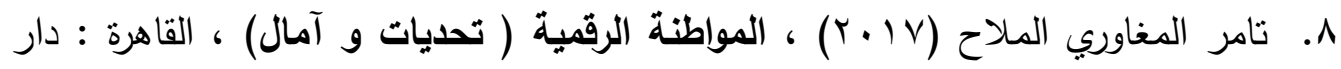

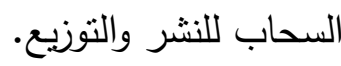


9. جمال على الدهثان (ع ( • ب)، "ملامح رؤية مقترحة للارتقاء بالبحث التربوي العربي" ، ورقة عمل مقدمة للمؤتمر العلمي الثامن (الدولي الخامس)، المعنون بـ "الإنتاج العلمي لمئه

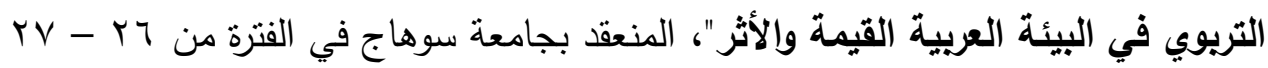

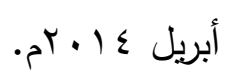

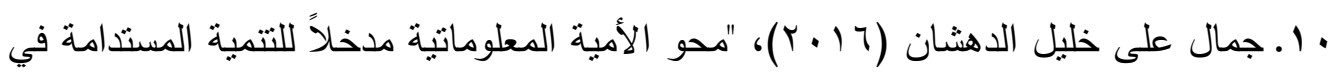
العصر الرقمي "بحث مقدم للمؤتمر العلمي السنوي الرابع عشر: من تعليم الكبار إلى الى

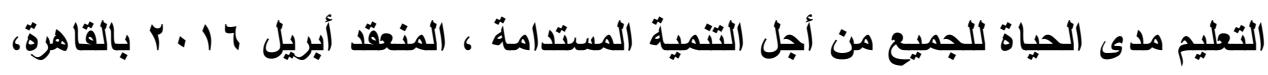
مركز تعليم الكبار بجامعة عين شمس.

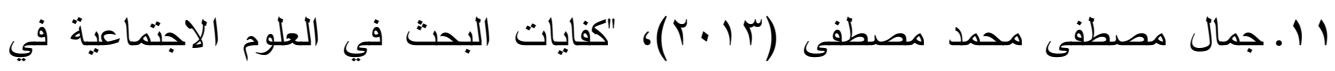

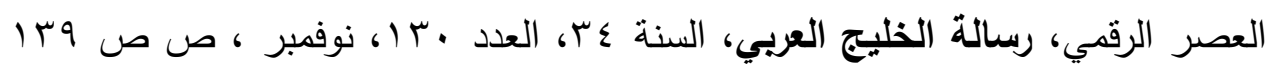
$.1 \vee 9-$

r ا. حسن إبراهيم عبد العال ( • ( ب)، "التقريز الختامي لمؤتمر كلية التربية - جامعة طنطا

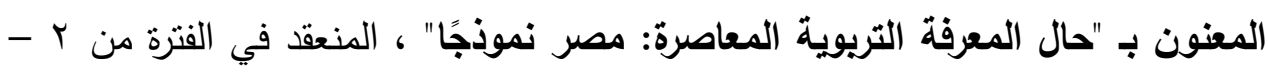

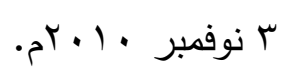

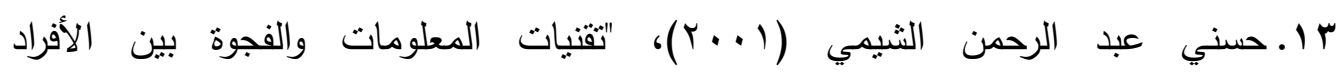
والمجتمعات"، دراسة عربية في المكتبات وعلم المعلومات، المجلد ج ، العدد الأول، يناير

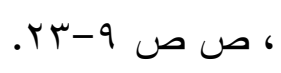

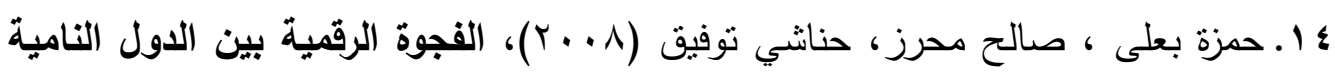

والمتقدمة، كلية العلوم والاقتصادية والتيسيير ، جامعة الحاج لخضر باجئ بالجزئر .

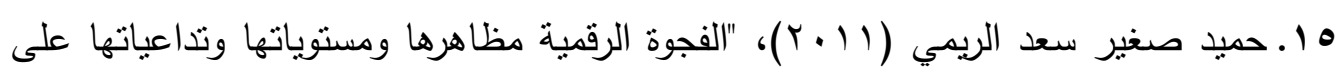

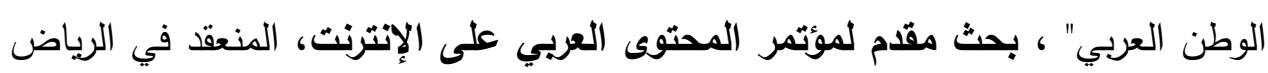

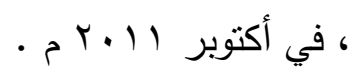

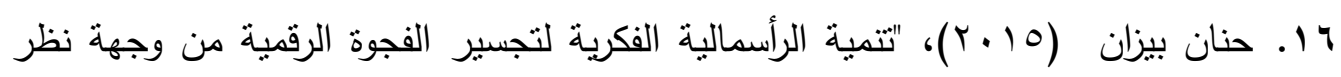

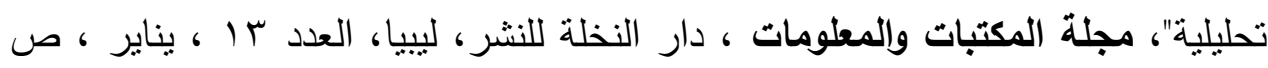

$$
\text { ص O - ט }
$$




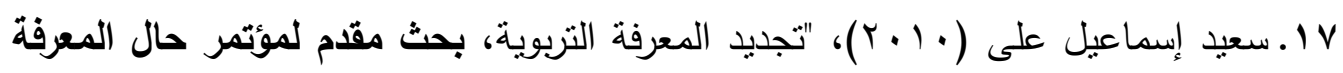

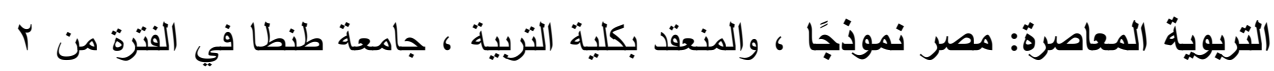

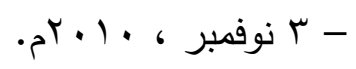

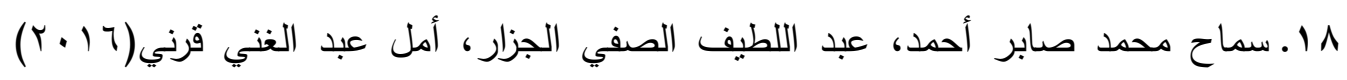
،"استراتيجيتا التعلم الفردي والتعلم التعاوني ببرامج التعلم القائمة على الويب- هل يوجد أثز

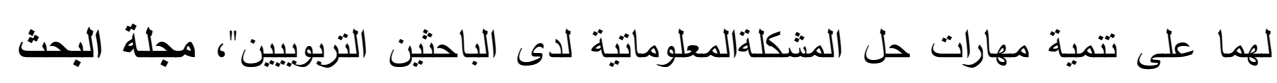

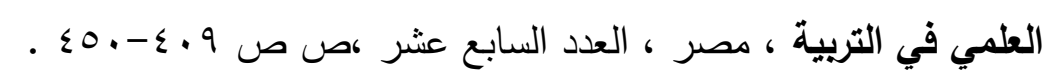

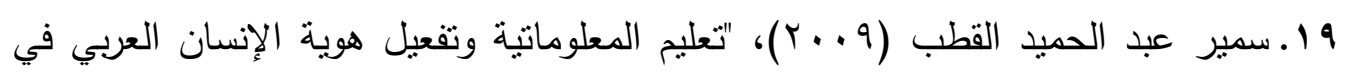
مجتمع المعرفة- تصور مقترح "، بحث مقدم بمؤتمر توظيف المعلوماتية في ثقافة

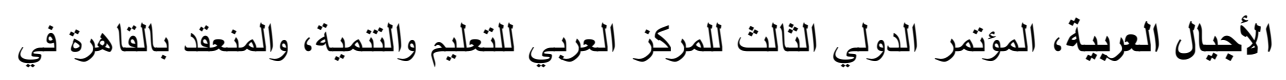

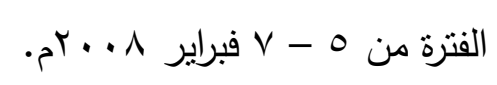

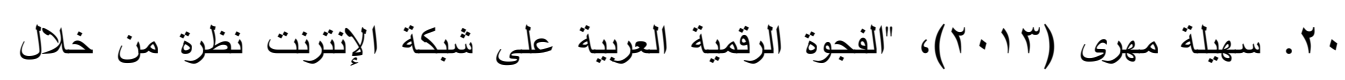

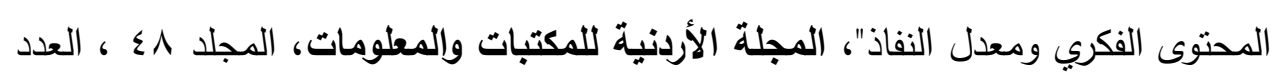

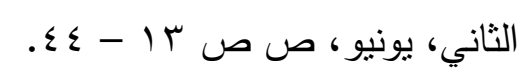

ا.Y.صلاح الدين محمد توفيق (10 ب ب)، "ثقافة تربية الطفل العربي في العصر الرقمي (الواقع

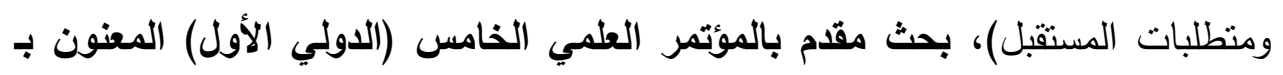

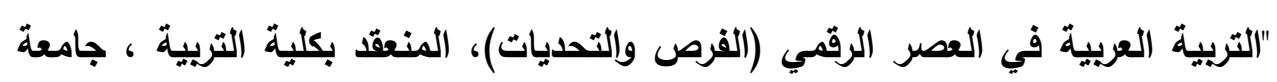

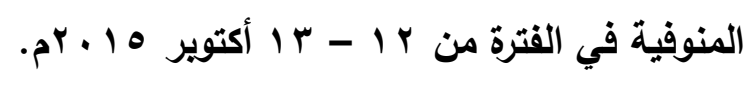

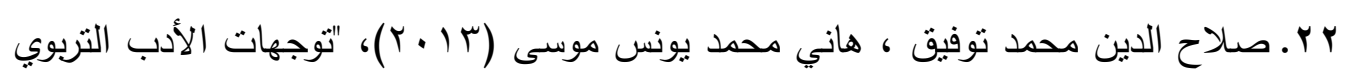

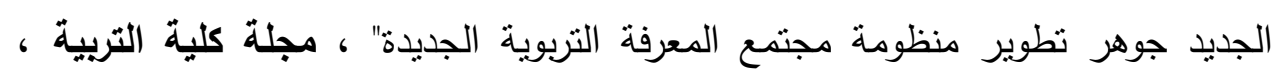

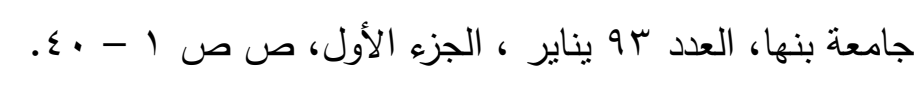

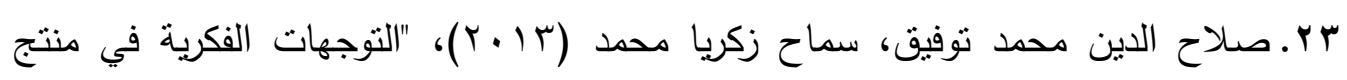
المعرفة التربوية المعاصرة لمجلة كلية التربية - جامعة بنها (دراسة في فاعلية التأصبل

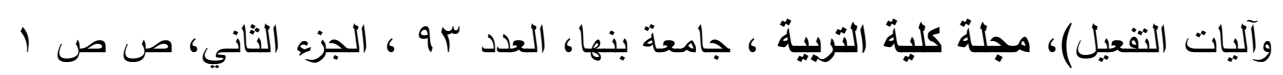




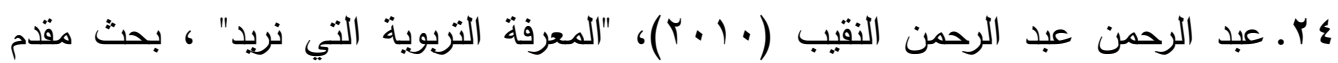
للمؤتمر المعنون بـ "حال المعرفة التريوية المعاصرة: مصر نموذجًا" ، المنعقد بكلية التربية

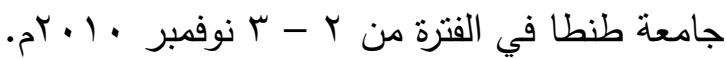

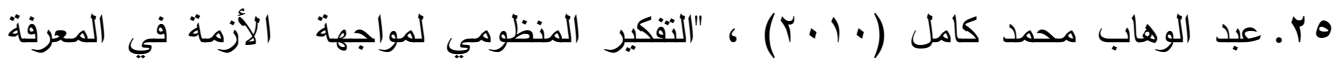
التربوية"، بحث مقدم لمؤتمر حال المعرفة التريوية المعاصرة: مصر نموذجًا ، والمنعقد

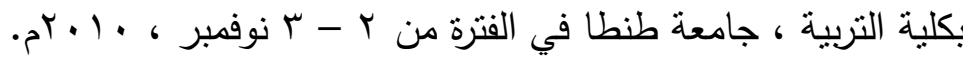

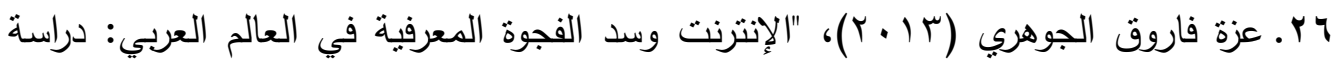
استطلاعية عن توجهات القراءة في بيئة الإنترنت ودورها في بناء مجتمع المعرفة، مجلة

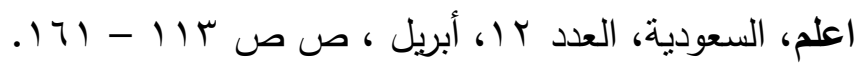

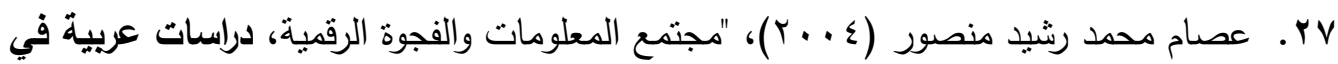

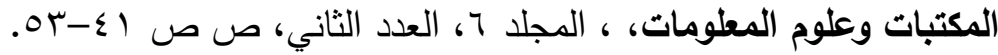

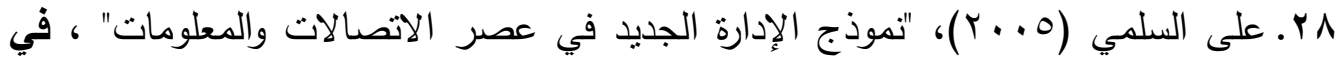
رحلتي مع الإدارة: كتابات إدارية في قضايا وطنية، الجزء الثاني، القاهرة: دار غريب الإداب للنشر

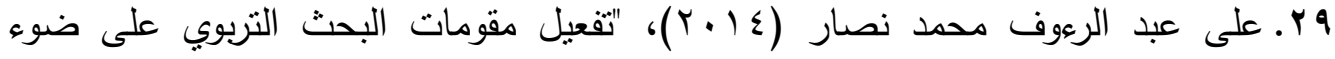

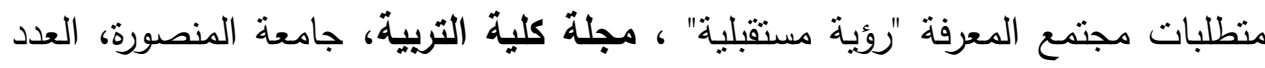

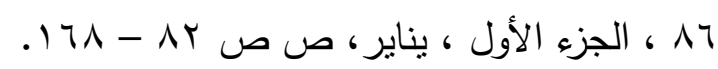

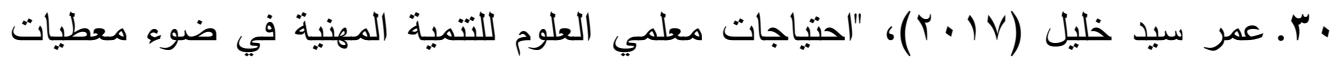
العصر الرقمي" ، بحث مقدم للمؤتمر العلمي التاسع عشر للجمعية المصرية للتربية

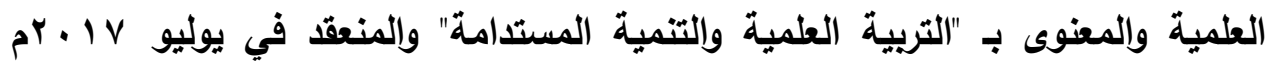
بالقاهرة، الجمعية المصرية للتربية العلمية. اب. فاتن عبد المجيد السعودي فودة (• ( • ب)، "مدخل تحسين الجودة المستمر "روية لتطوير

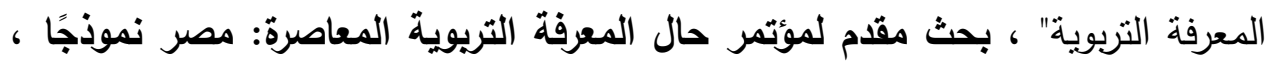

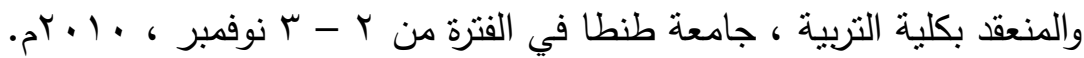


r r. فاطمة بنت عبد الله آل معجب (T 1 ا ب)، "الفجوة الرقمية لدى طلاب كلية التربية بجامعة

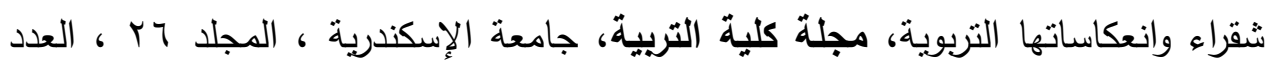

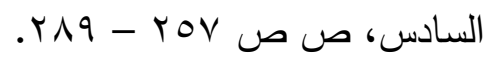

r r. فاطمة رمضان عوض النجار (10 ب r) ، "استراتجيية مقترحة لتتمية كفايات البحث العلمي لاى طلاب الدراسات العليا في ضوء متطلبات اقتصاد المعرفة"، مجلة كلية التربية،

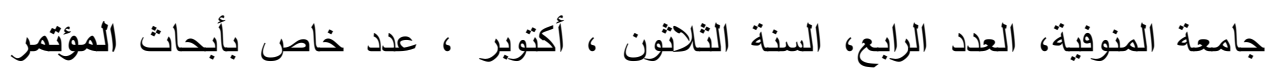

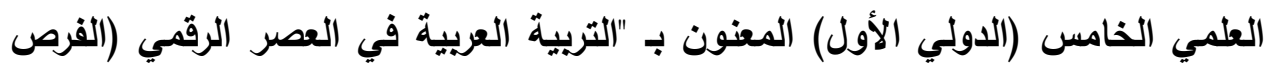

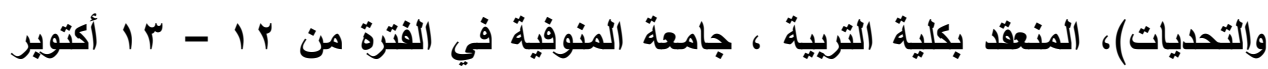

$$
\text { 10 } 10
$$

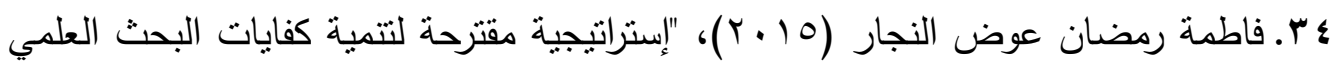

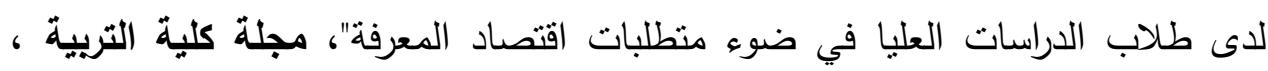
جامعة المنوفية، العدد الرابع، السنة الثلاثون ، أكتوبر، عدد خاص بحوث فئوث المؤتمر العلمي الخامس (الدولي الأول) ، التربية العربية في العصر الرقمي (الفرص والتحديات) ، المقام

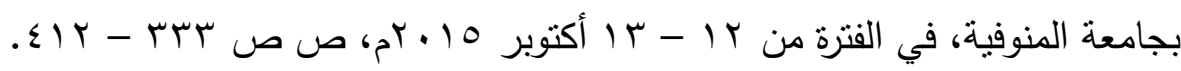
هr. فؤاد أبو الحطب و أما ل صادق(199 1 م ) ) ، مناهج البحث و الطرق التحليل الإحصائي في العلوم النفسية و التريوية و الاجتماعية ، القاهرة : مكتبة الانجلو

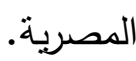

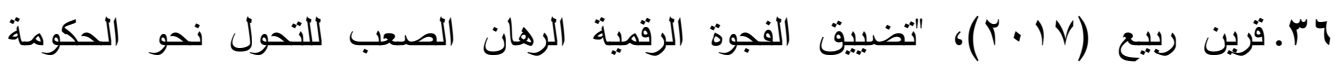

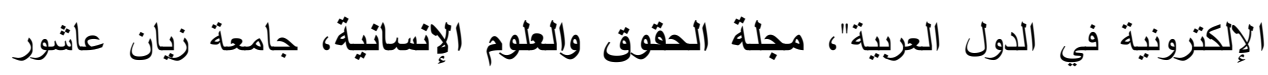

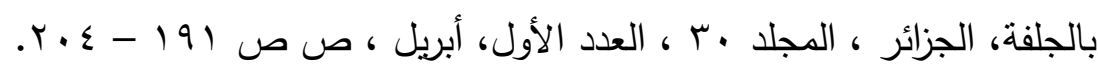

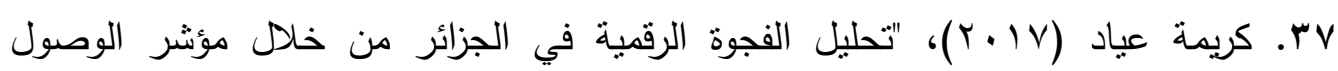

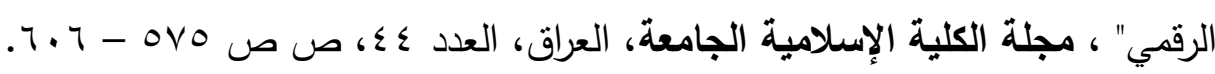

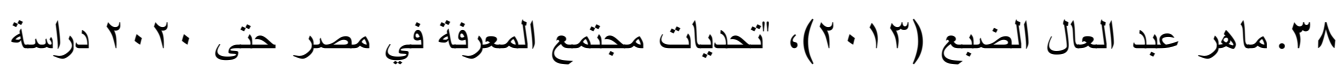

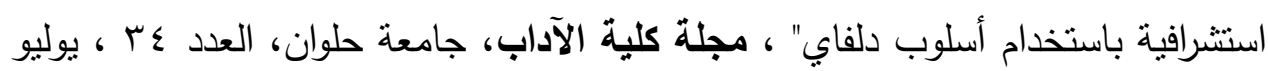

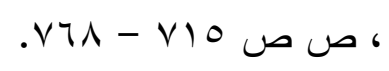




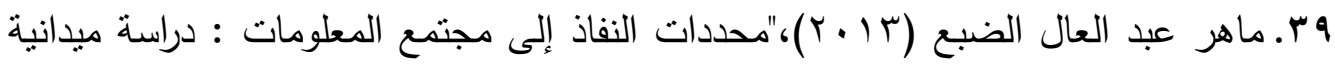

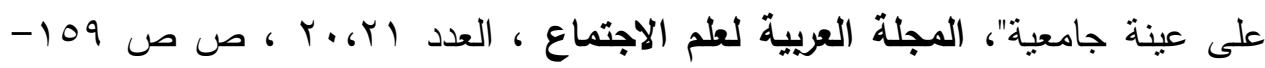
. INE

• ـ. مجدي صلاح طه المهدي (10 (10)، "الأخلاقيات البحثية في زمن الرقمية (دراسة تحليلية)" ، بحث مقدم بالمؤتمر العلمي الخامس (الدولي الأول) المعنون بـ "التربية

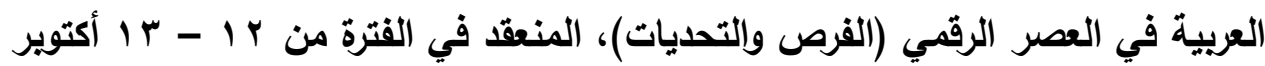
10

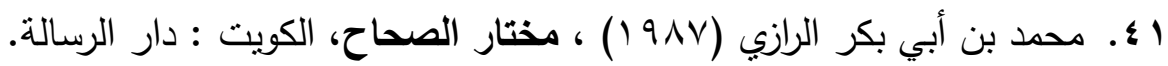

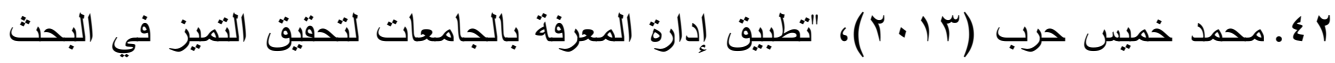

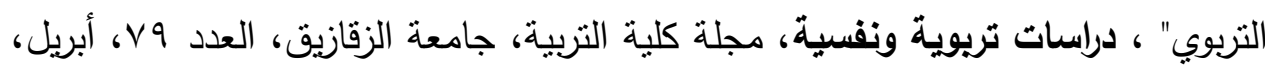

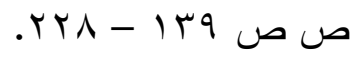

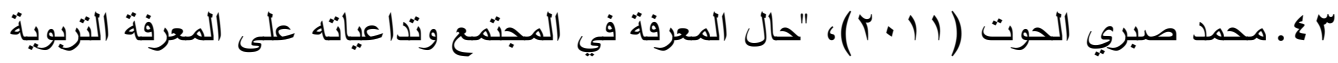
"، مجلة دراسات تريوية ونفسية، مجلة كلية التربية ، جامعة الزقازيق ، العدد سعل،

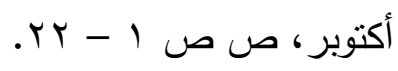

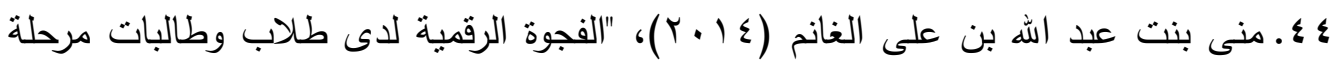

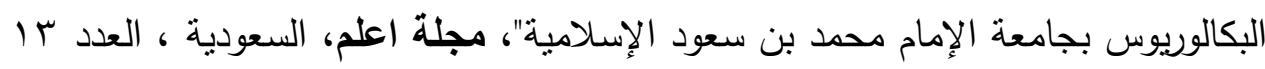

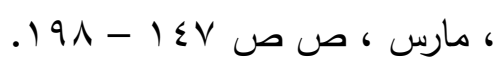

ه ـ ـ مهني محمد إبراهيم غنايم (10 • ب)، "الإصلاح التربوي العربي في العصر الرقمي ضرورة

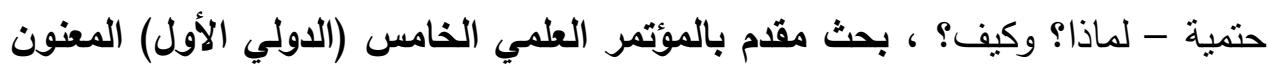

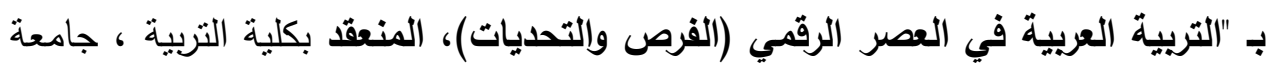

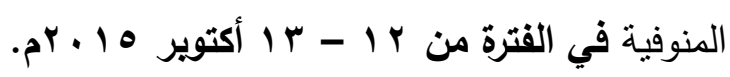

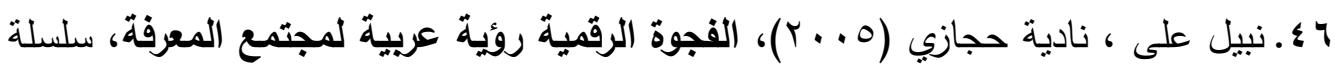
عالم المعرفة، الكويت: المجلس الوطني للنقافة والفنون والآداب.

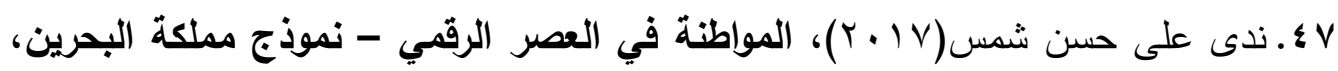
معهد البحرين للتتمية السياسية. 


$$
\text { تصور مقترح لسد الفجوة الرقمية لدى الباحثين التربويين كمدخل لتطوير المعرفة التربوية. }
$$

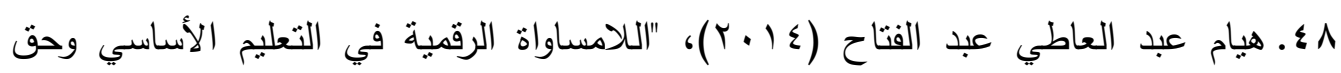
التعليم في الحياة، رسالة دكتوراه، معهد الدراسات التربوية ، جامعة القاهرة.

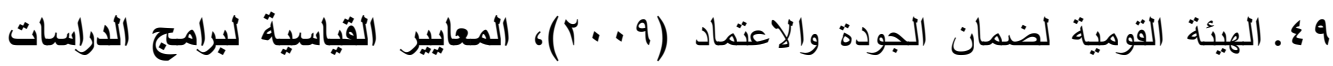
العليا، إصدارات الهيئة القومية لضمان الجودة والاعتماد، القاهرة: الهيئة القومية لضمان

$$
\text { ثانيا : المراجع الأجنبية: }
$$

50. Barzilai - Nahon, K. (2006), "Gaps and Bits: Conceptualizing Measurements for Digital Divide/s", The Information Society, vol. 22, pp. $269-278$.

51. Berrio_zapata, C. \& Rojas, H. (2014), "The Digital Divide in the university: the Appropriation of ICT in Higher Education Students from Bogota, Colombia", Comunicar, Media Education Research Journal, Vol.XXII, No. 43, pp. 133 - 142.

52. Capraro, R. M. \& Thompson, B. (2008), "The Educational Researcher Defined: What will future Researchers Be trained to Do?, The Journal of Educational Research, vol. 101, No. 4, pp. 247 253.

53. Chen, W. \& Wellman, B. (2004), "The Global Digital Divide within and between countries", IT \& Society, vol. I , issue 7, pp. $18-25$.

54. Cruz - Jesus, F., Vicente, M. R., Bacao, F. \& Oliveira, t. (2016), "the Education - Related Digital Divide: an analysis for the fu 28", Computers in Human Behavior, vol. 56, pp. $72-82$.

55. Delandshere, G. (2004), "The moral, social and political Responsibility of Educational Researchers: Resisting the current Quest for certainty “, International Journal of Educational Research, vol. 41, pp. $237-256$.

56. Diezmann, C.M. (2005), "Growing Scholarly Teachers and Educational Researchers: A curriculum for a Research pathway in Preservice Teacher Education", Asia- pacific Journal of Teacher Education, vol. 33, No. 2, July, pp. $181-193$. 
تصور مقترح لسد الفجوة الرقمية لدى الباحثين التربويين كمدخل لتطوير المعرفة التربوية.

57. Fuchs, C. \& Horak, E. (2008), Africa and the Digital Divide", Telematics and Informatics, vol. 25, pp. $99-116$.

58. Halili, S. H. \& Sulaiman, H. (2018), "Factors influencing the Rural Students' acceptance using ICT for Educational purposes", Kasetsart Journal of social sciences, In press, pp. $1-6$.

59. Herselman, M. \& Britton, K. G. (2002), "Analysing the Role of ICT in bridging the Digital Divide a mongst Learners", South African Journal Education, vol. 22, No. 4, pp. 270 - 274.

60. Judge, S. , Puckett, K. \& Meebell, S. (2006), "Closing the Digital Divide: update from the early childhood - Longitudinal Study", the Journal of Educational Research, vol. 100, No. 1, pp. 52 60 .

61. Kerdeman, D. (2015), "Preparing Educational Researchers: The Role of self-Doubt”, Educational Theory, vol. 65, No. 6, pp. 719 -738 .

62. Khalid, Md. S. \& Pedersen, M. J. L. (2016), "Digital Exclusion Higher Education context: A systematic Literature Review”, Procedia - Social and Behavioral Sciences, vol. 228 , pp. $614-621$.

63. Korupp, S. E. \& Szydlik, M. (2005), "Causes and Trends of the Digital Divide”, European Sociological Review, vol. 21, No. 4, pp. $409-422$.

64. Lai, K. W. , Voogt, J. , Knezek, G. \& Gibson, D. (2016), “EDU summit: A global Knowledge Building Community for Educational Researchers practitioners, and policy Makers", Educational Technology \& Society, vol. 19, No. 3, pp. 5 - 15.

65. Mcphail, T. L. (2009), Development Communication: Reframing the Role of Media, United Kingdom: Black well Publishing LTD.

66. Naidoo, S. \& Raju, J. (2012), "Impact of the Digiatl Divide on Information Literacy Training in Higher Education Context", SA Jn Libs \& Inf sci, vol. 78, No. I, pp. $34-44$. 
تصور مقترح لسد الفجوة الرقمية لدى الباحثين التربويين كمدخل لتطوير المعرفة التربوية.

67. Pena-Lopez, I. (2010), "from Laptops to competences: Bridging the Digital Divide In Education", (RUSC (Revista de Universidady Sociedad delconocimiento), vol. 7, No.1, pp. $21-32$.

68. Rao, S. S. (2005), "Bridging Digital Divide: Efforts in India", Telematics and Informatics, vol. 22, pp. $361-375$.

69. Rodrigo, M. M. T. (2005), "Quantifying the Divide : A comparison of ICT Usage of schools in Metro Manila and IFA - Surveyed Countries", International Journal Educational Development, Vol. 25, pp. $53-68$.

70. Rutten, P. \& Poel, M. (2002), Digital infrastructure, Amsterdam: Ruthenium Institute.

71. Schooman, D. (2017), "Conceptualizing the Role of an Educational researcher: A critical Multicultural Educator's perspective", Critical Questions in Education, (special issue), vol. 8, No. 2, pp. 116 - 137.

72. Smith,K\& Harvey, R. (2006), Is There a role for Professional Associations in fostering Research ? In Khoo, C. , Singh, Q \&Chaudhry, A.s. , Proceedings of the Aisa-Pacific Conference on Library \& Information Education \& Practice (A-LIEP), Singapore, 3-6 April , 2006.

73. Tien, F.F\& Fu, T. - T. (2008), "the correlates of the Digital Divide and their Impact on College Student Learning", Computers \& Education, vol. 50, pp. $421-436$.

74. Warschauer, M. (2003), "Dissecting the Digital Divide: A case study in Egypt", The Information Society, vol. 19, pp. 297 - 304.

75. Whitehead, J. (2010), “As an Educator and Educational Researcher, How do I improve what I am Doing and Contribute to Educational theories that carry Hope for the future of the humanity?", i.e. : inquiry in Education, vol. 1. ISS: 2, Article 2, pp. $1-15$.

76. World Bank (2014), Development, Research and Knowledge society, Washington: The World Bank Group. 